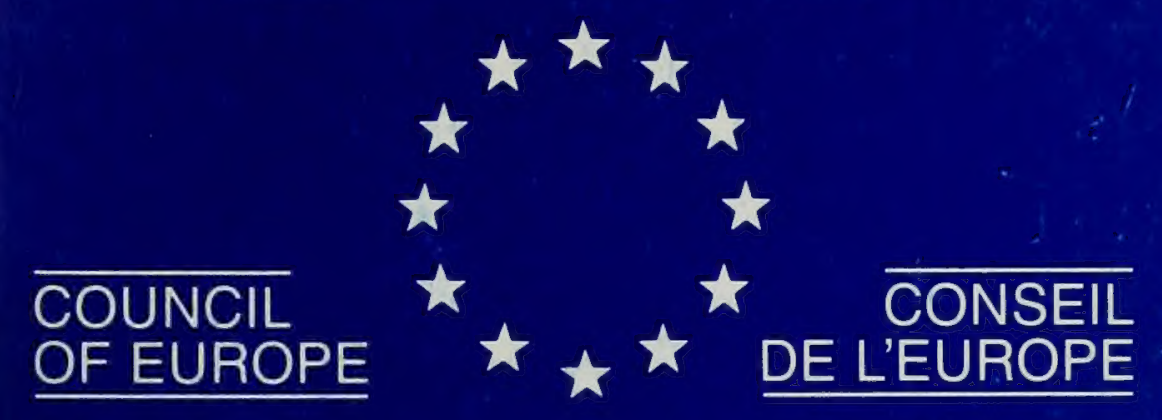

Marine turtles in the Mediterranean:

Distribution, population status, conservation 
A/N 362

Speciés/Animals

Bern. Conv'/NaE 


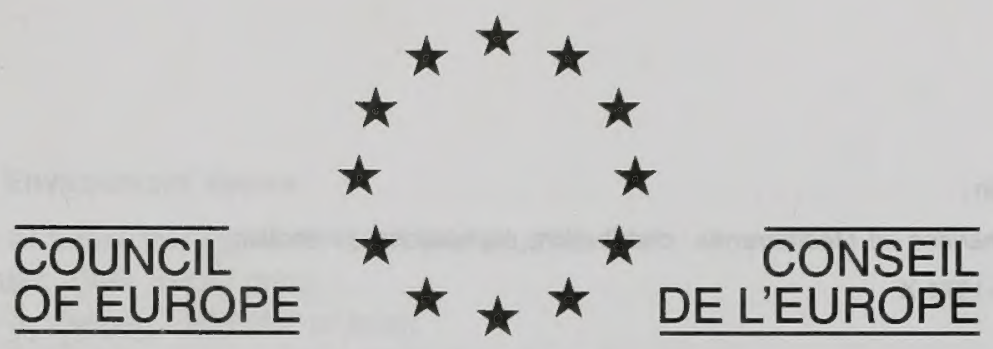

Convention on the Conservation of European Wildlife and Natural Habitats

\title{
Marine turtles in the Mediterranean: distribution, population status, conservation
}

\author{
by Brian Groombridge \\ World Conservation Monitoring Centre \\ 219c Huntingdon Road, Cambridge CB3 ODL \\ United Kingdom
}

A report to the Council of Europe Environment Conservation and Management Division 
French edition:

Les tortues marines en Méditerranée: distribution, populations, protection ISBN 92-871-1871-X

Strasbourg, Council of Europe, Publishing and Documentation Service ISBN 92-871-1864-7

(C) Copyright, Council of Europe, Strasbourg, 1990

Printed in France 


\section{Nature and Environment Series}

1. Aspects of forest management, 1968 (out of print)

2. Freshwater, 1968 (out of print)

3. Animals in danger, 1969 (out of print)

4. A handbook for local authorities, 1971 (out of print)

5. Soil conservation, 1972 (out of print)

6. Endangered Alpine regions and disaster prevention measures, 1974

7. Air pollution problems - Manual of experiments, 1975

8. Evolution and conservation of hedgerow landscapes in Europe, 1975

9. The integrated management of the European wildlife heritage, 1975

10. Threatened mammals in Europe, 1976 (out of print)

11. The effects of recreation on the ecology of natural landscapes, 1976 (out of print)

12. Heathlands of western Europe, 1976 (out of print)

13. The degradation of the Mediterranean maquis, 1977 (published jointly with Unesco)

14. List of rare, threatened and endemic plants in Europe, 1977 (out of print)

15. Threatened amphibians and reptiles in Europe, 1978 (out of print)

16. Vegetation map (scale 1:3000 000) of the Council of Europe inember states, 1979

17. Model outline environmental impact statement from the standpoint of integrated management or planning of the natural environment, 1980

18. Threatened freshwater fishes of Europe, 1980

19. European peatlands, 1980

20. Behaviour of the public in protected areas, 1981

21. Dry grasslands of Europe, 1981

22. Alluvial forests in Europe, 1981

23. Threatened Rhopalocera (butterflies) in Europe, 1981

24. Birds in need of special protection in Europe, 1981

25. Inventory and classification of marine benthic biocenoses of the Mediterranean, 1982

26. Town farms, 1982

27. List of rare, threatened and endemic plants in Europe (1982 edition), 1983

28. Nature in cities, 1983

29. The vegetation of the Alps, 1983

30. Salt marshes in Europe, 1984

31. Protected marine areas, 1985

32. European dune and shoreline vegetation, 1985

33. Ecological repercussions of constructing and using ski-runs, 1986

34. Environmental education for the farming community - Experimental schemes in Europe, 1987

35. Invertebrates in need of special protection in Europe, 1987

36. Development of flora and fauna in urban areas, 1987

37. Conservation of marine benthic biocenoses in the North Sea and the Baltic, 1987

38. The protection of dragonflies (Odonata) and their biotopes, 1988

39. Problems of soil conservation, 1988

40. Texts adopted by the Council of Europe in the field of the conservation of European wildife and natural habitats, 1989

41. The biology, status and conservation of the monk seal (Monachus monachus), 1989

The opinions expressed in these publications are those of the authors and do not necessarily reflect the views of the Council of Europe. 
42. Saproxylic invertebrates and their conservation, 1989

43. Possible causes of forest decline and research programmes in Europe, 1989

44. The biological significance and conservation of Hymenoptera in Europe, 1990

45. Status, conservation needs and reintroduction of the lynx (Lynx lynx) in Europe, 1990

46. Conservation of threatened freshwater fish in Europe, 1990

47. Status and conservation needs of the wolf (Canis lupus) in the Council of Europe member states, 1990

48. Marine turtles in the Mediterranean: distribution, population status, conservation, 1990

\section{Environmental encounters series}

1. Environmental training in agricultural circles, 1987

2. Parks, plans and people - protected areas and socio-economic development, 1987

3. Workshop on the situation and protection of ancient natural and semi-natural woodlands in Europe, 1987

4. A new management of the environment in rural areas, 1988

5. Training course for managers of protected areas in Europe and Africa, 1989

6. Workshop on the situation of the brown bear (Ursus arctos) in Europe, 1989

7. Nature tomorrow, 1989

8. Colloquy on genetic heritage, the conservation of wild progenitors of cultivated plants, 1990

9. Seminar on nature museums: tools for learning about, promoting and protecting the natural heritage of Europe, 1990

\section{Planning and Management Series}

1. Hedges, 1988

2. Farming and wildlife, 1989 


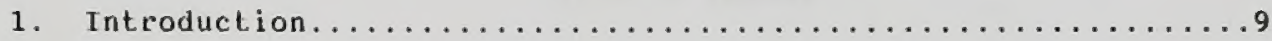

2. Summary and Reconunendations

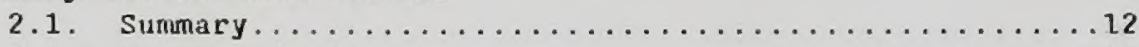

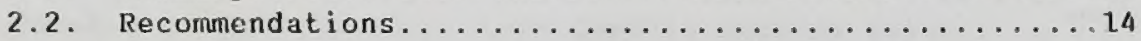

3. Nesting siles and species

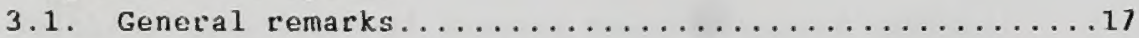

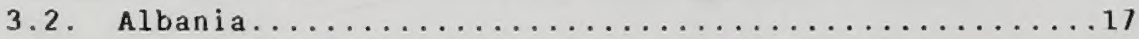

3.3. Algeria........................

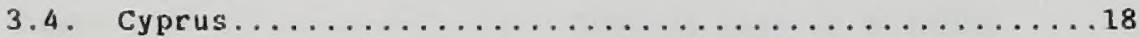

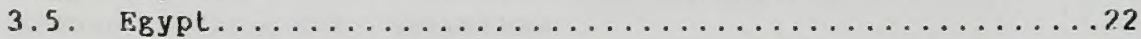

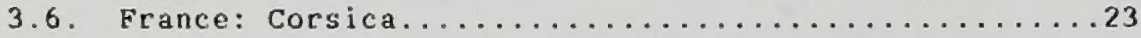

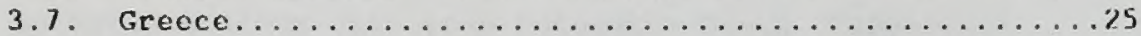

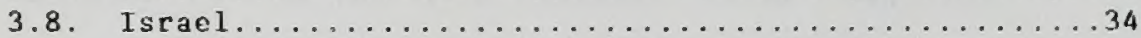

3.9. Italy . . . . . . . . . . . . . . . . . . . . . . . . .

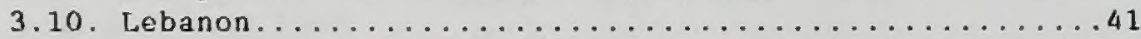

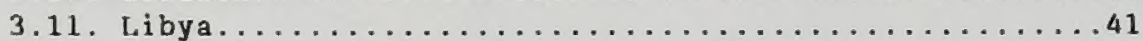

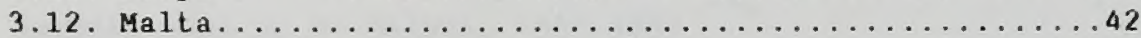

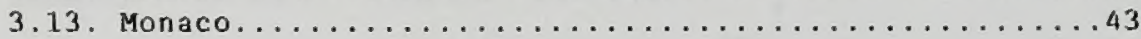

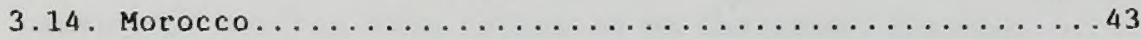

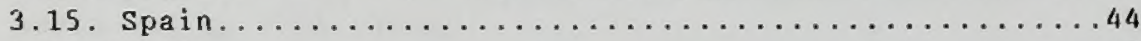

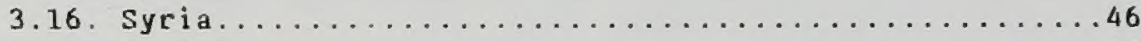

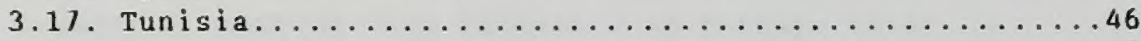

3.18. Turkey. . . . . . . . . . . . . . . . . . . . . . . . . . . . 48

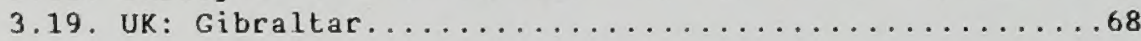

3.20. Yugoslavia..............................69

4. Mediletranean nesting populations

4.1. The origin of Mediterranean populations........... 0

4.2. Nesting population size and trends: a comparison.....70

4.3. Threats to nesting populations................ 44

5. Turtiles at sea

5.1. Interchange between the Mediterranean and Atlantic...17

5.2. Turtle movements within the Mediterranean.........78

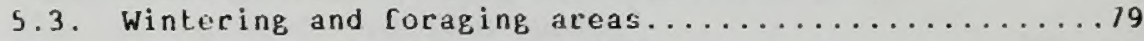

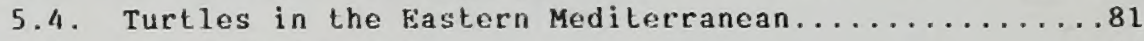

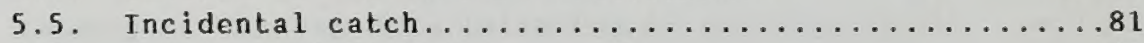

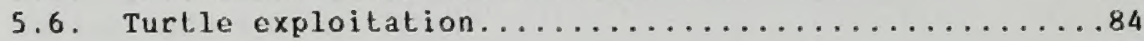

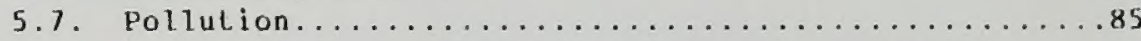

6. Non-nesting and occasional species

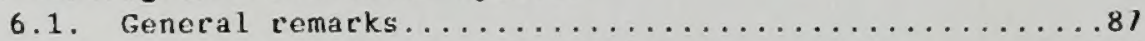

6.2. Leatherback Dermochelys coriacea................87

6.3. Hawksbill Eretmochelys imbricata...............88

6.4. Kemps Ridley Lepidochelys kempi.................89

6.5. Olive Ridley Lepidochelys olivacea..............89

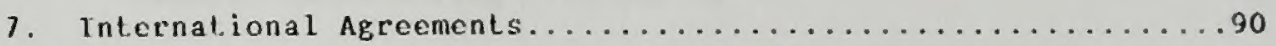

8. Acknowledgements.............................. 92

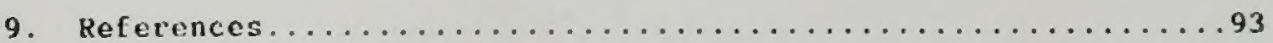


Digitized by the Internet Archive in 2010 with funding from UNEP-WCMC, Cambridge 


\section{LIST OF TABLES}

Table 1. Sumary of selected data from Caretta and Chelonia nesting sites in Cyprus

Table 2. Summary of selected data from Caretta nesting sites in Greece

Table 3. Relative importance of nesting beaches around laganas Bay, Zakynthos

Table 4. Summary of selected data from caretta nesting beaches around Laganas Bay, Zakynthos

Table 5. Selecled nesting data from Potamakia beach, Cephalonia

Table 6. Turtle emergence and nesting data, Dalyan Beach, 4 June 5 July 1987

Table 7. Caretta nesting at Dalyan, 1987-1989

Table 8. Summary of nesting data collected on Sarigerme-Dalaman beach during 1988 survey

Table 9. Summary of nesting data collected on vethiye-calis north beach during 1988 survey

Table 10. Sumnary of nesting data collected on Patara beach during 1988 survey

Table 11. Summary of nesting data collected on Finike-Kumluca beach during 1988 survey

Table 12. Summary of selected nesting data collected on the Belek coast between Antalya and Side during 1988 survey

Table 13. Summary of selected nesting data collected in the Kizilot region during 1988 survey

Table 14. Summary of nesting data collected on Demictas beach during 1988 survey

Table 15. Summary of nesting data collected on Gazipasa Ciftlik beach during 1988 survey

Table 16. Summary of nesting data collected at Göksu Delta during 1988 survey

Table 17. Summary of selected nesting data collected at Kazanli beach during 1988 survey

Table 18. Summary of selected nesting data collected at Akyatan beach during 1988 survey 
L.TST OF TABLES (cont.)

Table 19. Summary of selected nesting data collected at Samandagi beach during 1988 survey

Table 20. Selected nesting data collected in south-east Turkey (Cukurova Delta and coast of Gulf of Iskenderun), 1988

Table 21. Summary of selected nesting data collected in south-east Turkey (Cukuruva Delta and coast of Gulf of Iskenderun) between 25 May and 16 August 1988

Table 22. Summary of size and trend of known past and present Loggerhead Caretta caretta nesting populations in the Mediterranean

Table 23. Summary of size and trend of known past and present Green Turtle Chelonia mydas nesting populations in the Medilerranean

Table 24. Estimates of total number of females nesting each year in the Mediterranean

Table 25. Provisional estimates of the number of turtles killed by fishing operations in the Western Mediterranean, based on interviews conducted in 1978 by R. Argano

Table 26. Summary of current annual turtle catch in the Mediterranean

Table 27. Summary of historical conmercial turtle harvest in the Mediterranean at known major sites

Table 28. Major International Agrecments affecting marine turtles in the Mediterranean, and Party states thereto 


\section{INTRODUCTION}

This report, which covers the conservation status and geographical distribution of marine turtles, their nesting beaches and foraging areas in the Mediterranean, was prepared under Contract No. 32.88 from the Environment Conservation and Management Division within the secrelariat General of the Council of Europe. The first draft document incorporated information available up to 5 December 1988. This draft was revised in March 1990, to incorporate review comments and previously unavailable information from fieldwork undertaken during the 1988 season.

The report is essentially a review ducument; emphasis has been placed on gathering and summarising the available information relating to marine turtles in the Mediterranean, with the intention of providing a base-line by which future conditions may better be assessed.

Most attention is given to the two species (Caretta caretta and Chelonia mydas) known to nest regularly and in significant numbers in the Mediterranean. Cost-cfective research and realistic conservation measures can be designed for these species, whereas this is not so for the rare, occasional or accidental species that also occur in the Mediterranean but do not nest. This group comprises Dermochelys coriacea (which may nest irregularly), Eretmochelys imbricata and Lepidochelys kempi. All five are recognised as globally threatened species, the Loggerhead is ranked "Vulnerable", the remainder "Endangered" (IUCN, 1988).

The work covers the Mediterranean sea only; the Black sea is excluded. General aspects of the ecology, population biology and conservation of sea turtles are not discussed: much information on these topics, and citations of further literature, can be found in Bjorndal (1982), Mrosovsky (1983), Groombridge (1982), and Groombridge and Luxmoore (1989). Laurent (1989b) provides an additional compilation of data on Mediterranean marine turties.

Individual country accounts comprise the main body of the report. Fach account includes information arranged under the following headings (sections are omitted if no appropriate data are available): General remarks, Nesting sites and numbers, Population trends, Turtles at sea, Threats, Conservation measures, Miscellaneous. Where possible, the section on nesting sites and numbers is duplicated to allow separate treatment of Loggerhead Caretta caretta and Green Turtle Chelonia mydas populations. A few longer sections are divided under unnumbered sub-headings which are not necessarily consistent between country accounts.

Although some effort has been made to present available numerical data concerning tracks and nests, and the estimates of female numbers that can be: derived frum them, the limitalions of these data should be borne in mind. In particular, data from one site are unlikely to be strictly comparable with data from another, collected by different [ield workers. Not even imprecise data are available for some sectors of the Mediterranean coast; many of the conclusions arrived at herein will need modification in the light of future study. 


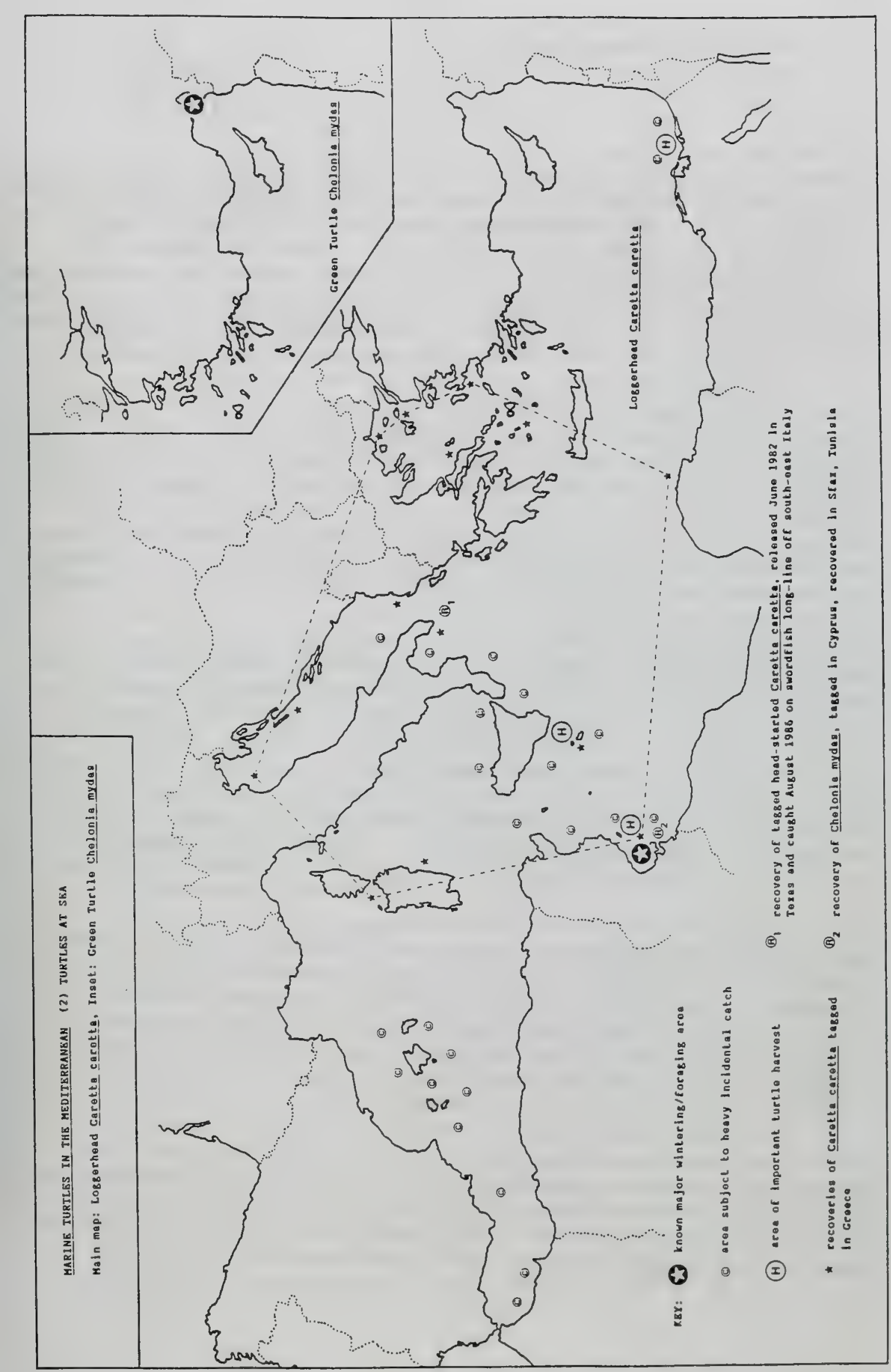




\subsection{SUMMARY}

2.1.1. Two marine turtle species nest regularly in the Mediterranean: the Loggerhead Caretta caretta and Green Turtle chelonia mydas, the former is the most widespread and most common. Three further species are present but do not nest: the Leatherback Dermochelys coriacea has been recorded with some regularity, and has been suspected to nest on occasion; the Hawksbill Eretmochelys imbricata and Kemp's Ridley Lepidochelys kempi are extremely rare in the Mediterranean and appear to be accidental immigrants to the basin. The coasts of Libya, Egypt and Syria have not been surveyed for turtle nesting, so available information on nesting sites is incomplete; it is possible that significant nest sites remain to be discovered, particularly in North Africa.

2.1.2. Loggerhead Caretta caretta nesting beaches exist in Greece (most notably on Zakynthos, also in the Peloponnesus and elsewhere). Turkey (southern coast), Cyprus and Libya. Nesting occurs in Tunisia, where numbers appear very low, and probably in Egypt. An occasional isolated clutch is laid on Lampedusa (Italy), Sicily, Israel and perhaps Sardinia; nesting appears formerly to have been less sparse at all these sites (most certainly in Israel). Nesting formerly occurred on Corsica and Malta, where none is known at present. Based on data from known nesting sites, there may be on average some 2000 female Caretta nesting annually in the Mediterranean; the majority shared between Greece and Turkey.

\subsubsection{The Caretta population nesting around Laganas Bay on Zakynthos} (Greece) is by far the largest single nesting colony known in the Mediterranean, and has held perhaps 300-700 nesting females in recent seasons, but this area is now severely disturbed by tourist development. Beaches around the west of the Bay are now unsuitable foc nesting because of noise, lights, vehicles, and general intense human activity; nesting is concentrated on the most isolated beach, where density is high. Recent planning and land-use decisions, which in principle could protect the population, have not been effectively implemented. Although recent nesting data show no clear evidence for a sustained decline in numbers, the population is acutely threatened by modifications to the nesting beaches and adjacent waters, and future decline seems inevitable without urgent remedial measures.

2.1.4. Loggerhead nesting is widespread along the southern coast of Turkey. Virtually all sites in Turkey are threatened by present or planned tourist developments; the latter are currently being reassessed with regard to turtle conservation needs. Dalyan-Iztuzu, one of about ten sites of similar importance, probably had around 100 females nesting in 1987 . Plans to greatly increase tourism at Dalyan were modified in 1988. The Turkish Government designated Dalyan-Iztuzu and Fethiye as Specially Protected Areas in 1988, and similarly designated important Caretta beaches at Patara and the Göksu Delta in 1990 (plus Ekinchik, a minor nest site).

2.1.5. The Caretta population nesting on Cyprus is relatively small and diffuse; low numbers nest at several sites. Most beaches in southern cyprus are now heavily developed; important beaches remain in the Lara area and around Polis. Recent legislation further strengthens turtle conservation at Lara, and the area is within the recently declared Akamas National Park. A hatchery operation exists at Lara, where a large number of clutches are transplanted in an effort to reduce natural mortality due to predation and 
inundation. Many sites along the north coast are little disturbed, but the tourist industry is capidly expanding and development is already planned for some notable sites; three recently designated protected areas include turtle nesting beaches.

2.1.6. The Green Turtle Chelonia mydas nests, so far as is known, only in extreme south-east Turkey (mainly at Kazanli and Akyatan on the Cukurova Delta), and in cyprus (an occasional nest is recurded in Israel). Nesting might occur in Egypt. An intense commercial fishery for the species existed in the eastern Mediterranean, notably off the northern coast of present-day Israel (between World War $I$ and II) and in south-east Turkey (afler World War II). Many thousands of Green Turt.les were harvested by both these fisheries; the extirpation of the Israel population and the near extirpation of the Turkish population, are attributed largely to over-exploitation, exacerbated more recently by development. Nesting numbers in Turkey are not ksiuwn in detail; recent preliminary data suggest in the region of 300-350 females nested in 1988, considerably fewer than the 1000 or more suggested by 1979-1982 data. This C. mydas population, by far the largest known in the Mediterranean, nust be regarded as acutely threatened. Nesting numbers in Cyprus are incompletely known, but recent data suggest around 25 females may nest annually in the Lara area, and similar numbers on northern beaches.

\subsubsection{Without exception, every country nesting population for which}

information is available is either significantly threatened, most evidently by international tourism and coastal development, or is known to have declined during the present century. Almost all known large nesting populations, particularly at Laganas Bay in southern Zakynthos, Greece, and along the southern coast of Turkey, are threatened to a greater or lesser extent by tourist development. A very few local populations, for example, the Chelonia nesting at Lara in west cyprus and near Dipkarpaz in the north-east, or the Caretta nesting around Kiparissia Bay in the Peloponnesus, appear to be relatively undisturbed on their nesting beach.

2.1.8. No nesting population of marine turtles in the Mediterranean is large by world standards. Overall, the conservation status of marine turtle populations nesting in the Mediterranean region ranges from poor, in the case of Caretta, to very poor, in the case of Chelonia mydas, and their long-term survival prospects are not favourable without the rapid inplementation of rigorous protection and management measures.

\subsubsection{There may be some 50000 incidental catch events annually; a} significant number of turtles, appear to be caught more than once. The mortality so caused is uncertain, but may be in excess of 10000 . This is equivalent to many times the entire estimated annual nesting contingent in the Mediterranean. Few data are yet available fue the eastern Mediterranean, but by far the greater part of the known incidental catch occurs in the swordfish long-line fishery around the Balearic Islands, and the catch may be comparable in south Italian waters. Depending on the frequency with which Atlantic turtles enter the Mediterranean, a significant proportion of the incidental catch pressure may be borne by turtles not of Mediterranean origin.

2.1.10. Pollution is also affecting Medilerranean turtle populations, but this phenomenon is as yet poorly investigated. Certain beaches, especially in Cyprus and in south-east Turkey, are heavily conlaminated by seaborne plastic waste and tar. A significant number of Loggerheads around Malta and in nearby waters have been observed with tar applied to the head and mouth cavity, and in the gut. Large numbers of Caretta washed up dead on beaches in south Italy 
are reporledly affected by pollution. The occurrence and effect on turtles of other pollutants, including heavy metals and pesticide residues, is little known. Turtles in south east Turkey arc exposed to heavy metal pollution and pesticide runoff from intensive cultivation in the plains south of Adana.

2.1.11. Until much reduced in 1989-1990, exploitation of marine turtles for food occurred on a large scale in Tunisia, where an estimated 5000 caretta were harvested annually after incidental catch by trawlers. Exploitation is also significant in Egypt, Morocco, and around Malta, Sicily and Sardinia. All turtles are taken at sea, not from nesting beaches. Present pxploitation in the central Mediterranean constilutes a substanlial threat to turtle populations in the region. Reduction and control of turtle fisheries are essential; on present information, turtle utilisation is of particular socio-economic imporlance only in Tunisia, where turtle meat is available more cheaply than fish, and Egypt.

2.1.12. Marine turtles from At antic nesting populations are certainly able to penetrate the straits of Gibraltar (and presumably the suez Canal) and enter the Meditercancan; a significant proportion of the Loggerheads found at sea around the Balearic Islands and in central Mediterranean waters are suspected to be inumigrants from the $\Lambda$ tlantic. One young Loggerhead released as a yearling in Texas was recaptured in Italian waters four years later. Whether a significant number of turtles move in the other direction, out of the Mediterranean, is entirely unknown; the current regime in the straits and the overall shape of the basin may make this difficult.

2.1.13. Information on the distribution of turtles outside the nesting season is incomplete; most observations are made by fishermen, mostly while fishing for finfish or crustaceans, and records to some extent reflect the distribution of observers. The Gulf of Gabès, in southern Tunisia, is evidently a major turtle feeding and wintering area. Most recaptures of Caretta tagged in Greece have occurred here, mostly during the winter months. The Gulf of Mersin and the Gulf of Iskenderun off south-east Turkey are major feeding and wintering grounds for Chelonia; inmatures, sub-aduits and adults are consistently found throughout the year. There is some evidence for a regular Caretta over-wintering or hibernation area in the central-north Adriatic.

\subsection{RECOMMENDATIONS}

2.2.1. The major nest beaches together with adjacent waters used by breeding turtles must receive adequate protection as a matter of great urgency.

If these sites are not adequately protected, the rapid expansion of international tourism and other coastal development are likely to depress nesting and hatchling production below tolerable limits.

The elements essential to achieve protection of most of the major nesting beaches are outlined in the Reconmendations made to the Governments of Greece and Turkey by the standing Conmittee of the Cunvention on the Conservation of European Wildife and Natural Habitats. The general Recommendation concerning protection of turtles and turtle habitat includes recommendations for beach protection, control of development, research work, coordination and education. These Recomendations should be implemented as widely and rapidly as possible, and progress in this regard should be monitored and reported. 
Nesting bcaches most requiring protection are:

1. Caretta nesting beaches around Laganas Bay, Zakynthos.

2. Major Caretta nesting beaches in southern Turkey including Dalyan and Patara, among others (the relative importance of the 10 major sites identified by Baran and Kasparek, 1989a, is not known in detail).

3. Major Chelonia nesting beaches in south-east Turkey, notably Kazanli and Akyatan beaches on the coast of the Cukurova Delta south of Adana.

4. Chelonia nesting beaches on Cyprus, including the Lara area, and beaches on the Karpas Peninsula, particularly those north-west of Dipkarpaz.

Because of the evidence for massive population decline and the vestigial numbers now nesting, top priority should be given to chelonia nest beaches in south-east Turkey and Cyprus.

2.2.2. Actions are also reguired to protect turtles outside the nesting phase of their life cycle, notably on foraging grounds, when they are affected by incidental catch, intentional fishing, and pollution.

With the apparent exception of Egypt, Malta, and south ltaly, there is relatively lillie harvesting of marine turtles in the Mediterranean. Most turtle catch is incidental to other fishing activities, although in Tunisia turtles caught incidentally by trawlers are harvested. The extent to which pressures affecting turtles in the Mediterranean are borne only by turtles from Mediterranean nesting beaches, or by immigrants from outside the Mediterranean, is unknown. Priority actions include the following:

1. Further investigate technical and educational means of reducing incidental catch of turtles, and reducing the mortality so caused.

2. Establish more accurately what proportion of turtles caught accidentally are killed as a result.

3. Investigate to what extent the pressure of incidental catch is borne by turtles from nesting populations outside the Mediterranean.

4. More generally, investigate the extent and pattern of turtle mosement between the Mediterranean and the Atlantic.

5. Wherever possible, eliminate intentional harvest of turtles. Means nust be found to reduce reliance on turtle meat among coastal communities, notably in Tunisia, where it is currently an important food source.

6. Further investigate the location of preferced foraging grounds, and over-wintering areas, both to improve scientific understanding and to allow the possibility of reducing threats to turtles outside the nesting season.

7. Investigate the extent to which pollution, including hydrocacbon residues and the reported agrochemical and heavy metal pollution in waters off south Italy and south-east Turkey, is affecting turtle populations, and examine the feasibility of reducing such pollution. 
2.2.3. Information on turtle populations is sparse or lacking for Libya, Egypt and syria. These areas should be surveyed to allow more complete assessment of the overall condition of marine turtle populations in the Mediterranean.

2.2.4. Every effort should be made to preserve natural conditions at nest beaches. Caution should be exercised over invasive and manipulative operations, such as are involved in hatchery operations or in certain kinds of research into nesting biology. Hatchery operations are only to be encouraged where natural lusses can demonstrably be minimised, and not as a remedy for loss or disturbance of nesting beaches where this can be avoided.

2.2.5. Current research and conservation efforts direcled at Mediterranean marine turtles are poorly coordinated, leading to inefficiency in the use of time and financial resources. One overall centre or organisation should oversee such work, rather than several apparently competing organisations as at present. The conservation status of Mediterranean marine turtles is an international problem and will require international solutions and finances. More effective coordination of existing and future research and conservation efforts is required, together with more efficient collection and dissemination of related information. 


\subsection{General remarks}

Two marine turtle species aro known to nest regularly in the Mediterranean: the Loggerhead Caretta caretta, and Green Turtle Chelonia mydas.

Both species are circumglobal in distribution; the Green Turtle is quite strictly tropical and sub-tropical, but the Loggerhead occurs most frequently at higher latitudes, in sub-tropical and temperate regions. This apparent difference in temperature preference is to some extent reflected in the distribution of the two species within the Mediterranean. Along the Turkish coast, for example (Geldiay et al., 1982), the eastward limit of Caretta nesting corresponds closely to the $24-26^{\circ} \mathrm{C}$ sumer isotherm, whereas Chelonia is enlirely restricted to more easterly regions with a summer mean of $28^{\circ} \mathrm{C}$ or more; all known Chelonia nesting in the Mediterranean is in the extreme east. Conversely, Caretta is the only nesting species in tie central Mediterranean, and nesting becomes sparse or non-existent toward the west, where mean temperatures may be too low. Loggerheads leave the north-west Mediterranean, Corsican waters, for example, as temperatures fall in autumn and winter. It is not clear, however, to what extent the present nesting distribution is a result of human modifications to turtle habitats. Further details of nesting are provided in the country accounts below.

\subsection{ALBANIA}

Little recent information is available. Argano and cocco (1988) report that a Caretta tagged of south Italy was recaptured off Albania, as was a female tagged whilo nesting in Grecce (Margaritoulis, 1988a). Turtles are likely to occur regularly in Albanian waters. Frommhold (1962) recorded seeing a specimen of Caretta and of Dermochelys, both caught in Albanian waters, in the Zoological Institute of the University of Tirana. Nesting of any significance seems most unlikely. No records of past nesting have been located.

\subsection{ALGERIA}

\subsubsection{Nesting sites and numbers}

Although not all beaches have yet been surveyed during the probable nesting season, there appears to be no significant marine turtle nesting in Algeria; there is some evidence that very occasional isolated nesting emergences are made. There is no evidence for the existence of past nesting colonies. Although suitable sandy beaches are present, relatively low water temperatures linked with the current regime of the western Meditecianean probably inhibits turtle nesting, as may also be the case in spain and Morocco.

After preliminary fieldwork in 1978, Argano reported that the Algerian coast is of no particular interest as regards turtle nesting, despite presence of extensive beaches (Argano, 1979). According to the Direction des Parcs et de la Protection de la Faune (in litt., 10 September 1986), neither Chelonia mydas nor Eretmochelys have been reported from Algeria.

Laurent (1989a) surveyed a sample of beaches, interviewed fishermen and others, and examined relevant literature dating back to the middle of the nineteenth century. He observed no evidence of nesting activity during June 
and July. Among many persons interviewed, only three recalled having scen presumed turtle tracks in the past (two had seen single tracks, one had seen a group of four at Andalouses in western Algeria); no documentary evidence of these reports was available. Laurent found no first-hand reports of nesting in the historic or recent literature, and no documented reporls; for example, a report by Doumergue (1899) appears to refer entirely to sub-adult Caretta (maximum length $70 \mathrm{~cm}$ ) found at sea, and a work by Fournet (1853) explicitly refers to the absence of turtle nesting in Algeria.

\subsubsection{Turtles at sea}

Historical sources cited by Laurent (1989a) indicate that Caretta was abundant in the mid-nineteenth and early twentieth centuries. Substantial numbers of Caretta are caught accidentally by fishermen at present (Laurent, 1989a), which implies that large numbers still occur off the coast of Algeria. According to Chalabi (in 1itt., 19 september 1988) Dermochelys is sometimes caught accidentally by fishermen.

A group of several hundred Caretta, estimated to weigh between 20 and $60 \mathrm{~kg}$ each, was seen by crew of the car ferry "Tassili" some $100 \mathrm{~km}$ from the oran coast of Algeria, while on passage from Alicante (Spain) (Lanteri, 1982). This observation was made at around 16.00 hours on 17 February 1980; the turtles were facing east, about $10 \mathrm{~m}$ apart and the encounter lasted for nore than 15 minutes (Lanteri, 1982) (see sections on Egypt and Gibraltar, below, for other examples of mass movements).

\subsubsection{Threats}

Loggerheads in the Oran region of western Algeria are not infrequently captured accidentaliy in nets or on long-lines; not being used for food, the turtles are typically released by fishermen (Lanteri, 1982). On the other hand, Laurent (1989a) estimated, after interviewing many fishermen at a sample of ports, that some 500 caretta are caught (and re-caught) annually in Algeria, mostly on swordfish long-lines. All catches appear to be accidental, perhaps $10 \%-30 \%$ are not released; although there is virtually no conmerce in turtle products, the fishermen responsible may keep carapaces for decoration and sometimes use turtles for food (Laurent, 1989a). Literature sources cited by Laurent (1989a) confirm that turtles were much in demand during the nineteonth century and, locally at least, until the 1940s. Turtles were at that time fished for intentionally rather than caught incidental to other fishing activities, as at present, and were sought for medicinal and food purposes, and for the extraction of oil (Laurent, 1989a).

\subsubsection{Conservation measures}

There is no protective legislation in force.

\subsection{CYPRUS}

\subsubsection{Nesting sites and numbers: Loggerhead Caretta caretta}

The Loggerhead nests on beaches around the Akamas Peninsula in western Cyprus, notably in the Lara area on the southern shores of the peninsula, and around Polis, east of the Akamas. The species also nests sporadically and in very small numbers on several of the least-dislurbed beaches around southern Cyprus (Demetropoulos and Hadjichristophorou, 1986, 1987, pers. comm. 9 July 1988). Beaches in the Lara region: include, in south to north order. Toxeftra 
(c. $1 \mathrm{~km})$, Ayile Phanentes $(1.5 \mathrm{~km}$ ), and Lara south, central and north beaches $(3 \mathrm{~km}$ in total). On the north side of Akamas, there are a number of stretches of sand beach both west and east of polis, perhaps $10 \mathrm{~km}$ in total length.

Surveys in the Polis area suggest that significant Caretta nesting occurs, but quantitative data are not yet available (Demetropoulos and Hadjichristophorou, pers. conm. 9 July 1988).

The Loggerhead nests widely around the northern shores of Cyprus, at some 36 separate beaches, but no single site supports dense nesting. During a survey between 18 June and 14 July 1988, a total of 122 fresh Caretta nests was recorded (Groombridge and Whitmore, 1989). The highest mean nesting rate among sites investigated was 0.86 new nests/night, on a half-kilometre beach on the Karpas Peninsula. The only beaches in north Cyprus not investigated are around Morphou Bay in the west; Ramsay (1970) and Demetropoulos (pers. conm., 1988) confirm that some turtle nesting occurred here in the past, and local residents indicate that turtles still nest. The species and numbers involved are not yet known (although Ramsay stated that creen Turtles nested, and that eggs were sometimes collected).

The Caretta population nesting in southern Cyprus has been estimated to compeise around 300 turtles (Hadjichristophorou, pers. comm. 1986), although full data have not yet been published. This estimate is intended to include mature males, and is based on the possibility that females typically nest in alternate years (Demetropoulos and Hadjichristophorou, pers. comm. 9 July 1988). Given these conditions, an estimated 75 Caretta may nest in southern Cyprus each season. An alternative estimate is that 50 females nest at Lara, with another 100 using beaches in the Polis area and inside British base areas (Hadjichristophorou, pers. comm. 2 October 1989). Preliminary data from northern coasts of Cyprus (Groombridge and Whitmore, 1989) suggest that a similar number may nest there. A minimum of 150 females probably nest in Cyprus each season.

\subsubsection{Nesting sites and numbers: Green Turtle Chelonia mydas}

A small number of $\underline{C}$. mydas nest in the west, chiefly around the Akamas Peninsula, notably in the Lara area. Beaches in the Lara region include, in south to north order. Toxeftra $(c .1 \mathrm{~km})$. Ayile Phanentes $(1.5 \mathrm{~km})$, and Lara south, central and north beaches ( $3 \mathrm{~km}$ in total). The Chelonia population is estimated to comprise around 100 turtles (Demetropoulos and

Hadjichristophorou, 1987). This estimate is intended to include mature males, and is based on the possibility that females typically nest in alternate years (Demetropoulos and Hadjichristophorou, pers. comm. 9 July 1988). On this basis, some 25 female Chelonia may use the Akamas beaches each season. During a ten day period in early July 1988, in what was considered locally to be a good year for Green Turtle nesting, the mean nesting rate was about one nest per night in the entire Lara area (Demetropoulos, pers. comm. 10 July); this is equivalent to about 0.2 nests $/ \mathrm{km} / \mathrm{night}$. Sixteen $\mathrm{C}$. nydas were tagged while nesting during 1989, the largest number tagged in any season, bringing the total tagged in Cyprus to 46 females (Hadjichristophorou, pers. comm. 2 October 1989). No regular C. mydas nesting is known to occur elsewhere in southern Cyprus (Demetropoulos, pers, comm. 10 July).

A total of 96 fresh Chelonia nests were recorded on 28 beaches along north coasts of Cyprus during a preliminary survey between 18 June and 14 July (Groombridge and Whitmore, 1989). Most nests were on beaches toward the $t$ ip of the Karpas Peninsula, either within or just outside the boundary of the proposed Zafer Burnu National Terrestrial and Marine Park (it is recommended that the boundary be extended to include all sites in the area). The most 
important site consists of a bay about $3.75 \mathrm{~km}$ north-west of the village of Dipkarpaz, with a beach some $1.6 \mathrm{~km}$ in length, partially divided by small rock headlands. Nesting rate at this site was just over one nest/ $\mathrm{km} / \mathrm{night}$. If each female laid three clutches, a minimum of 32 females could have produced the observed total of 96 nests, however, other females will have nested before and after the survey period, and an estimate of 50 females is probably close to the seasonal total in 1988. The only beaches in north cyprus not investigated are around Morphou Bay in the west; Ramsay (1970) and Demetropoulos (pers. comm., 1988) confirm that some turtle nesting occurred here in the past, and local residents indicate that turtles still nest. The species and numbers involved are not yet known, although Ramsay (1970) stated that Green Turtles nested, and that eggs wore sometimes collected.

\subsubsection{Population trends}

Little firm evidence is available, although Demetropoulos and Hadjichristophorou (1987) state that both Caretta and Chelonia were more abundant in the past; this is based on reports from fishermen, and on the name of one locality (Khelones) in northern Cyprus, which suggests that it was notable for good numbers of turtles. Other beaches near Larnaka and other tourist sites almost certainly once held more nesting turtles than the negligible number now present. Gruvel (1931) noted that Cyprus supplied turtles, apparently mainly Caretta, to the turtle soup trade based in London; this is likely to have had an impact on nesting populations. There are no reliable historical data on past numbers, and thus on the magnitude of the apparent decline.

\subsubsection{Threats}

Tourism and agriculture are the main sources of income on Cyprus, and most beaches in the southern part of the island are already adversely affected by tourist development and are now totally unsuitable for turtle nesting (Hadjichristophorou, pers. comm., 2 september 1987); the remaining relatively undisturbed beaches, all in the Akamas area and around Polis, are threatened by development plans.

Beaches in north Cyprus are mostly relatively undisturbed at present, and some, primarily along the Karpas Peninsula, are virtually pristine (apart from presence of seaborne debris). Tourist development, however, is spreading westward and eastward from the main centre of Kyrenia midway along the north coast, and several parts of famagusta Bay are used as beach resorts. plans exist for tourist development at some important turtle nesting beaches, and disturbance appears to be increasing in parallel with increasing tourism.

Most beaches appear to be affected by pollution, in the form of tar balls and plastic litter, probably seaborne. Although nesting turtles must sometimes crawl through accumulations of such debris, the effect on nesting success is unknown (the visual amenity value of such beaches is of course diminished). Beaches in the Lara area are manually cleaned at intervals, and they tend to remain clear of litter for quite long periods (Demetropoulos, pers. conm.).

A significant number of turtles are caught off northern coasts, apparently by accident, as a result of fishing activities. Most or all are caught in set nets near to shore, often near nesting beaches, and many are drowned.

Estimates of the number so caught range from 10 to 50 animals per year; if a high proportion are mature animals, incidental catch will be having a severe adverse effect on the turtle population, which is not large. Demetropoulos and Hadjichristophorou (1987) reported that turtles are occasionaliy killed on 
the beach for their shell, and some turtles are drowned or killed when caught in fishermen's nets; although turtle populations have reportedly suffered as a result, no data are available on the numbers lost.

\subsubsection{Conservation measures}

\section{Protected areas}

The Lara beaches on the south coast of the Akamas Peninsula, which hold most known turtle nesting in southern cyprus, are currently leased by the Department of Fisheries and are managed as a nature reserve with the intention of minimising human disturbance during the nesting and hatching periods. Important amendments to the Fisheries Laws were issued in 1989 (Hadjichristophorou, pers. comm. 2 October 1989). These prohibit: (1) any vessel from entering waters off the Lara beaches below 20 metres in depth, (2) fishing without permit by any method other than with rod and Iine, (3) entering the beach area in the period between one hour before sunset and suncise, (4) driving any vehicle on the beach, (5) using tents, beach umbrellas, sunbeds, etc., unless in accordance with the Foreshore Protection Law. No other turtle nesting site in the Mediterranean is subject to such comprehensive conservation regulations. The Akamas Peninsula region, a hitherto remote and little-disturbed area (which includes an important. assemblage of other fauna and flora), now appears secure after its designation as a National Park; planning measures, including zonation, were under discussion in late 1989.

The proposed Zafer Burnu National Terrestrial and Marine Park, near the tip of the Karpas Peninsula in north-east Cyprus, includes significant turtle nesting beaches, but the boundary should be extended to include the important Chelonia nest beaches north-west of Dipkarpaz. Three important turtle beaches, at Dik Burun, Kirpasha and east of Kyrenia, were among six protected areas in north Cyprus declared by late 1989 (Koyuncuoglu, F., in Iitt., 13 December 1989).

\section{Hatchery}

The Department of Fisheries has operated a hatchery scheme in southern cyprus since 1978 , the first in the Mediterranean; clutches are collected and re-buried in beach hatcheries. A hatching rate of $75 \%$ is recorded at present, which compare:s favourably with $80-90 \%$ observed in untransplanted and non-predated nests (Demeteopoulos and Hadjichristophorou, 1987). A number of hatchlings have been head-started, mainly in floating tanks in paphos harbour; about 100 turtles are held at present. Reportedly some released yearlings and two-year old turtles have been seen in the Paphos region (Demetropoulos and Hadjichristophorou, 1987). About $100 \mathrm{C}$. mydas hatchlings were notched on the carapace margin before release in 1979. Two females nesting in 1989 reportedly had marks that may have represented notch scars, and it has been speculated (Hadjichristophorou, pers. conm., 2 October 1989) that they might have been members of the 1979 release (this would imply an extrenely rapid growth rate).

The curcent aim of the transplantation scheme, which has resulted in release of 3500-4000 hatchlings annually in recent years, is to reduce loss of clutches due to predation and to inundation. One survey indicated that more than $70 \%$ or nests were dug up by foxes; crows and ghost crabs are also reported to take hatchlings (Demetropoulos and Hadjichristophorou, 1987). A significant proportion of nests is laid within range of high tides. Nevertheless, the policy favoured by most turtle conservationists (Pritchard et al.. 1983) is to reduce all manipulative techniques to a minimum. 
Marine turtles and eggs are protected by law in Cyprus, by regulations made under section 135 of the Fisheries Law. The Lara beaches were recently protected under 1989 amendments to this law.

Table 1. Summary of selected data from Caretta and Chelonia nesting sites in Cyprus. Sources: Denetropoulos and Hadjichristophorou (pers. comm.); Groombridge and whitmore (1989).

\begin{tabular}{|c|c|c|c|c|}
\hline Nesting area & $\begin{array}{l}\text { Beach } \\
\text { length } \\
\text { (km) }\end{array}$ & $\begin{array}{l}\text { Nests } \\
/ \mathrm{km} / \mathrm{night}\end{array}$ & $\begin{array}{l}\text { Total } \\
\text { nests/ } \\
\text { season }\end{array}$ & $\begin{array}{l}\text { Females } \\
\text { nesting/ } \\
\text { season }\end{array}$ \\
\hline
\end{tabular}

Cyprus: south coast

Lara region
Caretta

Chelonia

$>75$ ?

25

Cyprus: north coast $30 \mathrm{~km}^{2}$

Caretta

Chelonia

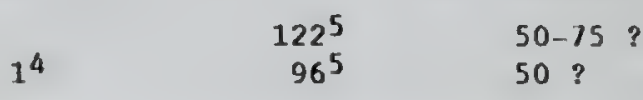

Notes to Table 1: 1 the beach length figure refers to the Lara area only (there is virtualiy no nesting elsewhere in the south, with the exception of the Polis area, not yet surveyed): 2 this is close to the total beach length suitable for turtle nesting in the north (with the exception of Morphou Bay, not yet surveyed; 3 for the Lara area $(5.5 \mathrm{~km}) ; 4$ for the bay north-west of Dipkarpaz $(1.6 \mathrm{~km}): 5$ incomplete estimates based on data collected 18 June-14 July 1988 only (Groombridge and Whitmore, 1989).

\subsection{EGYPT}

\subsubsection{General remarks}

Little recent information is available. Both Chelonia mydas and Caretta caretta occur in Egyptian Mediterranean waters (Flower, 1933), and appear in coastal markets. Caretta is the most common species (Flower, 1933). Marine turtles have been observed in Lake Manzala (Flower, 1933) and Lake Bardawil (N. Varty, pers. comm. 1989), west and east of Port Said, respectively. Loveridge and Williams (1957) cited records of Chelonia from the Port Said area, and Caretta from Alexandria, Brullos, Damietta and Port Said (these localities appear to be taken from Flower, 1933).

\subsubsection{Nesting sites and numbers}

Flower (1933) recorded that marine turtles nested on the Sinai coast; Ei Arish was the only locality specified. Although flower had no evidence as to the species involved, one of his informants described a nesting turtle he had seen as "very large", suggesting that it might have been chelonia rather than Caretta. According to a map published by sella (1982) scattered sea turtle nesting occurs on the sinai coast between Port Said and the Gaza area (no evidence was discussed, and this map might have been based on Flower's information). More recently, marine turtles have been confirmed to nest on 
the sandbar separating Lake Bardawil from the sea, seemingly in significant numbers (observations of Wahid Salama, Egyptian Environmental Affairs Agency); the species involved is uncertain, but Chelonia have been observed in the Lake.

\subsubsection{Turtles at sea}

In the early twentieth century Caretta was the most common turtle in Egyptian Mediterranean waters (F'lower, 1933).

On september $17 t h, 1947$, numerous turtles were encountered by a westbound steamer some 350 miles west of Port Said (Egypt); the turtles were seen over a distance of around 60 miles and all were swimming east towards port said, separated from one another by about 200 yards (Deraniyagala, 1951). The turtles were about $2^{\prime} 6^{\prime \prime}$ long and greyish green in colour, and were presumed to be either Chelonia mydas or Lepidochelys; because the latter has been recorded exceedingly rarely in the Mediterranean, and because of their colour, the turtles seen were most likely to have been Chelonia. isee sections on Algeria and Gibraltar for other examples of mass movement by sea turties).

\subsubsection{Threats}

Coptic communities on the Mediterranean reportedly (Goodman, S., pers. comm., 10 June 1986) utilise many turtles (species uncertain, presumably Caretta or Chelonia). The turtles are kept alive in the market until required, when the throat is cut (turtle blood is drunk in the belief that it enhances fertility). Flower (1933) recorded that Chelonia could often be bought alive in Port Said, but were always blinded owing to injuries received from fishermen; the same appears to have been true of Caretta. According to Flower, the Loggerhead was much appreciated as food in hotels and on passenger steamers, apparently both in Egypt and elsewhere in the Mediterranean. significant numbers are slill taken at present; one narket trader alone estimated he handles 20-40 large turtles annually ( $N$. Varty, pers. comm., 1989).

\subsection{FRANCE: CORSICA}

\subsubsection{General remarks}

Four species of marine turtle have been recorded in French Mediterraliean waters (Fretey, 1987). Only Caretta and Dermochelys appear to occur in significant numbers; there are only one or two records of Chelonia and one record of Eretmochelys (reportedly caught near Marseilles; source cited by Fretey, 1987).

Caretta is the only nesting species and nesting has been reported only from Corsica (Delaugerre, 1988; Fretey, 1987). Fretey (1987) also cited speculation by other authors that nesting by Dermochelys may be possible on the numerous sandy beaches around the Golfe du Lion, where most records of the species in French Mediterranean waters have been made.

\subsubsection{Nesting sites and numbers: Loggerhead Caretta caretta}

The Loggerhead has been reported to nest during the present century, although sites and numbers are unknown in detail. A 1970 letter from G. Testa (Musée Océanographique de Monaco) to $M$. Dumonl indicated that Caretta eggs had been collected on the fine sand beaches in eastern Corsica in 1923, 1928 and 1932. 
This information was published by Dumont (1973, 1974) and Bruno (1973), and is discussed by Delaugerre (1988). Localities included Moriani beach in the Cervione region, and Aleria, between l'Etang de Diane and I'Etang de Sale.

Thibault et al. (1984) cite the evidence of a resident of Ghisonaccia that nesting was not exceptional on the beach at Domaine de Pinia during the 1960s, but Delaugerre (1988) rejected this evidence after further interviews.

Delaugerre also reported information from a resident of solenzara, apparently confirmed by others interviewed, that eegs were sometimes collected from the dunes near Aléria and $I^{\prime}$ anse de Favone during 1935-1940.

Although documentary evidence is lacking. Delaugerre (1988) concluded that only a small number of Caretta nested on beaches in eastern Corsica, perhaps irregularly, at the turn of the century. These beaches are probably marginal habitat for Caretta nesting, and development and disturbance appear to have brought to an end whatever sparse nesting may have occurred in the past. No nesting has been observed in recent decades.

\subsubsection{Population trends}

According to Delaugerre (1988), available evidence suggests that turtle numbers have declined steeply over the past 20-30 years. However, there is no evidence that large numbers nested in the past, and in the absence of historical data the magnitude of the sugested decline in nesting numbers cannot be assessed. Caretta appears to have been common at sea in the Bonifacio area during the early 1960s, when they were traditionally eaten by fishermen on Saint Erasmus day (June 2nd) (Delaugerre, 1988). Fretey (pers. conm., January 1988) reporled information from fishermen that turtles are sefr less frequently than 20 years ago.

\subsubsection{Turtles at sea}

Loggerheads have been observed in Corsican waters during most months, with tlis exception of October, November, December and January. Records are at a peak during June, July and August, with a sudden fall in frequency around the end of August. Delaugerre (1988) suggests that Caretta leave the area in autumn in favour of warmer waters to the south and east. Records are almost all of individual animals, very occasionally of two to five, and exceptionally of several turtles. They are grouped in three main areas: the southern part of the east coast between Aleria and Bonifacio, the Cap Corse region, and the north-east including the scandola peninsula. These groupings may to some extent reflect the distribution of observers rather than turtles. However. fishermen on the east coast report that Caretta are seen most frequently in two quite well-defined areas (south-east of Cerbicale, and between Aléria aris Favone, in particular); these may be preferred foraging grounds for the Loggerhead (Delaugerre, 1988).

\subsubsection{Threats}

A significant, but uncertain, number of adult and sub-adult turtles (mostly 60-100 cm length) are caught around Corsica, mainly between mid July and eari; August when turtles come closer to shore; they are caught in nets and most ars dead when found (Fretey, pers. comm., January 1988). Of 48 records discusse by Delaugerre (1988), 28 refer to Caretta caught by nets, Lrawls or long-lines; one fisherman caught four Caretta during five wceks in his spiny lobster net. These nets, generally set on the sea bed between $40 \mathrm{~m}$ and $120 \ldots$ are an important cause of mortality among Loggerheads in Corsican waters 
(Delaugerre, 1988). Unlike fish nets, lobster nets may remain in place for several days, and virtually all trapped turtles are drowned (in contrast, most turtles caught by other means are recovered alive). Because of the good financial rewards, a significant part of the fleet in Corsica is now devoted to the specialised spiny lobster fishery (Delaugerre, 1988).

\subsubsection{Miscellaneous}

Delaugerre (1988) records a number of size estimates, mostly within the $70-80 \mathrm{~cm}$ total length class; this corcesponds approximately to a carapace length of $52-59 \mathrm{~cm}$. The average of three direct measurements of carapace length is $56.4 \mathrm{~cm}$ (whether straight or curved length is not specified). The $30-35 \mathrm{~kg}$ weight class was best represented (most weights estimated). Most Caretta in Corsican waters thus appear to be below the size range of turtles breeding in the central and eastern Meditercanean (range $55-74.6 \mathrm{~cm}$ straight carapace length at Dalyan, Geldiay et al., 1982; mean $80.4 \mathrm{~cm}$ curved carapace length at Zakynthos, Margaritoulis, 1982 ; mean $83.1 \mathrm{~cm}$ curved carapace length at Kiparissia Bay, Margaritoulis, 1988b). One female $76 \mathrm{~cm}$ in total length was found to contain a number of eggs.

Gut contents of two turtles included a crab in one specimen, and cephalopod remains, a pteroides, plastic bags and sweet wrappers in a second (Delaugerre, 1988).

\subsection{GREECE}

\subsubsection{General remarks}

The Loggerhead Caretta caretta is the only species known to nest in Greece No Chelonia nesting is known, although a few inmature specimens have occurred in Greek waters (Margaritoulis et al., 1986). A total of 11 Dermochelys was recorded betweon 1982 and 1984, suggesting that significant numbers may occur in Greek waters (Margaritoulis, 1986).

\subsubsection{Nesting sites and numbers: Caretta caratta}

Nesting by caretta has been reported from six areas, although information is not yet complete. Known nesting areas comprise: the southern part of Zakynthos and southern parts of Cephalonia (both in the Ionian island group off the west coast of (reece); the Peloponnesus, notably kiparissia Bay in the west, also at Lakonikos Bay in the south-east, and on other small beaches; the islands of Crete and Rhodes (Margaritoulis, pers. conm. September 1987; Marinos, 1981).

On present information, Zakynthos is by far the most important turtle nesting area in Grecce, and by far the largest single concentration of Caretta nesting in the Mediterranean; numbers are moderate in the Peloponnesus, low on Cephalonia, and apparently low and somewhat irregular at other sites.

\subsubsection{Zakynthos}

Zakynthos is one of very few turtle nest sites in the Mediterranean which lacks foxes Vulpes vuipes (Margaritoulis, 1987a); the large size of the nesting population may well be correlated with the absence of nest predation by foxes, very heavy at many other known sites (elsewhere in Greece, also Turkey and Cyprus). An estimated 57\% of clutches laid in 1984 at Kiparissia 
Bay (west Peloponnesus) were disturbed by foxes and dogs, but in 1987 whilst nearly half of the sample nests monitored were disturbed, very few were totally destroyed (Margariloulis, 1987a, 1987b).

Seven nesting beaches occur, distributed acound the Gulf of Lagana in the south-east of the island (sec Margaritoulis, 1982, 1987a, for further details). These comprise, in west to east order: a small beach on the north-east coast of Marathonissi island, East Laganas (2 km), Kalamaki $(250 \mathrm{~m})$, Vrodonero $(150 \mathrm{~m})$, Sekania $(350 \mathrm{~m})$, Daphni $(250 \mathrm{~m})$ and Gerakas $(500 \mathrm{~m})$. The total beach. length used by nesting turtles is around $3.7 \mathrm{~km}$ (Margaritoulis, 1987a).

It is thought that Lagana beach used to be the major site, but currently most nesting occurs on sekania now that tourist development has increased disturbance generally and rendered the western sector $(1.5 \mathrm{~km})$ of Lagana beach largely unsuitable for nesting (Margaritoulis, 1982). This suggested shift to

Table 2. Summary of selected data from Caretta nesting sites in Greece. Key to sources: $a=$ Sutherland (1984), b = Margaritoul is (1987a), $c=$ Margaritoulis (1987b), d = Sea Turtle Protection Society (report 2 October 1989), $e=$ Margaritoulis (1988b), $f$ = Margaritoulis (pers. comm.), $\mathrm{g}$ = Sutherland (undated).

$\begin{array}{lllll}\text { Nesting area } & \text { Beach } & \text { Emergences } & \text { Nests } & \text { Total Source } \\ & \text { length } & / \mathrm{km} / \text { season } & / \mathrm{km} / \mathrm{season} \text { nests/ } \\ & (\mathrm{km}) & & & \text { season }\end{array}$

\begin{tabular}{|c|c|c|c|c|}
\hline Zakynthos & & & & \\
\hline total mean $1983-89$ & 3.55 & 1337 & 417 & 1480 \\
\hline Sekania beach only & 0.35 & $\left(6268^{1}\right)$ & $\left(2022^{1}\right)$ & 708 \\
\hline
\end{tabular}

$\begin{array}{lccccc}\text { Kiparissia Bay (west Peloponnesus) } & & & \\ 1987^{2} & 42 & 30 & 12.3 & 517 & \text { e } \\ \text { main beach only } & 2.5 & & & 217\end{array}$

Lakonikos Gulf (south Peloponnesus)

$\begin{array}{llllll}1988 & 20 & 6.4 & 128 & \text { d, f }\end{array}$

\section{Cephalonia}

$\begin{array}{llllll}\text { Potamakia only } & 3 & 40 & 20 & 60 & 8\end{array}$

(mean 1985-87; very sparse nesting occurs in the south-west)

Crete

numbers uncertain, probably no dense nesting f

Rhodes

1988-89 mean $35 \quad 21$ d

Notes: 1 This figure is an extrapolated value, sekania beach is about one-third of a kilometre long. 2549 nests on $44 \mathrm{~km}$ in 1988 (d). 
Sekania is not evident from available data, which cover the seasons 1983-1989. During the 1977-1979 seasons, an average of 9.2 nests were made per night on Sekania (Margaritoulis, 1982), and 9.4 nests per night during the 1981 season (Margaritoulis, in litt., 1982). Sekania holds in excess of $50 \%$ of all nesting on Zakynthos, on about $10 \%$ of the total beach length at Laganas Bay. This beach also has the highest proportion of emergences leading to successful nesting, indicating that conditions are more favourable than on other beaches. Most beaches on Zakynthos have a relatively low proportion of successful nesting. For example, on Potamakia beach (Cephalonia) $45 \%-50 \%$ of emergences result in nesting, compared with an average of only $23 \%$ on Zakynthos, excluding Sekania, with $32 \%$.

A total of 2460 nests was recorded on Zakynthos in 1983 (Sutherland, 1984), representing a mean of around 665 nests per kilometre per season. Assuming, for comparative purposes, an average of 3 or 2.5 clutches per female per season, these data suggest an annual nesting contingent of 820 or 980 females, respectively. An alternative estimate for 1983 nesting (Margaritoulis, pers. conm., 1988) suggest a total of c. 2000 nests; this corresponds, with the above assumptions, to 666-800 females. Further estimates for the seasons 1984-1989 are given in Table 4 .

Table 3. Relative importance of nesting beaches around Laganas Bay, Zakynthos, as shown by select nesting data (means from 1984-1989 seasons). See Table 4 for sources.

Beach Length $(\mathrm{km})$

Nests as $\%$ Nests as $\%$ of emergences* of total nests on Zakynthos*

$\begin{array}{lllr}\text { Marathonissi } & 0.2 & 26 \% & 1 \% \\ \text { East Laganas } & 2.0 & 21 \% & 11 \% \\ \text { Kalamaki } & 0.25 & 24 \% & 8 \% \\ \text { Sekania } & 0.35 & 32 \% & 52 \% \\ \text { Daphni } & 0.25 & 18 \% & 12 \% \\ \text { Gerakas } & 0.5 & 29 \% & 6 \%\end{array}$

* Mean of 1984-1989 seasons

\subsubsection{Cephalonia}

Nesting has been recorded on three beaches (skala, Munda, Potamakia) near skala village in south-east Cephalonia, and, very sparsely, on two beaches near Lixouri in the south-west (Sutherland, undated; Whitmore, C., pers. comm.). Minor nesting appears to occur at several sites (Panou and Moschonas, 1990). Around $80 \%$ of all recorded nesting occurs on the $3-\mathrm{km}-1$ ong Potamakia beach (sutherland, undated). Selected data from the 1984-1989 seasons are presented in Table 5 . 
Table 4. Summary of selected data from Caretta nesting beaches around Laganas Bay, Zakynthos. See below for Key to Table, and Notes.

\begin{tabular}{|c|c|c|c|c|c|c|c|c|c|c|c|c|c|c|}
\hline & \multicolumn{2}{|c|}{$1983^{a}$} & \multicolumn{2}{|c|}{$1984^{c}$} & \multicolumn{2}{|c|}{$1985^{c}$} & \multicolumn{2}{|c|}{$1986^{d}$} & \multicolumn{2}{|c|}{$1987^{d}$} & \multicolumn{2}{|c|}{$1988^{\circ}$} & \multicolumn{2}{|c|}{$1989^{\circ}$} \\
\hline & $\mathrm{h}^{\mathrm{E}}$ & $\mathbf{N}$ & $\mathbf{E}$ & $N$ & E & $\mathbf{N}$ & E & N & $\mathbf{E}$ & $\mathbf{N}$ & E & $\mathbf{N}$ & $\mathrm{E}$ & $\mathbf{N}$ \\
\hline M & 355 & 151 & 284 & 67 & 318 & 77 & 321 & 88 & 360 & 105 & 376 & 89 & 382 & 123 \\
\hline L & $\begin{array}{r}514 \\
1047\end{array}$ & $\begin{array}{l}252 \\
205^{b}\end{array}$ & 482 & 124 & 542 & 137 & 961 & 190 & 778 & 117 & 534 & 127 & 779 & 168 \\
\hline K & 453 & 205 & 301 & 92 & 392 & 104 & 349 & 94 & 577 & 93 & 560 & 103 & 705 & 188 \\
\hline$s$ & $\begin{array}{l}2634 \\
2590\end{array}$ & $\begin{array}{l}1360 \\
1142^{b}\end{array}$ & 1761 & 595 & 1195 & 333 & 2506 & 1046 & 2341 & 611 & 2838 & 823 & 2083 & 840 \\
\hline D & 847 & 322 & 627 & 123 & 587 & 133 & 1274 & 294 & 1458 & 138 & $\cdots$ & $153 *$ & 1084 & 207 \\
\hline G & 344 & 147 & 219 & 60 & 178 & 73 & 497 & 110 & 262 & 46 & 354 & 113 & 309 & 118 \\
\hline & $\begin{array}{r}5411 \\
\mathrm{c} .\end{array}$ & $\frac{2460}{2000^{b}}$ & 3674 & 1061 & 3212 & 857 & 5908 & 1822 & 5776 & 1110 & -- & $1408^{*}$ & 5342 & 1644 \\
\hline
\end{tabular}

Indication of possible nesting female number/year (see Note 3)

$\begin{array}{llllll}820^{\mathrm{a}} & 354 & 286 & 607 & 370 & 470 \\ 667^{\mathrm{b}} & & & & \end{array}$

Key to Table 4. Column 1: M = Marathonissi $(0.2 \mathrm{~km}), \mathrm{L}=$ East Laganas $(2.0 \mathrm{~km}), K=$ Kalamaki $(0.25 \mathrm{~km}), S=$ Sekania $(0.35 \mathrm{~km}), D=$ Daphni $(0.25 \mathrm{~km})$, $\mathbf{G}=$ Gerakas $(0.5 \mathrm{~km})$. Total beach length: $3.55 \mathrm{~km}$. $\mathbf{E}=$ total emergences, $N$ = total nests. * Daphni beach was not regularly surveyed during 1988 ; the number of nests was estimated on the basis of occasional surveys (source e).

Key to sources: $\mathrm{a}=$ Sutherland (1984), $\mathrm{b}=$ Margaritoulis (pers. comm.), $c=$ Margaritoulis (1987a), d = Margaritoulis (in litt., data from 1988 report), e = Sea Turtle Protection Socicty report, October 1989.

Notes to Table 4. (1) Nesting data for the 1983 season were collected by two independent teams: Sutherland (1984) and a team supported by the Ministry of the Environment in Grecce. These data are indicated by superscripts a and b respectively. Although sutherland's report acknowledges limitations to his data (Laganas and Vrodonero beaches were examined only through binoculars from a boat, and sekania was not comprehensively covered), his figures cover all beaches and are thus included in the main body of the table. The Margaritoulis team made a more comprehensive survey, hut dealt with Laganas and Sekania only; their information for these two beaches is likely to be the more accurate of the two data sets available. (2) The very minor Vrodonero beach was not included in post-1983 surveys, and is excluded from the Table. (3) This is no more than an indication of total female nesting numbers, made on the assumption that each mature female at the beach in any one season will lay, on average, three clutches; these figures are included for comparative purposes only. 
Table 5. Selected nesting data from Potamakia beach, Cephalonia. Data from Sutherland (undated) and Anon. d (1990). Beaches were monitored for the complete nesting season of around 74 days (except in 1984, when observations were made over 50 days; extrapolated values assuming a 74 day season are given in parentheses).

Season

Emergences

Nests

Nests as \%

of emergonces

Number of individual

females seen

\begin{tabular}{lcccc}
1984 & $74(114)$ & $36(53)$ & $48 \%$ & 9 \\
1985 & 95 & 44 & $46 \%$ & 26 \\
1986 & 151 & 84 & $55 \%$ & 35 \\
1987 & 119 & 51 & $43 \%$ & 26 \\
1988 & 56 & 28 & $50 \%$ & 13 \\
1989 & 117 & 49 & $42 \%$ & $?$ \\
\hline
\end{tabular}

Much nesting on Potamakia beach occurs on the eastern half; most sea-borne debris on this beach also washes up here, suggesting that females may make use of local currents when approaching shore (Whitmore, C., pers. comm.). Potamakia is relatively undisturbed at present (Sutherland, undated). Hatching success was also highest on this beach. During the 1985 season, nesting reached a peak during the sccond wcek in June, and declined steadily thereafter until late August. The mean annual number of nests is about 50 , which corresponds to a density of 11 nests/ $\mathrm{km} / \mathrm{season}$, and a nesting rate of about 0.7 nests/night on Potamakia. One of 26 adult females tagged in 1985 bore a tag previously applied while nesting on Zakynthos (sutherland, undated; Whitmore, C., pers. comm.). Average number of clutches laid among nine females tagged while nesting and seen to re-nest was 2.8 .

The Cephalonia nesting contingent appears relatively small. The number of nests recorded, divided by the mean number of clutches per female, indicates that 18-19 females may have been present in 1985, for example; however, 26 mature females were tagged, suggesting that a majority of turtles present off the skala beaches may have nested only once or twice in the inmediate area.

\subsubsection{Peloponnesus}

Turtle tracks and nests have been recorded at several localities around the western and southern coasts of the peninsula (Margariloulis, pers. comm. 4 June 1988). Most observations have been made al Kiparissia Bay, western Peloponnesus, and Lakonikos Bay, southern Peloponnesus. Most nesting appears to occur on the extensive beach at Kiparissia Bay, where some 1272 emergences and 517 nests were observed during 1987 on a $42 \mathrm{~km}$ stretch between the Alfios River and the village of Kalo Nero (Margaritoulis, 1987b). The overall nesting density in 1987 was 12.3 nests/km, but nests were very unevenly distributed. Most nesting, up to a maximum of 86.8 nests/km on one sector. occurred in the south, between the mouths of the Neda and Arcadicos rivers. 
There were many fewer nests in the north, on the least dislurbed sectors that appeared superficially to be ideal for nesting; the reasons for this disparity are unknown (Margaritoulis, 1987b). A total of 549 nests were recorded on $44 \mathrm{~km}$ in 1988 (Sea Turtle Protection Society, report 2 October 1989). In contrast to Zakynthos, nest predation in Kiparissia Bay is very high; $48 \%$ of nests were disturbed in 1987, mainly by foxes. Tourist activity and other forms of development affecting turtles are not prominent at present. About $20 \mathrm{~km}$ of beach are monitored in Lakonikos Bay, where an estimaled 60-120 clutches may be laid per season (Margaritoulis, pers. comm.). In 1988, 128 nests were recorded on $20 \mathrm{~km}$ (Sea Turtle Protection Society, report 2 october 1989). There is relatively little development in the area, but much fishing activity, and a high rate of nest predation (Margariloulis, pers. comm.). Preliminary surveys have revealed turtle tracks and nests in strofilia-kotychi lagoon and on Romanos beach (Margaritoulis, pers. comm.).

\subsubsection{Crete}

Surveys have covered (although not systematically) most of the southern coastline, where only occasional tracks were seen, and some parts of the north coast. where in the 1985 season a total of five nests were found on one beach extending for some $20 \mathrm{~km}$ west from Rethimnon (Margaritoulis, pers. comm., 4 June 1988). Nesting on Crete appears to be very sparse and no nesting aggregations are known or suspected to exist. No information is available on past nesting density or population trends.

\subsubsection{Rhodes}

A few emergence tracks and nests have been recorded, mainly on beaches in the more remote southern half of the island; nesting numbers do not appear to be high. On about $35 \mathrm{~km}$ of beach in the south, 9 and 33 nests were recorded in 1988 and 1989 (Sea Turtle Protection Society, report 2 October 1989).

\subsubsection{Population trends}

All information derived from long-term monitoring relates to zakynthos and to Cephalonia.

\section{Zakynthos}

Long-term trends in nesting numbers are not known with certainty; no quantitative data are available on the size of past nesting contingents, but. the present nesting population has widely been regarded as greatly depleted (Margaritoulis, 1980). According to Margaritoulis (1980), older local inhabitants indicated that large herds of turtles could at times be found in the shallows waiting to come ashore and nest. Margaritoulis (pers. comm., December 1988) now feels less certain that a decline in numbers has occurred.

Numbers have fluctuated over the seasons in which surveys have taken place, and no clear trend is evident during this period. However, the total number of nests recorded in each of the six seasons in 1984-1989 has been lower than the total for 1983, the first for which useful data are available (whether estimates from sutherland or Margaritoulis are used), and the 1987 total was around 50\% of that in 1983. The number of emergences has been similar to that in 1983 during most seasons in the period 1984-1989, or somewhat higher, suggesting that the number of nesting females may have remained constant, but they have more frequently been deterred from nesting. No data are presently available allowing comparison of relative hatching success on the differenl 
beaches. Overall, the numerical evidence for a serious population decline following the start of intensive tourist development in the mid-1970s is questionable at best, and the evidence for a decline in the Zakynthos population during the $1980 \mathrm{~s}$ is not conclusive. However, there is no doubt that this population, the largest single sea turtle nesting colony known in the Meditercanean, is acutely threatened by tourist development; given the present severe disturbance to nesting and internesting habitat, the population is certain to decline in future without the most urgent remedial action.

\section{Cephalonia}

Available data, all relating to Potamakia beach (Sutherland, undated; Anon.d, 1990), show marked between-season variation in nest numbers, but no clear trend during the period 1984-1987.

\subsubsection{Threats}

\section{Zakynthos}

The Zakynthos Caretta population is threatened by various faclors associated with tourist development. These include: direct disturbance of turtles and nests by human activity; disturbance and disorientation of females and hatchlings by artificial lighting; bulding and tree planting on certain beaches; and the presence of speedboats in Laganas Bay. Tourism has expanded very greatly since the opening of an international airport on the island. The potential economic benefits of tourist development are sufficiently high that local landowners and the local community generally are not sympathetic to the management requirements of the Caretta nesting population. A 1980 Directive which declared the main beaches protected, provisional building restrictions in 1982, and a Presidential Decree of 1984, which imposed restrictions on building and land use, have all had little effect.

The western sector of Laganas Beach has since 1979 been fully occupied by housing and tourist development and is not now used by turtles; the eastern sector was formerly well-used for nesting but disturbance is now significant, particularly around the Kalamaki Beach Hotel at its eastern end. Some nesting still occurs, however. Kalamaki beach is still used for nesting but is heavily disturbed, particularly around the Cristal Beach Hotel. Sekania remains relatively little-disturbed. Nesting is so concentrated on sekania, supposediy as a result of increased disturbance elsewhere, that nesting turtles are said frequently to excavate and damage nests laid previously. On the other hand, Margaritoulis (pers. comm., 1988) reports that of the 1046 nests recorded in 1986, only 12 were destroyed in this manner. Daphni, second to sekania in importance, is now at risk from illegal buildings erected in 1986. Nesting continues at Gerakas and on Marathonissi island; both are disturbed by tourist activity, mostly evident during the day.

According to Venizelos (1987), by the mid-1980s most beaches were packed with sun umbrellas and deck chairs; the shore was lined with pedallos and other boats; sand had been removed from several areas for building purposes; beaches were being compacted by vehicles and general tourist activity; the bay itself was subject to dynamite fishing, trawling and speed boats. In addition, beach front development, including sea walls, cafés and tamarisk plantations (for shade), had proliferated and, despite many of these being declared illegal by the local administration, no action could be taken because of the strength of opposition from local landowners. The western beaches in particular were heavily disturbed after dark by sound and light pollution associated with 
discos and general tourist activity; this causes severe disturbance to nesting females and disorientation of emerging hatchlings. According to other sources (Margaritoulis, pers. comm., December 1988) the threat posed by many of the above has been somewhat exageerated: sand removal has been very limited, and restricted to dune areas behind the nesting beach; a fishery regulation prohibits trawling in closed bays (such as Laganas), and the little trawling that does occur takes place in winter (outside the nesting season).

The severity of the overall situation on the Zakynthos nest beaches was independently confirmed during an appraisal carried out by the Directorate of Environment and Local Authorities of the Council of Europe (Anon. a, 1987) and a consultant from the Societas Europaea Herpelologica (Anon. b, 1987). A follow-up appraisal, carried out in september 1989 (Anon. C, 1989), concluded that the situation had in many respects deteriorated since the first appraisal, and that liLtle real progress had been made with regard to implementation of Recommendation No. 9 of the Standing Conmittee made in 1987.

\section{Incidental Catch}

Panou and Moschonas (1990) report that 11 Caretta, averaging $45 \mathrm{~cm}$ in length (range 20-65 cm), were caught during 54 trips between March and August 1989 by one swordrish long-line vessel based in Kephalonia. All were released alive, mostly by cutting the line while hauling in. A second and third boat reported catching three and 15 turtles in the same season. Most turtle catches occur in July-August, presumably as turtles gather off nesting beaches. Turtles are occasionally eaten by Egyptian crew members. Japanese and Italian vessels using drift nets (for tuna and swordfish respectively) are also suspected of posing a threat to turtles in the area.

\subsubsection{Turtles at sea}

A total of 1525 Caretta were tagged in Greece during the 1982-1987 nesting seasons, the great majorily on Zakynthos and the remainder in Peloponnesus; up to March 1988, 34 tagged turtles (2.2\%) had been recaptured at distant sites (Margaritoulis, 1988a). Most recaptures were reported by fishermen, and about half of the recaptured turtles were said to have been released. Tag returns have come from a very wide zone, extending west to sardinia, east to western Turkey, south to Tunisia (Gulf of Gabès) and ribya, and north to the northern Aegean and the head of the Adriatic. Fourteen (41\%) of the 34 returns have come from the Gulf of Gabès, mostly during winter; other sites have reported between one and three returns (Margaritoulis, 1988a). It is not known to what extent this pattern reflects the differential distribution of tagged turtles or the magnitude of the turtle harvest in Tunisia. Taken at face value these tag-return data indicate that the Gulf of Gabès is a major wintering and foraging area for Loggerheads.

\subsubsection{Conservation measures}

\section{Zakynthos}

A 1984-1985 study by the Ministry of Environment, Physical Planning and Public Works (Margaritoulis, 1987a) proposed that the present core nesting area, comprising Sekania, Daphni and Gerakas beaches, together with the adjacent marine area for a distance of 500-600 $\mathrm{m}$ from shore, should be acquired and managed as a turtle sanctuary in conjunction with a rescarch and 
interpretation centre at Daphni. At the same time, a series of measures should be undertaken on Laganas and Kalamaki beaches, with the objective of limiting and controlling the effects of mass tourism. Such measures would include: prohibition of access after sunset, prohibition of all vehicles on the beaches, reduction in noise and 1 ight levels, control of boat activity, patrolling of the beach, and others. Collectively, these measures are the very minimum that must be taken to reduce current threats to the turtle population.

In response to growing concern over the pressures on the Zakynthos nesting population, the Minister for the Environment and Public Works issued a Ministerial Decision (No. 88208/3723/31.12.1981) on 29 January 1987 (Govt. Gazetle 37D/29-1-1987). The Decision defines zones for Controlled Residential Development, Restricted Building, a zone where turtle nesting beaches will be protected, and also includes various addilional measures for turtle conservation. No tourist development is permitted in protected areas; housing is controlled under strict building regulations. Where tourist development is permitted, regulations exist for the size, height and capacity of buildings. No lights are allowed on nesting areas or at sea adjacent lo them. Nest beaches are closed at night, vehicular traffic is prohibiled. Sun umbrellas, deck chairs and pedallos are allowed on certain specified sectors. The local administration received 55 million drachmas (ca $\$ 42 C 000$ ) to implement the Decision.

A tri-Ministry Decision (No. 18670/777/29.2.1988) in early 1988 established a marine protected area in the eastern part of Laganas Bay (Govt. Gazette 137 B/10-3-88), comprising a core area of 2000 ha where all vessels are prohibited and no fishing by any means is allowed, and a buffer area of 13000 ha, with a speed limit of 6 knots.

Patrolling of nest beaches under the provisions of the Ministerial Decision, by local staff and by voluntecrs, appeared to significantly reduce disturbance on Sekania, Daphni and on Marathonissi during the course of the 1987 season (Venizelos, 1987). Some nests laid on East Laganas and Kalamaki beach, and considered at risk, were transplanted to a small hatchery plot.

However, as Venizelos (1988, 1989) and others (Anon. c) have stressed, the turtle conservation situation on Zakynthos has changed little for the betler since 1987 and still gives rise to grave conrern. Massive tourist development planned for the western sector of the bay, and the existence of a zone of low and medium density building around virtually the entire remainder of the bay, will increase pressure on nesting and foraging turtles. 1llegal building and other developments, including on Daphni beach (second in importance to Sekania) have continued virtually unhindered while the Ministerial Decision has been in force. The provision for purchase of land in order to avoid disturbance to nesting turtles has not yet been implemented; funds received from the EEC carnarked for Caretta conservation have remained untouched. The situation has been aggravated by conflicting local interests and frequent. changes in key administralive staff, both locally and in central Government.

The Standing Committec of the Convention on the Conservation of European Wildife and Natural Habilats (Bern Convention), acting on the advice of a group of experls set up to advise on marine turtle issues, approved during their meeting in December 1987 a Recommendation (No. 9) concerning the protection of Caretta in Laganas Bay This document recommended to the Greek Government a number of general and specific measures that must be taken to 
maintain the critically important Caretta population within their care. As of late 1989, the majority of those reconmendations had not been implemented (Anon. C, 1989).

Greece has ratified the Bern Convention, but with regard to Loggerhead nesting at Laganas Bay, is not adequately fulfilling the obligations thereby assumed (Anon. c, 1989).

\section{General}

A long-term tagging and beach monitoring programme was initiated in 1982 by the Ministry of Coordination, with financial assistance from WWF, and continued by the Ministry of the Enviconment in cooperation with Greck Universities and the sea Turtle Protection Society of Greece (STPS), with co-financing from the EEC. Since 1988, tagging and monitoring has been undertaken by the sTPS with assistance from the EEC, the Ministry of the Environment and WWE. This project covers Zakynthos, parts of the Peloponnesus, and Rhodes. The sTPs has run a Public Awareness programme on Zakynthos since 1987, in conjunction with the prefecture, the Ministry of the Environment and WWF (Project 3825 Grecce), and an education programme for schoolchildren.

\section{Legislation}

Three marine turtle species (Caretta caretta, Chelonia nydas and Dermochelys coriacea) are included on the list of prolected species under Presidential Decree No. 67/1980 issued by the Ministry of Agriculture. Decree No. 617/198 prohibits fishing for sea turtles, and the collection or destruction of eggs and hatchlings. Law 1335/1983 ratifies the Convention on the Conservation of European Wildlife and Natural Habitats (Bern Convention). See 3.7.6. above for note on planning legislation at Zakynthos.

\subsubsection{Miscellaneous}

Average straight line carapace length of turtles measured in south-east Cephalonia during 1987 (Sutherland, undated): $78 \mathrm{~cm}$; average curved carapace length: $83.4 \mathrm{~cm}$; average weight: $67.26 \mathrm{~kg}(\mathrm{n}=40$, range $52.5-87 \mathrm{~kg}$; average clutch size: $115.5(n=22)$; average incubation (1985 season. Whitmore, $C$. pers. comm.): 59.6 days; overall hatching success: $47 \%$.

Females nesting at Kiparissia Bay in 1987 averagod $78.58 \mathrm{~cm}$ straight line carapace length (range 69-91 cm); $83.14 \mathrm{~cm}$ curved carapace length (73-98) (Margaritoulis, 1987b). Mean clutch size: 117.7 ( $n=52$ ) (Margaritoulis, 1988a). Females nesting at Zakynthos in 1978. 1979 averaged 80.4 cn curved carapace length (range c. 70-94 cm) (Margaritoulis, 1982).

\subsection{ISRAEL}

\subsubsection{General remarks}

In the late nineteenth century, Caretta was reportedly not uncommon of the coast of the wider Palestine region (Tristram, 1888, cited by Flower, 1933); according to Hornell (1935), Chelonia mydas was present seasonally in considerable numbers off the northern coast. The past extent of nesting is uncertain; very few sea turtles nest at present on Israel's Mediterranean coast. Ten nests were reported in 1984,14 in 1985, and 17 between Haifa and 
Caesarea in 1986 (Kuller, in litt., 23 November 1986). Overall, some $5-20$ nests, mostly Caretta with just a very fow Chelonia, appear to be laid annually (Mendelssohn, in litt., 1 August 1988; Kuller, in litt.; Ashkenazi and Sofer, 1988).

\subsubsection{Nesting sites and numbers: Loggerhead Caretta caretta}

During the 1950s, Sella (1982) found some 15 nests per km each season on the $5 \mathrm{~km}$ stretch of coast between Rosh-Haniqra and Nahariya, north of Acre and close to the Lebanon border; a similar density was found on the $8 \mathrm{~km}$ beach at Atlit, just south of Haifa. Only occasional nests were seen on the remaining $400 \mathrm{~km}$ coastline of Israel and northern sinai. These estimates indicate that around 200 Caretta nests may have been laid annually in the 1950s. There is no information on nesting during earlier decades.

In 1964 nesting density had decreased lo around three and one nests per $\mathrm{km}$ at Rosh-Haniqra and Atlit, respectively; a total of 26 nests on the $13 \mathrm{~km}$ of nesting beach (from data in Table 2 in Sella, 1982). Some 100-150 nests were observed during a rapid 1968 aerial survey (Sella, 1982). Of the 10-20 nests reportedly laid in Israel each year during the 1980s, most are Caretta (Kuller, in litt.).

\subsubsection{Nesting sites and numbers: Green Turtle Chelonia mydas}

According to an aged fisherman interviewed by sella, nesting occurred on all sandy beaches in northern Israel during the 1920 s and 1930 s (Sella, 1982). There appears to be no independent verification of this information, which should be treated with appropriate caution; nesting in northern Israel during this period does not appear to be documented in available literature. It is notable that Hornell (1935), whilst discussing the former turtle fishery, made no mention of turtle nesting nor of turtles being taken from nest beaches instead of at sea; there may have been little or no chelonia nesting of significance during the 1920 s and 1930 s within the bounds of present-day Israel (see section 3.10., Lebanon). In the 1960s, only scattered nests were round, at Netanya, Caesarea, Atlit, Nahariya and Rosh Haniqra (Seila, 1982). of the 10-20 nests reportedly laid in Israel each year during the 1980s, only a few are Chelonia (Kuller, in litt.).

\subsubsection{Population trends}

Information noted above suggests a decline in the number of female caretta nesting each season from around 70 in the 1950 s to a maximum of 50 and a minimum of perhaps 10 in the 1960 s (assuming three clutches each per season). In 1979 only two nests and seven non-nesting emergences were recorded on $250 \mathrm{~km}$ of coast (Sella, 1982). In recent years only some 10-20 nests of both species have been laid on Israel's Mediterranean coast, mostly Caretta and a few Chelonia (Mendelssohn, Kuller, in litt.).

Although the Green Turtle Chelonia mydas is virtually absent as a nesting species in Israel, the former population size is unknown and the magnitude of the apparent decline in nesting numbers cannot be assessed.

\subsubsection{Turtles at sea}

As noted above, Caretta was reportedly not uncommon off the coast in the late ninetecnth century (Tristram, 1888, cited by Flower, 1933), and Chelonia mydas was present seasonally in considerable numbers off the northern coast, according to Hornell (1935). An aged fisherman interviewed by Sella (1982) 
believed that Chelonia nydas migrated northward in spring, through the fishing grounds off Acre, toward the Turkish coast where nesting was assumed to occur. Reportedly, the turtle fishing season extended from April to July, said by sella (1982) to be the mating and nesting season in the area. Hornell (1935) reported that large numbers of Chelonia were to be found off the north coast between Acre and Abu Zabura (near Hedera) "during the hot season", when they came inshore to feed upon sea grass in the shallow waters (and on fruit or refuse discarded at sea during loading oporations). It is not entirely clear whether the "hot season" referred to by Hornell corresponds to the April-July period mentioned by Sella's informant. Hornell stressed the seasonal appearance of turtles, suggesting that the Chelonia previously exploited in Palestinian watcrs were migrants moving between nesting and feeding sites; in the absence of definitive evidence for former mass nesting in Israel, it is possible that most were part of the population nesting in Turkey, which was subject to heavy exploitation in later decades (see Turkey account).

\subsubsection{Threats}

\section{Exploitation}

The severe decline in turtle nesting in Israel is attributed by sella (1982) primarily to over-exploitation, especially during the 1920 s and 1930 s but also during the previous century, and aggravated in recent decades by removal of sand from nesting beaches and general disturbance.

The existence of an international trade in sea turtles from the Eastern Mediterranean to Egypt and Fingland was noted by Gruvel (1931). Lortet. (1883) reported seeing several hundred turtles, which he identified as Caretta, cast upon the shore at Haifa after a violent storm; Sella (1982) speculated that these may have been nesting females, but considered it much more likely that they were harvested specimens being collocted prior to export.

Hornell (1935) reported that "for several years past" all but some 200 out of nearly 2000 Green Turtle Chelonia mydas caught annually off palestine had been exported to Egypt, but this export trade had ceased by the time of his writing owing to the imposition by Egypt of high import duty. This indicates that the turtle fishery in northern Israel was mainly confined to the 1920s. The turtles were caught by means of a specially strong, large meshed seine made of flax; 120-200 $\mathrm{m}$ long, $10 \mathrm{~m}$ deep, with a mesh size of 30-40 cms. Hornell (1935) recommended that efforts be made oither to re-open this trade, to export to London, or to open a canning factory locally.

Relying on information obtained in the 1960 s from an aged risherman who had operated a turtle fishery in the 1920s and early 1930s, sella (1982) estimated that a minimum of 30000 turtles were harvested of the shores of present-day northern lsracl during this period. This total catch corresponds

approximately to a mean of some 2000 turtles annually, in agreement. with Hornell's estimate. The fisherman in question employed up to 12 crews, each with two boats, during the period April-July. Every specimen caught would be taken, amounting to a maximum of some 600 turtles daily, $90 \%$ being Chelonia nydas. An additional, but unknown, harvest was presumably also taken by other fishing crews organised by different masters.

Although this commercial utilisation would certainly have had an impact on the target population, the nesting sites used by that population are not known with certainty. It is possible that the fishery was based on a population that formerly nested in northern Isracl, but is now effectively extinct; it is 
perhaps more likely that some or most of the turtles taken were derived from the nesting population on the Mediterranean coast of Turkey.

The turtle fishery continued into the 1960s, although it ceased during World War II, and was based only on occasional catches for the domestic market until the end of the 1960s, when it stopped altogether (Sella, 1982). Turtles are still sometimes caught in trawl nets; if still alive when the net is hauled such turtles are released, or otherwise the shell may be preserved as a curiosity (Pisanty, in litt., 28 August 1988). The frequency of incidental catch is not known. Marine turtles are protected in Israel and have not been fished intentionally in recent years ( $P$ isanty, in litt.).

\section{Habitat disturbance}

The major nesting beaches at Nahariya, Rosh Haniqra and Atlit were severely damaged by removal of sand for concrete production between 1954 and 1963. Beach rock was exposed on the stretch between Nahariya and Rosh Hanigra, while at Atlit a stretch of some $80 \mathrm{~m}$ was removed from the beach, originally $120 \mathrm{~m}$ in length. Other beaches were also damaged, and at the same time an increasing number of turtle emergences resulted in no nesting, or in failed clutches due to flooding by sea water (Sella, 1982). Sand excavation was ended around 1970 and some improvement in beach condition became apparent after five years. Although Israel has no isolated beaches, all being subject to human activity (Kuller, in litt.), disturbance may not be a major threat to the present vestigial population.

\subsubsection{Conservation measures}

Sea turtles are protected species and hunting is prohibited by law; two nature reserves include beaches formerly important for nesting; a head-starting programe is in operation (Sella, 1982). Between 1979 and 1984, clutches were re-located and incubated artificially; owing to lower hatching success, this is now only done where nests are in danger from flooding or other disturbance (Ashkenazi and Sofer, 1988).

\subsection{ITALY}

\subsubsection{General remarks}

The Loggerhead Caretta caretta, Green Turtle Chelonia mydas and Leatherback Dermochelys coriacea have been reported in Italian waters (di Palma, 1978; Bruno, 1978). Very little nesting occurs at present, all by Caretta.

Although Bruno (e.g. 1978) has reported apparent nesting by Dermochelys, following discovery of two young individuals on a beach at Macconi (Gela Province) on the south coast of sicily in september 1961, and of eggs in the same area in June 1967, others (e.g. Argano, 1979) doubt that nesting occurred.

\subsubsection{Nesting sites and numbers: Caretta caretta}

Very sporadic and erratically-distributed nesting by Caretta is known, or suspected, at scattered localities in southern parts of the mainland (Ionian coast), Sardinia, Sicily, and on Lampedusa (Argano, 1979; di Palma, 1978; Bruno, 1978). There is some evidence (for example, museum collections of recentily-hatched juveniles) that nesting was formerly more widespread on the mainland, and that numbers were higher at some sites, including Lampedusa and sicily. There is, however, no evidence whatsoever that nesting ever occured on a large scale. 
Nesting is now extremely sparse and erratic; only a very few isolated nests have been recorded in recent years. Lampedusa appears to be the only regular nesting beach known, but only one or two nests are laid annually.

\subsubsection{Mainland}

Some nesting has been reported in the past on the lonian and Apulian coasts of southern 1 taly, but adequate documentation appears to be lacking, and no recent records exist (Argano, 1979). No trace of nesting was found at seven sites recently surveyed an the lonian coast (Argano and Cocco, 1988).

\subsubsection{Sardinia}

Some nesting has been reported in the past on the west coast, but documentation appears to be lacking, and no recent records exist (Argano, 1979). It is suspected, largely because of the frequency with which Caretta are caught just offshore, that some nesting may take place in the Golfo di Orosei area on the east coast (Voesenek and van Rooy, 1984).

\subsubsection{Sicily}

Although Argano (19/9) considered the southern coast of sicily to be the area in 1 taly of greatest interest for potential turtle nesting, in particular Eraclea-Siculiana beach west of Agrigento and Macconi beach east of Gela, he found no turtle tracks during several days survey.

More recent intensive surveys around the southern coast of sicily, from Mazara del Vallo east to Gela, have found evidence for only occasional isolated nesting (Argano and Cocco, 1988). Surveys of numerous beaches on the north, east and south coast in 1985, 1986 and 1988 revealed no evidence of nesting, although reports exist of Caretta nesting many years ago at all the sites visited (Gramentz, in litt., 17 October 1988). Nesting occurred on Linosa until a decade or so ago (Di Palma, in litt., 27 september 1982).

\section{9 .2 .4 . Lampedusa}

Only one or two nests appear to be made annually on Conigli beach, Lampedusa (Gramentz, 1986a). There is some evidence for a decline in the number of females nesting on Lampedusa, from 1940-1950, when large numbers reportedly nested on all beaches on the island (Conigli, Cala Croce, Cala Guitgia and Cala Francese), to the present decade, when nesting has virtually ceased (Argano, 1979; Gramentz, 1986a).

\subsubsection{Population trends}

Overall, marine turtles appear to be declining although still found more or less commonly in Italian waters, but nesting (Caretta) has virtually ceased in mainland Italy and the islands (Argano and Cocco, 1988). However, no good historical records exist to allow the severity of population decline to be measured; nesting does appear to have been somewhat more widely distributed in the past, and perhaps less sparse, but this is impossible to assess in the absence of documentation.

\subsubsection{Turtles at sea}

Numerous specimens of Caretta exist in museum collections, or are reported in the literature, originating from many localities around the entire Italian coastline (Bruno, 1978; Capocaccia, 1966), including the Isole Pelagie, Isole 
Egadi, Isole Eolie and Sicily (di Palma, 1978). Substantial numbers of foraging Caretta occur in southern Italian waters, mainly around Sicily, the Gulf of Taranlo, and the coast of Calabria (De Metrio and Megalofonou, 1988).

Argano (1979) cited information he had received that a large aggregation of turtles was observed in the Tyrrhenian sea in July 1960; the sienificance of the gathering is not known.

Eight of some 600 Caretta tagged orf south-east Italy have been recaptured; three in the Adriatic (north Italy, north Yugoslavia, Albania); two off Tunisia (Gulf of Gabès, Gulf of Tunis); and one each from central-west Italy, Malta, and west Peloponnesus (Cocco, pers. comm., January 1988; Argano and Cocco, 1988).

One long distance international tag return has recently been reported (Manzella et al.. 1988), and is of outstanding significance in being the first individually documented case of an Atlantic turtle moving into the

Mediterranean basin (and providing a record of long-term survival of a head-started sea turtle). This turtle, a Loggerhead, was collected as a hatchling from a Florida nest beach in 1981. It was head started in Galveston and released as a yearling of Padre Island in June 1982. At the time of release, it weighed $546.2 \mathrm{~g}$ and measured $14.4 \mathrm{~cm}$ in carapace length, $12.1 \mathrm{~cm}$ in width (Schroeder, in litt., 12 December 1986, to R. Argano). At the time of recapture, four years later in August 1986, it was in good condition and weighed $9 \mathrm{~kg}$ and had a carapace length of $43.5 \mathrm{~cm}$ (whether straight or over-curve measure unknown) and width $41 \mathrm{~cm}$ (Manzella et al., 1988). The turtle was caught on a drift long line intended for swordfish, some 10 miles south of Santa Maria Leuca in south-east Italy, at the mouth of the Adriatic.

Small numbers of Caretta are captured accidentally throughout the year by fishermen in the central-north Adriatic (in contrast to the southern Adriatic-Ionian sea, where large numbers are caught, but rarely during the winter). Turtles caught in the winter months in the central-north Adriatic are found in a state of apparent torpor in areas with a muddy substrate; this region may be of importance as an over-wintering or "hibernation" zone (Argano and Cocco, 1988).

Loggerheads tagged while nesting in Grecce have been recovered in the north Adriatic, Gulf of Taranto and in Sardinia (Margaritoulis, 1988a).

\subsubsection{Threats}

\section{Incidental catch}

There is significant catch, mostly incidental, in the Adriatic and acound sicily and Sardinia, and dead Caretta are occasionally but regularly washed up on south Italian beaches. Some of the Caretta catch is not incidental; Di Palma (1978) noted that a specialised fishery operated in the Isole Eolic (Lipari) north of sicily, catching an estimated 500-600 turtles annually (presumably mostly or entirely Caretta). The present fishery situation in these islands is not known. For the period 1978-1981, it has been estimated that approximately 250-1000 Caretta were taken annually in the Gulf of Taranto, mostly by the albacore fishery (De Metrio et al., 1983). The reported catch in 1982-1986 was lower, but the data appear unreliable (De Metrio and Megalofonou, 1988). Although most turtle catch is accidental, in many coastal settlements some of those caught are utilised, and are prepared according to local recipes (Argano and Cocco, 1988). Turtle meat is 
considered a delicacy and is still much sought after along the Ionian coast of Apulia (De Metrio and Megalofonou, 1988).

A recent project supported by WW' Italy has captured, marked and released around 600 Caretta; nearly all these specimens were recovered from fishermen, most had been hooked on swordfish long-lines (Argano and Cocco, 1988). More than 375 turtles were handled in 1986 alone. Activity has been concentrated off the Apulian coast of south-east Italy, where good relations have been developed with local fishing communities. Most catches occur between May and october, with a peak in July-August (when seas are calmest and fishing trips take place nearly every day).

Along the Ionian coast of Calabria alone, each trawler catches between three and 50 Caretta per trip, for a total annual catch of 16000 in the area (De Metrio and Megalofonou, 1988). Some of this very large total is likely to be comprised of turtles caught on more than one occasion, but the total mortality probably reaches a few thousand at minimum.

It is known that large numbers of Caretta are caught accidentally by fishermon in Sicilian waters (Cocco, pers. comm., January 1988), and around Sardinia, where turtles may be sold to restaurants or the carapace sold to tourists (Ballasina, pers. comm., January 1988). The fishermen have not cooperated with turtle workers, and little information is available on the magnitude of the turtle catch in these areas. One worker familiar with the area (Gramentz. in 1itt., 17 October 1988) has estimated that more than 5000 turtles are caught annually by Sicilian fishermen, and at least 1000 of those are killed; also that 150-300 turtles are killed around Lampedusa, out of a total catch of perhaps three times that number. Although turtles hooked on long-lines are usually thrown back after cutting the line, sometimes they are decapitated in order to save the hook (Gramentz, in litt., 17 october 1988). The percent mortality among turtles caught on long-lines is not known, but thought to be significant, death being caused by starvation or internal bleeding from the gut at the site of hook impaction. Mortality among turtles caught in trawl nets, mostly small to medium size specimens, was around $30 \%$ in one study (De Metrio and Megalofonou, 1988).

Japanese vessels using floating nets cause substantial mortality in cetacean and turtle populations in Italian waters (E. Balletto, pers. comm., 21 May 1990).

\section{Habitat disturbance}

Development for tourism, industry and agriculture has seriously affected a great many beaches, including those reportedly used formerly by nesting turtles. For example, Macconi beach, near Gela in southern sicily, is probably no longer suitable for turtle nesting, following construction of oil refineries nearby and of greenhouses and tourist houses close to the beach (Argano, 1979; Bruno, in 1itt., 1986). Loggerheads (apparently nesting) have not been seen since around 1970 at Imera, near Buonfornello on the north coast of Sicily; the beach here used to be around $100 \mathrm{~m}$ wide but removal of sand for construction and swamp reclamation has reduced it to $12-15 \mathrm{~m}$ (Gramentz, in litt.).

\section{Pollution}

Pollution is also affecting turtles in Italian waters. One $40 \mathrm{~cm}$ Caretta was found drifting about $200 \mathrm{~m}$ off the north coast of Lampedusa, partially immobilised by oil contamination; the turtle was cleaned and released 
(Gramentz, 1986b). According to Ballasina and Frisenda (pers. comm., December 1988), recent reports in the Italian press refer to the finding of hundreds of dead adult Caretta on beaches in south Italy. Death was allegedly attributed in these reports to pollution derived in part from the agrochemical industry. Reportedly (Ballasina and Frisenda, pers. comm., December 1988), such mortality has been a regular occurrence in recent years. Margaritoulis (pers. comm. Sept. 198/) reported that some 200 turtles had been washed up on the southern Adriatic coast of Italy in 1986; it was speculated that pollution was the primary cause of death.

\subsubsection{Conservation measures}

Marine turtles in Italian territory are nominally protected under legislation dated 21 May 1980. Fishing, capturing, transport and commerce are pcohibited. "Progetto Tartarughe Marine", based at the University of Rome and supporled by WW- Italia, has been operating in sicily and south-east italy since 1986. This project has included beach surveys and the collection, marking and release of Caretta caught by fishermen.

\subsection{LEBANON}

In the late nineteonth century, Caretta was said to be not uncommon of the coast of the wider palestine region, and was seen brought in by fishermen at Sidon (Tristram, 1888, cited by Flower, 1933). According to Lortet (1883) sea turties, which he identified as Caretta caretta, were reasonably comnon along the Levant coast, where they could be seen browsing on algae along rocky shores, and in groups floating near the surface of clear waters in southern "Syria" (corresponding to present Lebanon). He recorded seeing very large specimens around the mouth of the Nahr el Kelb (between Jounie and Beirut), around Ras el Abiad (Cap Blanc, between Tyre and Sidon), and in the region of Tyre. A few decades later, Gruvel (1931) noted that Caretta was present along the Lebanese coast, but in lower numbers than further north in the Gulf of lskenderun. Lortet (1887) estimated large individuals to be between 1.5 and $2 \mathrm{~m}$ in length; this appears greatly exaggerated (even if the head was included as well as the carapace), perhaps less so if the turtles were chelonia rather than Caretta.

It is uncertain to what extent marine turtles nested in Lebanon in the past. Lortet (1883) noted taking a mating pair of Caretta from the beach at Tyre, and further (1887) specified that this took place during the night on a sandy beach extending south from Tyre (perhaps within the boundary of present israel). He reported that the local camel-drivers, who hastened to cut the turtles throats, often found pairs in this situation. The fishermen at Tyre reported (Lortet, 1887) that the hatchlings emerge only in July (suggesting nesting in May), and rush to the sea immediately. Thesc observations appear to confirm that nesting did occur in the past, although the finding of coupled pairs on the beach seems anomalous. No nesting is known at present and turties are now recorded very rarely in Lebanese waters (Kouyoumjian, H.H., in litt., 16 september 1988). Although general legislation for the protection of wildife exists, it is not enforced at present and there is no specific legislation for marine turlles (Kouyoumjian, H.H., in litt., 16 september 1988).

\subsection{LIBYA}

A small Caretta population is known to nest on beaches within Kour National Park (Cyrenaika) (Schleich, 1984); 60-65 nests were recorded in each of two 
recent seasons, perhaps representing some 20. 30 females annually. Jackal predation on turtles and nests is high, and human disturbance is increasing. Tracks of Caretta have reportedly been seen on beaches near Al Quarahbulli (= Garaboli ?) some $60 \mathrm{~km}$ east of Tripoli (Bruno, pers. comm., cited by Fretey, 1987). It is probable that nesting occurs at other siles but no precise information is available. There are indications that at least one major nest area exists, and there are imporlant sea grass beds, comparable to the Gulf of Gabès (Jeudy de Grissac, pers. conm., October 1989).

A female Loggerhead tagged while negting in Grecce has been recovered off Libya (Margaritoulis, 1988a).

\subsection{MALTA}

\subsubsection{General remarks}

Five species have been recorded from Maltese waters: Caretta caretta, Dermochelys coriacea, Chelonia nydas, Eretmochelys imbricata and Lepidochelys kempi i (Brongersma and Carr, 1983). Caretta remains relatively common, Dermochelys has been recorded on several occasions, whilst Chelonia, Eretmochelys and Lepidochelys are known from single records (Brongersma and Carr, 1983; Gramentz, in litt., 1988).

\subsubsection{Nesting sites and numbers: Loggerhead Caretta caretta}

Although Caretta formerly nested at Ramla il-Hamra Bay in Gozo, nesting has ceased, following development and disturbance from tourism; the last recorded nesting occurred in the early 1940s (Balzan, in litt., 22 August 1988;

Lanfranco, in litt., July 1988; Baldacchino, in litt.. 11 August 1988). No information is available on the size of the former nesting population. Despotl (1915) reported that Caretta "has been known" to nest on unfrequented beaches, especially on Gozo; this suggests that nesting was probably minor, posibly irregular, and that Gozo was not the only site.

\subsubsection{Turtles at sea}

According to Despott (1915), Caretta was very common around Malta. Relatively large numbers of foraging Caretta still occur in Maltese waters; highest numbers are reporled between June and september, coincident with maximum fishing activity for swordrish, tuna and dolphin fish (Balzan, in litt.). Turtles are not infrequently observed basking at the surface or beneath palm leaves used for fishine floats (Balzan, in litt.). Some Caretta tagged on Zakynthos (Greece) have been recaptured in Maltese waters (Margaritoulis, pers. comn.).

\subsubsection{Threats}

\section{Exploitation, Incidental catch}

Earlier this century (Despott, 1915), large numbers of Caretta were taken at sea between August and November, and the species was used as food by the majority of the population. At present, many Caretta are caught by fishermen, both as a target species and incidentally during tuna and swordfish. long-lining or in nets. An estimated 1000 to 2000 Loggerheads are caught annually (Balzan, "Zghazagh ghall-Ambjent", in litt.). Gramentz (in litt.) 17 October 1988) has estimated that 2000-3000 Caretta are caught on long-line hooks during the swordfish season (spring-summer) around the Maltese Islands, and that 500-600 Caretta are killed each year. At one village, Gramentz 
bought, tagged and released 101 Caretta during one summer. If these various estinates are accurate, mortality is around $15 \%-50 \%$ of the total catch. Fishermen catch basking turtles with large hooks. Incidental catch in nets is increasing as the use of trawlers increases (Balzan, in litt.). Although turtles hooked on long-lines are usually thrown back after cutting the line, sometimes they are decapitated in order to save the hook (Gramentz, in litt.).

Turtles caught are used mainly for food but also for carapace preparation. They are typically left alive until sold, when they are killed by decapitation. Turtles fetch $£ 3$ to $£ 8$ (US\$9-24) according to size; most Loggerheads caught weigh $40.60 \mathrm{~kg}$, although smaller turtles are also caught, and some weigh up to $75 \mathrm{~kg}$. Turtle meat is used quite frequently in homes but less commonly in restaurants (Balzan, in litt.). Carapaces are sold for ornaments and tourist souvenirs (Lanfranco, in litt.; Cassar, in litt.. 8 August 1988). Flower (1933) recorded his surprise at being offered turtle soup prepared from Caretta during two dinner parties at the former Governor's Palace.

\section{Pollution}

A number of Caretta in Maltese waters have been observed contaminated by tar (Gramentz, 1986b) and with plastic and metal litter (Gramentz, 1988). Twenty out of 99 Caretta examined in 1986 (after being caught aceidentally on swordfish long-Iines) were found to be contaminated, 17 of these with crude oil, and a few with discarded plastic or metal objects (Gramentz, 1988). The typical diet of Caretta consists of molluscs, crustaceans and fishes; the only plastics seen in the gut or faeces of the turtles examined were transparent or white, suggesting that they were probably ingested by mistake for jellyfish (Gramentz, 1988). The effect of oil pollution is not known in detail, although small specimens can clearly be immobilised and exhausted by heavy contamination (Gramentz, 1988). Some turtles showed no external signs of oil pollution, but were seen to be contaminated after examination of the mouth cavity or faeces.

\subsubsection{Conservation measures}

Local conservation groups, including Zghazagh ghall-Ambjent and the Society for the Study and Conservation of Nature, have been campaigning for legislative protection of sea turtles in Malta and to reduce the present turtle fishery. According to Lanfranco (in litt.), the Government response is encouraging, and the Minister for the Environment has indicated that steps will be taken (Balzan, in litt.). A move to protect Ramla Bay did not meet with approval. Neither marine turtles nor turtle habitats are protected by legislation.

\subsection{MONACO}

The beach area is of recent artificial construction and no nesting occurs; Caretta occurs in adjacent waters.

\subsection{MOROCCO}

\subsubsection{Nesting sites and numbers}

No marine turtle nesting is confirmed to occur on the Mediterranean coast of Morocco, and nesting of any significance appears most improbable. 
Although one source suggested that both Caretta caretta and Chelonia nydas nest on the Mediterranean coast of Morocco, in April--September and

July-November, respectively (Aouab Taha and Moumni Amina, in litt., 4 July 1988), this is not confirmed by Laurent (1989a). Laurent surveyed a sample of beaches, interviewed $\mathrm{f}$ ishermen and others, and examined relevant literature dating back to the middle of the nineteenth century. He observed no evidence of nesting activily during his beach surveys in June and July. Among many persons interviewed, only one recalled having seen a presumed turtle track in the past ( 15 years ago, at Ras el Ma). Laurent found no first-hand reports of nesting in the historic or recent literature, and no documented reports.

Although suitable sandy beaches are present, relatively low water temperatures linked with the current regime of the western Mediterranean probably inhibits turtle nesting, as may also be the case in spain and Algeria.

\subsubsection{Threats}

Laurent (1989a) estimated, after interviews with many rishermen, that in excess of 3000 Caretta are captured (including re captures) by swordfish long-liners based in Moroccan ports. Many turtles are released at sea, but there is a significant local sale of carapaces to tourists, and of meat and carapaces to Spanish residents of Morocco; some carapaces are exported to Spain (this minor international trade appears to be unique among Medilerranean countries). Most incidental catch appears to be associated with the ports of Nador and Al Hoceima in central Morocco, on the south side of the Alboran Sea (Laurent, 1989a).

\subsection{3: Conservation Measures}

There is no protective legislation in force (Laurent, 1989a).

\subsection{SPAIN}

\subsubsection{General remarks}

Most available information concerns the Balearic Islands, whose waters hold large numbers of Caretta, mainly of sub-adult and adult size. No recent nesting is known on the mainland of spain, and there is no indication that. significant numbers nested in the past. There are records of very occasional nesting on the Mediterranean coast of the mainland in the 1920s, and a small number of museum specimens of very young Caretta, but sand temperatures may bo generally too low for optimum incubation conditions, and intense littoral development now precludes significant nesting (Mayol, J., pers. comm., January 1988). One female Caretta, apparently in a healthy condition, was found on a beach near Malaga on 29 April 1986 (Caminas, 1988), suggesting that occasional nesting attempts could be made.

Little information is available on Spanish territories in North Africa (Ceuta, Mellila). Turties are harvested for consumption, apparently in small numbers, and there is a minor trade in carapaces (Heredia, B., pers. comm., October 1989).

\subsubsection{Turtles at sea}

Spanish waters support substantial numbers of foraging or migrating turtles, mainly Caretta, and fishermen are reportedly familiar with Dermochelys (Mayol and Castello Mas, 1983). 


\subsubsection{Threats}

\section{Incidental cetch}

There is a very large incidental catch around the Balearics, by fishermen longlining for shark and swordfish (Mayol and Castello Mas, 1983). Some crews are based in the Balearics, but nost are from mainland spain and take their catch back to the peninsula; they operate in the islands between February and Seplember, and work the Gibraltar area or in the Atlantic at other times of year.

Each line can include 1000 to 1500 hooks, baited with bluefish or squid, and 3-10 (average 5.7) turtles are caught accidentally each day by each crew. All fishermen agree that Caretta is most common from the end of May but has become more rare in sunmer. Most Caretta are caught in May August, which largely coincides with the period of greatest fishing activity (Caminas, 1988). Given that around 80 boats have becn operating in recent years, the total incidental catch of turtles may be estimated at 16000 to 17000 each season (Mayol and Castello Mas, 1983). Recent investigaiions by the Spanish Oceanographic Institute have confirmed that 17 000-20 000 sea turtles are caught in the Balearic sea. This very large figure includes a significant, but as yet. unknown, proportion of recaptures (Sagarminaga, pers. comm., 1988), and the actual mortality caused is uncertain.

There is said to be a large incidental catch of turtles by swordfish long-liners in the Alboran Sea (Caminas, 1988). Nearly half of the Spanish swordfish catch in the Mediterranean is landed at Alicante, and based on data from this port, Caminas (1988) estimated that 7478 and 8389 Caretta were caught and released in the region in 1986 and 1987, respectively (it is not clear whether these estimates refer to the Alboran sea, the Balearic Sea, o: both).

The fishermen generally release turtles by cutling of the tip of the hook on which it is caught, and the turtle is often released with this part left embedded in the mouth or throat. Survival is thought to depend on the soverity of the wound so caused. Smaller hooks seem to cause the highest mortality, and fishermen are tending to use smaller hooks because the swordfish resource is overfished (Mayol, pers. comm., January 1988). In one experiment by $\mathrm{J}$. Mas (reported by Caminas, 1588), of six Caretta hooked, only one died; the remainder later ejected the hook and were liberated alive. Turtles not released are sold to restaurants, in markets, or sold to tourists as prepared carapaces (for 300.1500 peselas) (Mayol and Castello Mas, 1983).

\subsubsection{Conservation measures}

Further studies on the incidental catch problem in the Balearic sea are under way (WWE Project 3803 spain), including data collection and investigation of means necessary to minimise incidental catch and increase survival of hooked turtles (Mayol, pers. conum., 1987). Marine turlles are nominally protected in Spain under Decreto 3181 .

\subsubsection{Miscellaneous}

Most Caretta caught on long-lines around the Balearics are between 30 and $65 \mathrm{~cm}$ in straight-line carapace length, with a distinct majority between 45 and $55 \mathrm{~cm}$ (mean 49.5 , range $20.75 \mathrm{~cm}$ ) (data from Mayol and Castello Mas, 1983). Mean curved carapace length $52.6 \mathrm{~cm}$. This sample thus includes mostly sub-adult turtles, together with a few far from naturity and a fow probably mature animals. 
Little information is available. Lortet $(1883,1887)$ reported that sea turtles, which he identified as Caretta caretta, were reasonably or very common along the Levant coast, where they could be seen browsing on algae along rocky shores. It had been reported to Geldiay (pers. conm., 2 september 1987) that large numbers of turtles occur in syrian waters, and there is significant nesting. On the other hand, an aged fisherman, familiar with turtles in the eastern Mediterranean in the 1920s and 1930s, and intervicwed by Sella in the 1960s (Sella, 1982), did not know of any nesting in syria (sce section 3.8., Israel). Turtles were captured frequently and exported to Egypt until 1960, some 200.250 per month in that year; many fewcr are now caught (Laurent, 1989b).

\subsection{TUNISIA}

\subsubsection{General remarks}

Baccar (in litt., 17 August 1988) reports that four species have been recorded in Tunisian waters: Caretta caretta. Chelonia mydas, Dermochelys coriacea, and Eretnochelys imbricata (no documentation of this last is available). Recent analysis (Laurent et al., in press) confirms the regular presence only of Caretta, while Dermochelys and Chelonia are recorded on occasion (the latter was formerly less rare). Records of Caretta cited by Loveridge and Wiliams (1957) include: Bizerte, Gabès, Tunis, sfax market.

Little information on nesting is available; no well-documented records of past. nesting exist. According to Argano (1979), the north coast of Tunisia is of no special interest with regard to turtle nesting, but the east coast is the most important area for turtle nesting in the entire western sector of the Mediterranean coast of North Africa. This evaluation seens correct, insofar as there is no regular nesting in Algeria or Morocco (Laurent, 1989a) but sparse Caretta nesting in Tunisia (Laurent et al., in press).

\subsubsection{Nesting sites and numbers: Caretta caretta}

The Loggerhead is the only species to nest in Tunisia. Results of recent beach surveys in the north and south-east (Laurent et al., in press) indicate that nesting is extrenely sparse (the north-east sector of the coast has yet to be surveyed). Only one nest from which the hatchlings had recently emerged (on 1 september, indicating nesting at the end of June or early July), and one prescrved hatchling from another site, were found during a survey of $900 \mathrm{~km}$ of coastline, comprising $40 \%$ of the available beach length. No nesting tracks were observed. The direct evidence of nesting was found on the larger of the two Iles Kuriates ( $15 \mathrm{~km}$ off the coast near Monastir) and on the mainland beach between Ras Dimass and Mahdin ( $25 \mathrm{~km}$ south of Monastir). Reports from local fishermen suggested that some nesting occurred regularly on the Kuriat islands, perhaps $2-5$ nests annually, and may be regular on the mainland beach. Local sources also suggested that nesting occurred on the beach between El Bibane and the frontier with Libya, at Ghannouch, and on Thapsus (or Ras Dimass island). Several beaches were considered to be potential nesting sites, but have not yet been surveyed. According to Baccar (in litt., 17 August 1988), Caretta nests at Cap serrat (north Tunisia) and in the Golfe de Gabès (south Tunisia). Gramentz (in litt., 26 July 1988) reports that nesting occurs near Nabeul in the Golfe du Hammamet.

According to Laurent et al.. (in press), the present Caretta nesting population, apparently very minor, was certainly larger in the past; this 
cannot be directly substantiated. The suspected decline is atlributed to the capture of turtles at sea, the taking of eggs and females from nest beaches, and the increase in tourist development during the past 15 years (Laurent et a1., in press).

\subsubsection{Turtles at sea}

The Green Turtle Chelonia mydas was reportedly not unconunon in southern Tunisia during the early decades of the present century (sources cited in Laurent et al.. in press), but is now rare. Only three of 120 carapaces examined during Laurent's survey were from Chelonia mydas; the many fishermen interviewed appeared not to know the species although fish traders in the Bab Jebli market in sfax were familiar with it, and claimed to receive one specimen every two or three years (Laurent et al., in press). The apparent decline in the numbers of this species in Tunisian waters is probably a simple result of the collapse of nesting populations in the eastern Mediterranean.

One of the few recent specimens of Chelonia was reported at Sfax (March 1987) and had been tagged on Cyprus (laurent et al., in press); it was presumably a menber of the small population nesting in the Lara area where the Cyprus turtle conservation programme has been in operation (see Cyprus account).

Laurent et al. (in press) report that Caretta occurs in relatively large numbers around the coast of Tunisia. Numbers are known to be high in the Gulf of Gabès, a vast shallow water area holding some of the most extensive sea grass beds in the Mediterranean. Earlier literature sources suggest that numbers were highest in the spring; this may have represented a population nesting on Tunisian beaches. Most turlles are now taken by trawlers during the winter. It may be that fewer turtles are present in spring afler decline of a former Tunisian nesting population, or it may be that more turtles are being discovered in winter now that bottom-trawling has been widely adopted since the $1960 \mathrm{~s}$.

The majority of tag relurns from the creek nesting population of Caretta come from the Gulf of Gabès (Marearitoulis, pers. comm., 2 september 1987), caught during the winter months. Loggerheads captured at sea, tageed and released off south-east Italy have also been recovered in this area and in northern Tunisia (Argano and Cocco, 1988). The large numbers of Caretta present, and the tag return evidence, confirm that the Gulf of Gabès is a critical habitat for Mediterranean Caretta, apparently mainly during the non-nesting winter period.

\subsubsection{Threats}

\section{Incidental catch}

Very large numbers of Caretta are harvested, mainly for domestic consumption; a significant proportion is used in preparation of tourist souvenirs. Argano and Baldari (1983) estimated around 1500 captures annually. The recent survey by Laurent and colleagues (Laurent et al.. in press) indicates that 4000 5500 Caretta are taken in the Gulf of Gabès incidental to other fishing activities, primarily by the demersal trawl flect operating out of sfax during winter. Perhaps 20-30\% of the total turtle catch is taken by other fisheries, using swordfish long-lines, tune seines, and other nets and lines (Laurent et al. in press). Eggs and occasionally a nesting female are taken from nesting beaches. 
Turtles captured accidentally in trawls are typically alive when brought aboard, but all are taken for food (Laurent et al., in press). Turtle meat is a traditional part of the diet in many towns and villages in south-cast. Tunisia; it is sold at a lower price than fish and is used primarily by the poorest sectors of the communily (Laurent et al.. in press). It is considered to have a high therapeutic value (Lanteri, 1982). Turtle oil is sometimes used for medicinal purposes; turtle heart and blood were formerly attribuled special properties. The chief market is Bab Jebli in sfax. Carapaces are usually discarded; very few were seen on sale to tourists. Harvest of this magnitude seens certain to have a severe impact on Mediterranean turtle populations, and the feasibility of ending or reducing turtle utilisation should be investigated. During winter 1989-1990 the turtle harvest has reportedly been very much reduced; in advance of anticipated national legislation the local council has strongly discouraged the sale of turtles at sfax and fishermen have been returning turtles caught to the sea (Nefzi Tarek, pers. conm., 21 May 1990). Reporledly, most turtles are alive when returned, and national turtle consumption is very low (Nefzi Tarek).

Turtle consumption was also recorded by early twentieth century writers and late nineteenth sources, and appears to be a long-standing practice; turtles were in the past taken incidental to other fisheries, although they were also hunted with harpoons and siezed while resting at the surface (Laurent et al.:-, in press).

Dermochelys is said to be used for food and medicinal purposes (Baccar, in litt.): Dermochelys is very rarely utilised for such purposes elsewhere, so further data on use in Tunisia would be of interest.

\subsubsection{Conservation measures}

There is no national protective legislation in force although according to Laurent et al. (in press) the Commissariat Général à la Pêche published note No. 1155 on 10 June 1987 , calling upon the regional authorities to promote a ban on the turtle fishery, as called for under the terms of the $19 / 7$ African Convention, of which Tunisia is a party.

\subsection{TURKEY}

\subsubsection{General remarks}

On available information (which is incomplete for central and eastern parls of the North African coasl). Turkey is the most important single countey in the Mediterranean as regards total numbers of nesting females per scason, and species diversily (both Caretta and chelonia nest). At the same time, tourist development is affecting much of the Meditercanean coast of Turkey, and plans exist for further developments at most important beaches.

Some turtle nesting occurs almost everywhere between Dalyan in the west, and the border with syria, in the east, wherever suitable beaches without excess disturbance are found (Baran and Kasparek, (2989a). The tolal length of beaches distributed along the Acgean and Mediterranean coastine of Turkey is about $600 \mathrm{~km}$. Most significant nesting takes place on 13 main beaches, $120 \mathrm{~km}$ in tolal length; less significant nesting occurs on another four beaches, some $19 \mathrm{~km}$ in length overall (Baran and Kasparek, 1989a).

Fieldwork carried out by Geldiay and his co-workers up to 1979 had covered five western and central sites between Dalyan and Alanya, totalling almost 
$100 \mathrm{~km}$ in length, and subsequent work in 19801982 covered much of the eastern coast between Silifke, Mersin, and Yumurtalik (Geldiay et al., 1982, Geldiay, 1984). The research procedures used have not been presented in detail.

The 1988 WW' EEC-DHKD project was the first comprehensive survey of the Turkish Mediterranean coast for turtle nesting sites; the primary objective was to locate nesting sites and to allow assessment of their relative importance (Baran and Kasparek, 1989a). The tracks of emerging females were counted on three separate occasions during the three months of field work. It is important to note that the published figures are not claimed to represent fresh tracks only (Kasparek, in litt., 8 December 1988), and the figures typically comprise tracks made during some unknown period and still visible on the beach. It is thus rarely possible to derive an estimate of nests made per night, and impossible to make a firm estimate of seasonal nesting numbers. To the extent that earlier tracks are likely to have become obscured between surveys, the figures will underestimate the actual nesling effort. Counts were more frequent at the two major Chelonia beaches (Baran and Kasparek, 1989a; Langeveld and Sariguil, 1988), and permit some estimate of nesting numbers.

Caretta is known to nest at several sites, from the Dalyan region eastward at least to Tuzla beach (between Kazanli and Akyatan in the Cukurova Delta region, used mainly by Chelonia), and $C$. mydas at fewer sites, from the Manavgat. Kizilot region of Antalya Bay eastward to Samandagi, near the border with Syria (Baran and Kasparck, 1989a; Geldiay et al.., 1982; Geldiay, 1984). Significant Cheionia nesting is lacgely restricted to Kazanli and Akyatan in the Cukurova Delta coast, south of Adana. It is not entirely clear to what extent the eastern Chelonia beaches are also used by Caretta; it appears (Geldiay, 1984; Langeveld and Sarigül, 1988) that virtually all nests are by Chelonia.

\subsubsection{Nesting sites and numbers: Caretta caretta}

Nesting has been recorded by Geldiay at Dalyan, Fethiye, Kas, Finike, Kumluca, Kemer, Antalya, Belek, Side, Alanya, Gazipasa, silifke and Mersin (Geldiay et al., 1982; Geldiay, 1984). Some nesting may have occurred, and may still occur, along the Aegean coast, and nesting certainly occurs at several sites on the Mediterranean coast not examined by Geldiay, but reported by Baran and Kasparek (1989a).

The sites discussed below are those regarded by Baran and Kasparek (1989a) as the most important nest beaches in Turkey.

\subsection{8,2.1. Dalyan}

Information on turtle emergence and nesting at Dalyan gathered during the 1987 season is broadly compatible with data presented by Gcldiay. The 1987 information has been collected by Riccardo Jesu (a research studont from Genova) and by a team organised by the Kavala Group. Jesu walked the beach for a variable period each night, with a confirmalory survey the next mocning. and recorded nests and non-nesting emergences. His operation commenced in June 1987, and thus omitted the earliest part of the nesting season. Data made available by Jesu are presented in Table 6.

If the mean figure of 4.8 nests per night for the 32 day period recorded by Jesu was maintained for 60 days in the main June July nest season, some 288 nests would have been laid, and perhaps 350 in total in 1987 (allowing for 
Table 6. Turtle emergence and nesting data, Dalyan Beach, 4 June-5 July 1987. This period represents about half the main nesting

season. Note: this information was collected by Riccardo Jesu (Genova) as part of an MSc project; the author is most erateful to $R$. Jesu for his kindness in making these data available.

Date

Total emergences

Emergence only

Nests

(no nest)

\begin{tabular}{|c|c|c|c|c|}
\hline June & 4 & 9 & 5 & 4 \\
\hline & 5 & 10 & 8 & 2 \\
\hline & 6 & 111 & 10 & 1 \\
\hline & 7 & 9 & 5 & 4 \\
\hline & 8 & 11 & 7 & 4 \\
\hline & 9 & 21 & 9 & 12 \\
\hline & 10 & 10 & 5 & 5 \\
\hline & 11 & 2 & 0 & 2 \\
\hline & 12 & 3 & 1 & 2 \\
\hline & 13 & 3 & 1 & 2 \\
\hline & 14 & 3 & 1 & 2 \\
\hline & 15 & 2 & 0 & 2 \\
\hline & 16 & 3 & 2 & 1 \\
\hline & 17 & 7 & 0 & 7 \\
\hline & 18 & 8 & 5 & 3 \\
\hline & 19 & 7 & 3 & 4 \\
\hline & 20 & 9 & 4 & 5 \\
\hline & 21 & 20 & 12 & 8 \\
\hline & 22 & 29 & 13 & 16 \\
\hline & 23 & 13 & 5 & 8 \\
\hline & 24 & 23 & 19 & 4 \\
\hline & 25 & 5 & 2 & 3 \\
\hline & 26 & 4 & 1 & 3 \\
\hline & 27 & 7 & 2 & 5 \\
\hline & 28 & 4 & 1 & 3 \\
\hline & 29 & 7 & 2 & 5 \\
\hline & 30 & 9 & 4 & 5 \\
\hline July & 1 & 26 & 18 & 8 \\
\hline & 2 & 9 & 4 & 5 \\
\hline & 3 & 11 & 3 & 8 \\
\hline & 4 & 1.2 & 6 & 6 \\
\hline & 5 & Is & 10 & 5 \\
\hline
\end{tabular}

Tota1:

Mean per night:

10

5.2

4. 8

Mean per kilometre per night (beach c. $4.5 \mathrm{~km}$ long):
$2: 2$
1.2
1.1 
Table 7. Caretta nesting at Dalyan, 1987-1989. See below for key to data sources.

Year

1987

1988

1989

Nests

$154^{\mathrm{a}}$

c. $300^{\mathrm{b}}$

$145^{c}$

$250^{c}$

Key: a 4 June 5 July data collected by R. Jesu; b estimate for 1987 total extrapolated from Jesu's data (see text); C data collected by Hacellepe University, cited by Sarigül (1989).

sparse nesting at each end of the season, in early May and in August). This is very close to the figure of 330 nests per season published by Geldiay et al., (1982). A seasonal total of 350 nests would correspond to around 17 nests per kilometre (given a beach length of $4.5 \mathrm{~km}$ ), and 117-140 nesting females (assumine a mean clutch number per season of 3 or 2.5 , respectively).

On the other hand, the mean figure of 4.8 nests per day of the season recorded by Jesu does not confirm Geldiay's (1984) estimate of more than four nests per day on each kilometre of beach; the 1987 data suggest a mean figure of only about 1.1 nests per day per kilometre. This discrepancy is not necessarily indicative of a decrease in turtle nesting at Dalyan; at many turtle nest beaches around the world, nesting numbers frequently vary markedly between seasons, and differences of an order of magnitude are not uncommon. However, it is certain that human activity on the Dalyan beach was excessive during the 1987 season. Not only have varying numbers of tourists visited the beach during the night in order to see turtles, following widespread national and international media attention, but several groups of researchers (with diffecent levels of competence) have been engaged in survey work involving the Dalyan area and nesting turtles. In these circumstances, it would be expected that a significant number of females would have been deterred from nesting at Dalyan in 1987 . It has been reported that disturbance was further increased during 1988 , caused both by tourists and certain turtle workers.

Sarigil (1989) reports that the Hacettepe University team counted 145 nests in 1988, and 250 during 1989 , equivalent to 56 per kilometre for the season.

The Dalyan-Lztuzu area was declared a Specially Protected Area in late 1988 (the adjacent Köycegiz Lake was subsequently included). The DHKD (Society for the Protection of Nature) and AGA (Aktions Gemeinschaft Artenschutz) carried out a beach protection project during 1989, including access management and public education.

\subsubsection{Sarigerme-Dalaman}

This beach, some $10-11 \mathrm{~km}$ long, is around $10 \mathrm{~km}$ (in a straight line) east of Dalyan beach. Preliminary observations in July 1987 (Groombridge, unpublished) at the western-most section of beach near sarigerme revealed no tracks, although local fishermen reported that nesting females and hatchlings had been seen regularly during at least the past seven years, and that turtles are frequently caught by accident in the area. This section is subject to heavy disturbance from a large tourist camp, and any nesting that does occur 
is probably very minor. Toward the east, two nests were found on $12 \mathrm{July}$ in a $1 \mathrm{~km}$ stretch in front of the airport and west of the Acisu mouth (in an area generally too stony for turtle nesting), and five nests (three opened by predators) in $1 \mathrm{~km}$ of beach east of the Acisu mouth (Groombridge, unpublished). Local informants reported that sea turtles nest in some numbers, but mostly on the far castern end of Dalaman beach.

The central section of beach, west of Dalaman Airport and in front of the Government State Farm, was visited by Kinzelbach and whitmore in early June 1987; around 19 sets of recent tracks were recorded (C. Whitmore, pers. conm.). Local informants confirmed that turtles do nest on this stretch, but that nests are subject to very heavy predation by foxes. Observations made during the 1988 survey further confirmed the particular importance of this section, extending for $3.8 \mathrm{~km}$ between the mouth of the Dalaman River and the SEKA papermill outflow; the adjacent section extending $1.9 \mathrm{~km}$ east to the mouth of the Acisu was also important (Baran and Kasparek, 1989a). Counts of tracks and nests extracted from Baran and Kasparek (1989a) are presenled in Table 8; these data allow comparison to be made between different sections of the Sarigerme-Dalaman beach, but do not permit an estimate of seasonal nesting numbers (see section 3.18 .1 ).

Current plans for tourism investment allow for most of the Sarigerme-Dalaman beach, except for a $1.5 \mathrm{~km}$ section in front of the airport, to be subject to tourist development, including hotel construction (Baran and Kasparek, 1989a). A large hotel complex was under construction in 1987 on a rock headland overlooking the western sector, and another complex overlooking the eastern stretch. Baran and Kasparek (1989a) reconmend that any future construction work be confined to the Sarigerme area, and that the more central beaches with most nesting activity be strictly protected. They also stress the need to control offluent from the stika papermill.

Table 8. Summary of nesting data collected on Sarigerme-Dalaman beach during 1988 survey (Baran and Kasparek, 1989a). In this and subsequent tabulations, figures in "Energences" column include nesting and non-nesting tracks.

Date Length $(\mathrm{km})$ Site Fimergences Nests

\begin{tabular}{|c|c|c|c|c|c|}
\hline \multirow[t]{2}{*}{24} & June & 3.8 & Dalaman River - SEKA outflow & 24 & 13 \\
\hline & & 1.9 & SEKA outflow - Acisu mouth & 5 & \\
\hline \multirow[t]{2}{*}{30} & June & & Dalaman River - SEKA outflow & 28 & \\
\hline & & & SEKA outElow - Arisu mouth & 20 & \\
\hline 11 & July & & SEKA outflow - Acisu mouth & 11 & \\
\hline 12 & July & & Dalaman River - SEKA outrlow & 31 & \\
\hline \multirow[t]{2}{*}{12} & August & & Dalaman River - SEKA outflow & 13 & \\
\hline & & & SFikA outflow - Acisu mouth & 4 & \\
\hline
\end{tabular}

Dalaman River - SEKA outflow counts during period: 


\subsubsection{Fethiye-Calis}

The northern section of beach some $4.8 \mathrm{~km}$ in length near Calis, conmencing about $5 \mathrm{~km}$ north of Fethiye, is ranked by Baran and Kasparek (1989a) as an important Caretta nesting beach. The beach is some $50 \mathrm{~m}$ wide, generally a mosaic of shingle and sand. Geldiay (1984) listed this area as a medi'um nesting density site, with 1-4 nests/km/night. Counts of tracks and nests extracted from Baran and Kasparek (1989a) are presented in Table 9.

There is heavy tourist use of the beach, mainly in the vicinity of a tourist camp at the north end of the central sector, and gravel is extracted from the northern sector (Baran and Kasparek, 1989a).

The site was listed in 1988 as a Specially Protected Area.

Table 9. Sumnary of nesting data collected on Fethiye-Calis north beach during 1988 survey (Baran and Kasparek, 1989a).

Date

Length $(\mathrm{km})$

Site

Ëmergences

Nests

25 June $\quad 1.0$
1.5
2.3

13 August

1.0

1.5
2.3
Northern sector

Central sector

Southern sector, to Calistepe

Northern sector

Central sector

Southern sector, to Calistepe

$\begin{array}{rc}3 & 3 \\ 23 & 19 ? \\ 19 & 18 ? \\ 0 & 0 \\ 52 & 50 \\ 11 & 10\end{array}$

Central sector total counts during period:

\subsubsection{Patara}

This $11.8 \mathrm{~km}$ long sandy beach is around $80 \mathrm{~km}$ east of Dalyan (measured in a straight line), south of Kumluova and Xanthos, and is bisected by the mouth of the Esencay River. The eastern half, between the Fsencay and Patara is relatively high and sandy, with a prominent slope above the tideline. According to Baran and Kasparek (1989a), this is the beach referred to as "Kas" in Geldiay (1984), and, with 1-4 nests/km/day, ranked by Geldiay as of medium importance. Casual observations made on the eastern end of the beach near Gelemis on 8 July 1987 revealed four fresh Caretta nests, plus two U-turns, in $1.5 \mathrm{~km}$ (Groombridge, pers. obs.); this section alone had at least as many fresh nests as the $4.5 \mathrm{~km}$ Dalyan beach was holding nightly on 5.12 July. Fixamination by binoculars of part of the cemaining $3-4$ km westward to the river showed numerous apparently fresh emergence teacks extending to the waterline. Much of the western half of the beach consists of rather silty and compacted sand, frequently very flat and low-lying. One old track, with no nest localed, was probably made by $C$. mydas; one of two further nests, by Caretta, had been opened and gulls had recently becn eating the exposed eggs. The eggs were below the water level. Much of the beach showed evidence of wind erosion, and, although aboul ten concentrations of empty turtie ege shells were found, probably indicatiug past nest sites, no further tracks were visible. 
Gramentz (in 1 itt., 13 August 1988) found that tourist activity had increased very greatly in the 1988 season, with more accomnodation available (a dozen pensions instead of the two present in 1987), and more facilities on the beach (and plans to asphalt the track leading to the beach). He also received a reliable report of egg-collecting. Barton (pers. conm., October 1988) also reported heavy tourist use of patara beach, with tractors driving up and down the beach carrying soft drinks for drink stalls. Large scale tourist development is currently under way in the vicinity of Gelemis.

Although stopped by military exercises that took place on the beach from 10 July onward, Dieter Gramentz was able to survey nesting activity cast of the Esencay between 7 June and 9 July. During 32 nights, 124 encrences were recorded, all Caretta, and at least 14 nests, mostly just east of the Esencay; eight females were tagged (Gramentz, in litt.). Counts of tracks and nests extracted from Baran and Kasparek (1989a) are presented in Table 10. Baran and Kasparek stress the extremely high proportion of non-nesting emerences. On a brief examination of the beach in July 1987, almost all tracks were on the eastern half of the beach (Groombridge, pers. obs.), whereas during the 1988 season, $60 \%$ of tracks were on the western half (Baran and Kasparek, 1989a). This possibly reflects increased disturbance in the east.

Patara was designated a Specially Prolected Area on 2 March 1990 by Goverument Gazette No. 20449 (Whitmore et al., in press, 1990).

Table 10. Summary of nesting data collected on Patara beach during 1988 survey (Baran and Kasparek, 1989a).

Date

Length $(\mathrm{km})$

Site

Ëmergences

NesLs

$\begin{array}{lll}10 \text { June } & 6.0 & \text { Eastern secto } \\ & 4.8 & \text { Western sector } \\ 26-28 \text { June } & & \text { Western sector } \\ 13 \text { July } & \text { Eastern sector } \\ & \text { Western sector } \\ 14 \text { August } & \text { Eastern secto } \\ & \text { Western sector }\end{array}$

Total counts during period:

114

\subsubsection{Finike-Kumluca}

This beach extends for some $20.5 \mathrm{~km}$ around Finike Bay. Geldiay (1984) suggested an average of more than 4 Caretta nests/km/day along the western section of the beach near to Finike, and $1-4$ Caretta nests $/ \mathrm{km} / \mathrm{day}$ in the eastern sector, nearer to Kumluca and Mavikent. Baran and Kasparek (1989a) rank the eastern sector as one of the most important Caretta nesting sites in Turkey. This stretch is mainly shingle, sand is predominant in the west. Huts used by local people during the summer months are the major human impact on the beach; these are concentrated in the eastern sector, but in total affect the equivalent of half the entire beach length (Baran and Kasparek. 1989a). Most people arrive in July, together with most household goods, cars, and domestic animals; the huts have an electricity supply from Mavikent. 
Because the huts are unoccupied during much of the nesting period, nesting itself is probably little discupted, although hatchlings are thought to be seriously affected by light pollution, the passage of motor vehicles and predation by domestic animals (Baran and Kasparek, 1989a). The Minislry of Tourism currentiy plans development on the eastern section.

Counls of tracks and nests taken from Baran and Kasparek (1989a) are presenled in Table 11. Most nesting occurred on the eastern sector, adjacent to Mavikent, and mostly in more central parts of this sector. On one occasion, counts were made on the major central-east beach on two adjacent days ( $27 / 28$ June); the figures for 28 June, indicating 21 tracks and 14 nests, presumably represent new energences from the night of $27 / 28$ June. On this assumption, densily was relatively high, at 5.6 nests $/ \mathrm{km} / \mathrm{night}$.

Table 11. Summary of nesting data collected on Finike-Kumluca beach during 1988 survey (Baran and Kasparek, 1989a).

Date

Length $(\mathrm{km})$

Site

Ėmergences

Nests

$\begin{array}{lr}13 \text { June } & 4.7 \\ & 6.2 \\ 27 \text { June } & 9.4 \\ & 11.5 \\ 28 \text { June } & 7.4 \\ & 2.3 \\ 16 \text { July } & 11.5 \\ 15 \text { August } & 4.7 \\ 16 \text { August } & 4.8 \\ 17 \text { August } & 4.7 \\ 17 \text { August } & 6.6 \\ 19 \text { August } & 3.7\end{array}$

Western sector (part)
Eastern sector (part)
Western sector
Eastern sector
Eastern sector (part)
Southern sector, to Calistepe
Eastern sector
Western sector (part)
Eastern sector (part)
Western sector (part)
Eastern sector (part)
Eastern sector (part)

$\begin{array}{rc}14 & 7 \\ 32 & 6 \\ 13 & 8 \\ 35 & 30 \\ 40 & 25 \\ 19 & 18 ? \\ 181 & 71 \\ 0 & 0 \\ 102 & 0 \\ 0 & 0 \\ 8 & 1 \\ 0 & 0\end{array}$

Eastern sector total counts during period:

\subsubsection{Belek region}

The coast between Antalya and side, some $30 \mathrm{~km}$ in length, includes several beaches where turtle nesting has been recorded; Geldiay (1984) treats three site; (Antalya, Belek/Serik, Side) separately, whereas Baran and Kasparek suggest that the whole coast be treated as a unit. According to Geldiay (1984), Antalya and Belek/Serik support more than four nests/kn/day, and Side 1- 4 nests. Data presented by Baran and Kasparek (1989a) suggest that rather diffuse nesting occurs at several places along this coast; selected figures are given in Table 12. On the $13.3 \mathrm{~km}$ Belek-Cakallik beach on 18 July, 45 nests ( 71 emergences) were thought to be either one or two days old; this is equivalent of about three nests $/ \mathrm{km} /$ day. According to Baran and Kasparek, Belek-Cakallik beach is called Belek beach by Geldiay, and Belek-Köprï Cayi beach is called serik beach. Most parts of this coast are affected by local and international tourist activity, beach vehicles, nest predators, and further developments are planned. 
Table 12. Summary of selected nesting data collected on the Belek coast between Antalya and Side during 1988 survey (Baran and Kasparek, 1989a).

Date Length $(\mathrm{km})$ Site Emergences Nests

$\begin{array}{lll}17 & \text { June } & 10.8 \\ 18 \text { July } & \\ 18 \text { June } & 13.3 \\ 25 \text { June } & \\ 18 \text { July } & \\ 24 & \text { August } & \\ 18 \text { June } & 8.5 \\ 19 & \text { July } & \\ 21 \text { June } & 6.6 \\ 19 & \text { July } & \\ 26 & \text { August } & \end{array}$

Lara-Aksu beach
Lara-Aksu beach
Belek-Cakallik beach
Belek-Cakallik beach
Belek-Cakallik beach
Belek-Cakallik beach
Belek-Köprï Cayi
Belek-Köprü Cayi
Nigit-Eerakende
Nigit-Perakende
Nigit-Perakende

23

24

42

31

71

17

18

65

22

38

12

$11 ?$
$13 ?$
$25 ?$
20
$>45$
15
11
34
13
32
5

\subsubsection{Kizilot region}

Baran and Kasparek (1989a) note that the western sector (Side east beach) has local concentrations of nesting Caretta unique among Turkish sites; important nesting by Caretta, and more rarely by chelonia, also occurs on the castern sector (Kizilot). Tourist developments affect much of side beach, and most turtle nesting was found in the less developed eastern portion, some in betweon huts used by locals during summer, and some in the adjacent. undisturbed beach extending east to the mouth of the Manavgat River. Kizilot west beach extends from the Manavgat River lo the Cactus Beach Hotel $1 \mathrm{~km}$ east of Kizilot. Seventy-five nests were recorded on 24 July, and, assuming no nests were counted twice, it may be assumed that these were made on the three nights betweon that date and the previous count on 21 July. This is equivalent to 25 nests per night on $7.7 \mathrm{~km}$, or 3.2 nests/km/night. This aroa is subject to sand and shingle excavation, local and international holiday activity, and two laree hotels were under construction in 1988. Substantial nesting also occurs on kizilot east beach, which is affected by hotel and recreational development.

Baran and Kasparek (1989a) strongly urge that parts of Side east, Kizilot west and kizilot east beaches should be managed as a strict nesting reserve.

Table 13. Summary of selected nesting data collected in the Kizilot region during 1988 survey (Baran and Kasparek, 1989a).

Date Length $(\mathrm{km})$ Site Emergences Nests

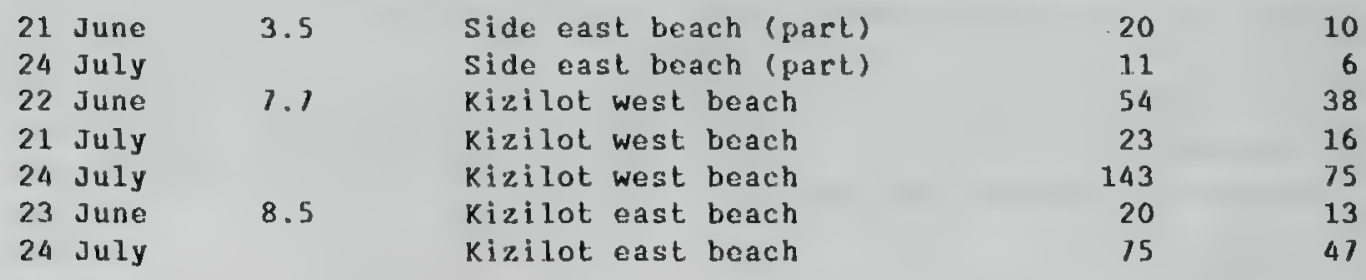




\subsubsection{Demirtas}

This $7.4 \mathrm{~km}$ beach is situated close to the small town of Demirlas. There is one hotel, modest holiday activity, and some sand and shingle extraction; the Ministry of Tourism docs not plan further development.

Table 14. Summary of nesting data collected on Demirtas beach during 1988 survey (Baran and Kasparek, 1989a).

Date Length $(\mathrm{km})$ Site Emergences Nests

15 June

$26 \mathrm{July}$

15 August
7.4

$4 \quad$ Demirtas

Demirtas

Demirtas
11

74

16
3

38

3

\subsubsection{Gazipasa Ciftlik}

About $1.6 \mathrm{~km}$ of this mainly shingle $2.4 \mathrm{~km}$ beach is suitable for nesting. There is no tourist activity, although the soulhern portion is used for sand and shingle extraction. Reportedly, some egg collecting occurred in the past, and it appears that turtles are sometimes killed, seemingly in order to take the carapace for decoration. Baran and Kasparek (1989a) consider nesting density, which appears to be mainly or entirely by Caretta, to be relatively high.

Table 15. Sumnary of nesting data collected on Gazipasa ciftlik beach during 1988 survey (Baran and Kasparek, 1989a).

Date

Length $(\mathrm{km})$

site

Emergences

Nests

16 June

1.6

Gazipasa Ciftlik

Gazipasa ciftlik

8

39

3

$26 \mathrm{July}$

28

\subsubsection{Göksu Delta}

This extensive wetland region is tordered by beaches some $22.4 \mathrm{~km}$ length in Lotal; most Lurtle nesting, mainly or entirely by Caretta, occurs on a stretch about $5 \mathrm{~km}$ long midway along the $10.5 \mathrm{~km}$ western coast. Silifke is the nearest large town, and this area might correspond in part to the silifke beaches discussed by Goldiay (1984). The northern 2-3 $\mathrm{km}$ of the west coast is used for tourism, with several holiday villages for Turkish people; the southern $3 \mathrm{~km}$ is very flat and often washed over by the sea. Some sand excavation occurs on the central portion used by turtles. Baran and Kasparek suggest that $36 \%(=30)$ of 84 tracks observed on 12 July probably dated from the previous night; use of the same percentage would indicate that about eight nests were made, giving a density of $0.8 \mathrm{nests} / \mathrm{km} / \mathrm{night}$. Most emergences did not resull in nesting.

The Göksu Delta was designated a Specially Protected Area on 2 March 1990 by Government Gazetle No. 20449 (Whitmore et al.. in press, 1990). 
Table 16. Summary of nesting data collected at Göksu Delta during 1988 survey (Baran and Kasparek, 1989a).

Date Lenglh $(\mathrm{km})$ Site kimergences Nests

21 June 10.5

$12 \mathrm{July}$

*Calculated from figures in Baran and Kasparek (1989a:99).

\subsubsection{Loggerhead nesting sites: a summary}

Considering only the Caretta sites for which Geldiay provides estimates of the number of nests per $\mathrm{km}$ per season (Dalyan, Kumluca, Side, Alanya), Dalyan is by far the most important. The density of around 70 nests per kilometre over the season (assuming the beach is $4.5 \mathrm{~km}$ in length, not. $\mathrm{km}$ as stated by Geldiay) is more than twice the density of about 30 recorded at the two most comparable sites. In his 1984 paper, Geldiay (Figure 9), stated that three other sites he investigated (Finike, Antalya and Serik) have a comparable daily nest density, all with in excess of four nests per day per season: The length of available nest beach, and the total number of nests per season, at these other sites are not presented, and so the number of nests per $\mathrm{km}$ per season cannot be calculated.

Unpublished data collected in 1987, and information gathered during the 1988 WWF EEC-DHKD survey (Baran and Kasparek, 1989a) indicate that several sites, in addition to Dalyan, hold significant numbers of nesting Caretta. None of the other sites has yet been adequately surveyed during the nesting season, and so none has data comparable to those available for Dalyan, first surveyed by Jesu and by the Kavala team in 1987 . The incomplete information at hand suggests that some of the nine additional beach areas ranked as major nesting sites by Baran and Kasparek (1989a) might have supported nesting numbers during 1988 comparable to those at Dalyan in 1987, although nesting density is very much lower at most.

Preliminary data tabulated in an interim project report (Baran and Kasparek, 1988) indicate that some 630 Caretta nests were recorded between Dalyan and the Göksu Delta in the period 29 May-18 July 1988; a mean of around 13 Caretta nests per night during 50 days. The major nesting effort was distributed over about 10 main beach areas. Because the earliest part of the nesting season was not covered, and many nests might have been missed between visits, this is likely to be a significant underestimate. These data are not tabulated in the final report (Baran and Kasparek, 1989a), but are consistent with figures given in the discussion of individual nesting beaches. Extrapolating rrom this figure, to reflect a nesting scason of around 110 days (mid May-late August), suggests a minimum of 1650 nests might have been deposited during the 1988 season; assuming three nests per female suggests that a minimum of 550 remales nested. Data in Geldiay et al. (1982) and Geldiay (1984) suggest, on the basis of similar assumptions, that around 1000 Caretta nested per season. It seems fair to assume that the average seasonal nesting contingent in Turkey is likely to be between the two extremes of 550 and 1000 females. 


\subsubsection{Nesting sites and numbers: Chelonia mydas}

Some Chelonia mydas nesting takes place alone cenlral and castern parts of Antalya Bay, or did so formerly (Geldiay et al.., 1982: 429, Fig. 3). Speciric locations include Belek beach ( $40 \mathrm{~km}$ in extent, at $36^{\circ} 50^{\circ} \mathrm{N}, 30^{\circ} 58^{\circ} \mathrm{E}$ ), Side $\left(30 \mathrm{~km}\right.$, at $\left.36^{\circ} 51^{\prime} \mathrm{N}, 31^{\circ} 28^{\prime} \mathrm{E}\right)$ and Alanya $\left(12 \mathrm{~km}\right.$, at $\left.36^{\circ} 36^{\prime} \mathrm{N}, 32^{\circ} 05^{\circ} \mathrm{E}\right)$. No C. nydas nesting has been found west of Belek, and Alanya was the eastern most sile reported. Subsequent studies in 1980-1982 (Geldiay, 1984: 72, Fig. 9) appear to have revealed no $\mathrm{C}$. mydas nesting at Belek or side, some nestine near Alanya, but more importanl nesting at Mersin. Tuzla, Karatas and Yumurlalik. The 1988 WW'-EEC-DHKD survey revealed that significant Chelonia nesting is largely reslricted to Kazanli and Akyatan on the Cukurova Delta coast, south of Adana, with some nestine at Samandagi, near the border with Syria (Baran and Kasparek, 1989a).

The sites discussed below are those regarded by Baran and Kasparek (1989a) as the nost important Chelonia nest beaches in Turkey.

\subsubsection{Kazanli}

Kazanli is situated some $10 \mathrm{~km}$ east of Mersin, near the western end of the very extensive Cukurova delta region, formed by the Tarsus (Berdan), Seyhan and Ceyhan Rivers, and located south of Adana. The delta lowlands, with a coast extending some $130 \mathrm{~km}$, have been settled relatively recently following reduction in the incidence of malaria. Kazanli beach is about $4.5 \mathrm{~km}$ long; a soda and a chrome factory are located behind the western-most $0.5 \mathrm{~km}$ stretch, which is separated from the next $0.5 \mathrm{~km}$ section by an effluent channel. The latter section is backed by low duncs with a bamboo fence, regularly advanced toward the beach, demarcating the marein of the irrigated arable delta lowlands, and is separated from the next section to the east by a beach shipyard area. The next section is also about $0.5 \mathrm{~km}$ long, and is separated from the final $2.5 \mathrm{~km}$ stretch by a holiday campine area used by local people.

Langeveld and Sariguil participated in the fieldwork in the Cukurova region, and provide (1989) a relatively detailed treatment of turtles and nesting (the figures presented by Langeveld and sarigül differ slightly from those published by Baran and Kasparek; for the sake of consistency the latter are tabulated here).

Baran and Kasparek (1989a) stress the several factors having an impacc on the Kazanli nesting beach. The bamboo fence behind the main nesting section is being shifted seaward and consolidated as a flood protection for the arable hinterland; this is critically reducing the width of beach available for nesting. There is substantial light pollution from the adjacent factories, both of which also discharge apparently untreated industrial effluent directiy into the sea, which is highly opaque and milky or milky-green in colour. Shrimp trawlers operate within $50 \mathrm{~m}$ of the beach. The beach is heavily littered with plastic waste and tar. Recreational use of the beach does not appear to have a critical impact on the main nesting section, although lights cause disorientation of hatchlings on adjacent sections.

According to Baran and Kasparek (1989a), local people remember participaling in the Chelonia fishery during the 1960s, when they would turn emerging females on the beach, to be loaded into the company lorry which came the next morning. Information gathered by sella (1982) sugecsts that the former turtle fishery (see below) had depleted populations near Mersin, presumably including Kazanli, by the mid-1960s, when turtle harvesting shifted eastward to the 
coast between the Seyhan and Ceyhan Rivers. It is conceivable that the relatively large Kazanli population is now recovering somewhat from heavy exploitation in the 1960s.

Table 17. Summary of selected nesting data collected at Kazanli beach during 1988 survey (Baran and Kasparek, 1989a).

Date Length $(\mathrm{km})$ Site Emergences Nests

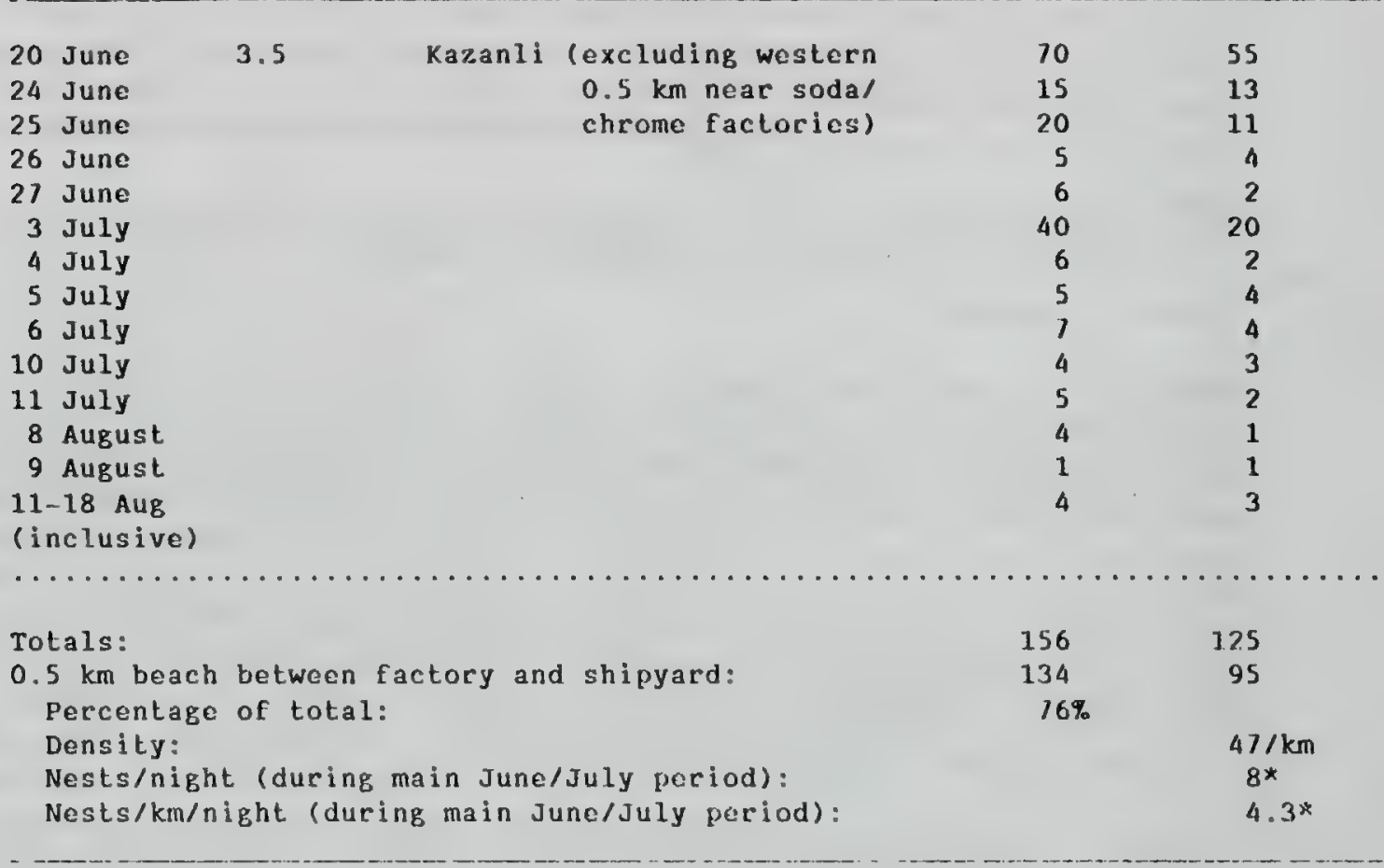

*These highly approximate figures are calculated from the partial June/July data tabulated above; they include nests already present on the beach on 20 June, but do not include the apparently decreasing number of nests expected after 11 July.

\subsubsection{Akyatan}

This $21.7 \mathrm{~km}$ beach extends along the south-west coast of the Cukurova Delta region, to its southern extremity in the vicinity of Karatas; the extensive Akyatan Gölui lies a few kilometres inland. Only some $4.5 \mathrm{~km}$ in the western sector is subject to tourist activity, the remainder is little used and appears only moderately affected by plastic and oil pollution.

Langeveld and Sarigül (preliminary report, 1989) peovide a more complete tabulation of data for Akyatan than Baran and Kasparek (1989a) give in their Lext; counts of tracks and nests extracted from Langeveld and sariguil are presented in Table 18. The total number of nests recorded on Akyatan beach is only slightly lower than the Karanli tolal, but nesting at Akyatan is distributed over a much greater length of beach; most occurs along the centeal sector. 
Table 18. Summary of selected nesting data collected at Akyatan beach during 1988 survey; data for a few dates on which partial surveys were made are excluded (Langeveld and Sariguil, preliminary report, 1989).

Date I.ength $(\mathrm{km})$ Site Fimergences Nests

$\begin{array}{rrrrr}2 \text { June } & 18 & \text { Akyatan (west and centre) } & 20 & 5 \\ 10 \text { June } & & \text { Akyatan (west and centre) } & 27 & 12 \\ 17 \text { July } & & \text { Akyatan (west and centre) } & 198 & 72 \\ 3 \text { June } & 5 & \text { Akyatan (east) } & 0 & 0 \\ 11 \text { June } & & \text { Akyatan (east) } & 7 & 1 \\ 22 \text { June } & & \text { Akyatan (east) } & 21 & >4 \\ 1 \text { July } & \text { Akyatan (east) } & 6 & 2 \\ 17 \text { July } & \text { Akyatan (east) } & 17 & 6\end{array}$

\subsubsection{Samandag 1}

Baran and Kasparek (1989a) rank this area as the thitd most important Chelonia nest site in Turkey. Much of the eastern shore of the Bay of Iskenderun is rocky; this 10.3 kn beach is located in extreme south-east Turkey, adjacent to the border with syria. Most nesting occurs along a $5 \mathrm{~km}$ stretch toward the south, between a holiday village and the mouth of the oronles River. Sand is extracted from the south end of the beach; the beach is heavily littered with debris, notably plastic waste.

Table 19. Summary of selected nesting data collected at Samandagi beach during 1988 survey (Langeveld and Sarigiil, preliminary report, 1989).

Date Length $(\mathrm{km})$ Site Emergences Nests

\subsubsection{Green Turtle nesting sites: a summary}

According to Geldiay (1984: 12, Fig. 9) there appear to be 1-6 C. mydas nests per kilometre per day of the nesting season at Alanya; fewer than one per $\mathrm{km}$ per day at a site a little to the east of Alanya; and noce than six nests per km per day at each of four siles - Mersin, Tuzla, Karatas and Yumurtalik. around Adana in the east. A precise figure for the length of all these beaches is not available, but extrapolation from these nesting rate estimates suggests that annual nesting numbers at the time of Geldiay's rieldwork (late 1970s, early 1980s) could have been in excess of 1000 females. However, details of the surveys on which these nesting density data are presumably based are not available, and some doubt has becn expressed over their accuracy.

Results of the 1988 WW'- E'EC DHKD beach survey indicate that significant Chelonia nesting still occurs on the Cukurova Delta coast, between Mersin and Yumurtalik, although numbers do not appear to be high. Langeveld and Sacigiul 
Table 20. Selected nesting data collected in south-east Turkey (Cukurova Delta and coast of Gulf of Iskenderun), 1988 (Langeveld and Sarigül, preliminary report, 1989). Sites are tabulated in west-cast sequence. Most rigures are rounded to nearest whole number.

Beach Nests \% of total Nests/km Nests/km/night period $\left(\operatorname{maximum}{ }^{1}\right) \quad\left(\max ^{2}\right)$

Kazanli (total beach) $\$ 16$

Kazanli (major sector) 85

Tarsus

Tuzla

Akyatan (total beach) ros

Akyatan (major sector) 71

Karatas

Agyatan

Yelkoma

Yumurlalik

Yumurtalik (east)

Dörtyol

15

12

1
29

283

24

7
Samandagi (total beach) 33

Samandagi (major sector) 33
11
.1

.04

.04

.38

.15

10.vi-17.vii

11.0

4-6.vi

$.27 \quad 19 . v i-30 . v i i$

1 Refers to maximum nests $/ \mathrm{km} / \mathrm{night}$ within survey dates, this is not necessarily the peak of the entire nesting season.

2 Indicates period during which maximum nesting effort was recorded.

Table 21. Summary of selected nesting data collected in south-east Turkey (Cukurova Delta and coast of Gulf of Iskenderun) between 25 May and 16 August 1988 (Langeveld and Sarigül, preliminary report, 1989).

Tolal beach lenglh surveyed:

Total nests located:

Possible number of nesting: females*:
$138 \mathrm{~km}$

297 ( +64 possible nests)

$300-350$

Major beaches:

$$
\mathrm{km}
$$

nests

\% of total

Minor beaches:

Kazan 1 i
Akyatan

4.3

116

105

Samandagi

Yumurtalik

Yumurtalik (E)

10
7
6.5

34

15

12

11

5

6.5

3

* Assuming three nests per female per season, and that each nests every third year. 
(1989) provide a useful discussion of the results collected by the eastern field team of this survey; selected data are sumarised in Tables 20 and 21.

A total of around 300 nests was recorded along this coast, mostly at Kazanli and Akyatan (Langeveld and Sarigïl, 1989; Baran and Kasparek, 1988). If it is assumed that each female deposits three nests during the season, and that each nests every third year, some 300 females might have been nesting in south. east Turkey in the 1988 season. The relatively minor nesting contingent indicated by these data is considerably smaller than the 1000 or so females per year suggested by Geldiay's 1979. 1982 data. In either case, Turkey is far the most important known $\mathrm{C}$. mydas nesting area in the Mediterrancan.

\subsubsection{Population trends}

\section{Caretta caretta}

Data from the 1988 WWF-FEC-DHKD beach survey (Baran ano Kasparek, 1989a) suggest a nesting contingent of Loggerhead Caretta caretta considerably smaller than that reported for 1979-1982 by Geldiay. It is possible that this to some extent represents seasonal fluctuation, or is an artefact of inaccurate data. The 1988 Caretta nesting data are difficult to interprel because it seems possible that a significant proportion of nests was not recorded; certainly, none of the Caretta beaches was surveyed as fully as the Kazanli and Akyatan Chelonia beaches. There is thus no hard evidence for a decline in nesting numbers, although this is suggested by the sparse data that are available. Given the increasing disturbance affecting most nesting beaches, mainly as a result of tourist developments, marked decline would be expected in the future if present sites are not safeguarded.

\section{Chelonia mydas}

There are no good historical data on nesting numbers prior to Geldiay's sludies which commenced in 1978, although it can be inferred that numbers were high. Baran (1987) stated that "large herds" came ashore to nest in the $1940 \mathrm{~s}$ and carlier. There appears to have been a massive decline in nesting numbers, although the evidence for this is mainly indirect.

Very large numbers of turtles, mainly or entirely Chelonia mydas, were harvested along the Mersin-Yumurtalik coast south of Adana betweon the early 1950s and mid 1960s, and fishermen interviewed in 1965-1967 reported chat much nesting occurred (Sella, 1982) (see section 3.18.6. below). The harvest has been estimated at some 2000 turtles annually (sella, 1982). The inference is generally made that the great number of Chelonia caught indicates the presence of a large turtle population nesting on adjacent beaches, but this depends on the mode of harvest; if turtles were caught mainly at sea, it is possible that a significant proportion was comprised of foraging turtles from nesting beaches in other countries. According to Baran (1987), turtles were collected in laree numbers on beaches around lskenderun in the the 1950s, and this turtle population, which at first appeared inexhaustible, had entirely disappeared within a period of $6-7$ years. Similarly, Baran and Kasparek (1989a) state that turtles were collecled from the nesting beach at Kazanli. on the other hand, Sella (1982) implied that the turlles wore taken at sea by fishing crews. Possibly both methods were used at different times and in different localities.

It does seem probable that most turtles exported from Turkey during this period, however obtained, were from local nesting populations; on this 
assumption, a massive decline in nesting numbers appears to have taken place between the 1950s and the end of the 1970s, when Geldiay's fieldwork was carried out. This is also suggested by the fact that the centre of the turtle fishery was forced to change location as local turtle stocks declined (Sella, 1982). In addition, some of the many thousand turtles caught during the 1920 s and 1930 s in waters orf present northern 1 srael may have belonged to the population nesting in south-east Turkey, and could have been caught during their reputed northward migration (Sella, 1982). Intensive harvesting for international trade purposes appears to have resulted in the near extirpation of the Turkish Chelonia population (Sel1a, 1982; Mendelssohn, 1983).

The very minor nesting that is indicated by 1988 data may represent a further recent decline in the Turkish Chelonia population, a seasonal variation, or an artefact of inaccurate earlier data.

\subsubsection{Turtles at sea}

\section{General remarks}

Lortet (1887) remarked on the abundance of Caretta (under the synonym Thalassochelys caouana) in the Gulf of Iskenderun (Gulf of Alexandria), where five or six at a time might approach a moored boat. Gruvel (1931) regarded the north-east corner of the Mediterranean, betweon the cilician coast of Turkey and the coast of Syria, including the Gulf of Iskenderun, as a major centre of sea turtle abundance. According to Gruvel, Caretta was by far the most common turtle in the eastern Mediterranean, while Chelonia and Dermochelys were relatively rare; the Logerhead was reportedly found in the Gulf of Iskenderun and the Gulf of Tarsus (south of Mersin) in particular, but also, less comonly, along the Levant coast. At present, Chelonia appears to be more common in this region than Caretta.

Loggerheads have been recorded along the Aegean coast of Turkey, and enter the Black Sea through the Sea of Marmara (Geldiay, 1984).

\section{Foraging/wintering sites}

There is firm evidence (Geldiay, 1984) for the presence of distinct aggregations of wintering Chelonia mydas in waters of $f$ south-east Turkey, suggested initially by the frequency with which adult-sized turtles could be seen surfacing to breathe (Geldiay, pers. conm., September 1987). Van den Berk et al. (1988) report seeing a group of 15-25 turtles in Yumurtalik Bay in April 1986, and two mating pairs of Chelonia on 5 April 1987. Van den Berk (in litt., 27 July 1989) twice crossed Yumurtalik Bay in the Gulf of lskenderun on 13 october 1988 and, in about 2 metres depth of clear water toward the east of the Cukurova Delta region, saw 30-40 sub-adult (estimated length $40 \mathrm{~cm}$ ) and two adult Chelonia, presumed to be feeding on the abundant Zostera sea grass beds. Fishermen reportedly saw marine turtles in the area every day. Less-mature animals, around $22-24 \mathrm{~cm}$ in carapace length, have also been observed in this area, and are said to be numerous in places along the Adana Yumurtalik coast, and to cause fishermen much difriculty (Geldiay, 1984). Baran and Kasparok (1989b) note that in the Cukurova Delta region the $10 \mathrm{~m}$ isobath is located from 1.5 to $6 \mathrm{~km}$ off shore, there is thus a vast area of shallow water over a rich alluvial substeate, suitable for marine plants on which Chelonia graze. These observations appear to contirm the findings of Gruvel (1933) (although he cited Caretta as the species involved) and indicate that the Gulf of Iskenderun is frequented by turtles outside the nesting season, including adults, sub-adults and smaller immatures. 
The importance of this crilical foraging area requires further investigation; this work is urgent because the area is greatly at risk from the oil and stecl industries located around Yumurtalik, and is already much affected by heavy shipping activities in the region.

Because imature and adult Chelonia consistently occur in the area, including during the winter months, Geldiay (1984) suggested that the Green Turtle population is resident. Geldiay (1984) also stated that the Caretta population does not leave Turkish Mediterranean waters. Baran and Kasparek (1989b) discussed the size and spatial distribution of stranded turtles recorded during the 1988 survey. All but one Chelonia were round between Mersin and the border with syria, mostly along the Cukurova coast, where most nesting occurs. The 26 specimens ranged from about 10 to $90 \mathrm{~cm}$ in curved carapace length; most were immatures of between 20 and $40 \mathrm{~cm}$. In contrast, most of the Caretta found were of sub-adult and adult sizes. Baran and Kasparek (1989b) conclude that Chelonia reside in waters adjacent to their nesting beaches in the Gulf of Mersin and GuIf of Iskenderun, while most Caretta disperse to more distant feeding grounds. It is not in fact known whether the nesting and wintering turlles are part of the same population, or whether (as in other parts of the world) the turtles seen in the area outside the breeding season actually nest at another location; the latter secms unlikely, given the sparsity of chelonia nesting in the region.

\section{Movements}

Gcldiay (pers. comm., September 1987) reported that a Caretta tagred at Dalyan was recaptured in Italian waters, and one was recaptured at Yenifoca, on the Turkish Aegean coast. Two Caretta tagged while nesting in Greece have been recovered in the latter area (Margariloulis, 1988). One Turkish tag appears to have been returned from the Marine Biology Laboratory at Eilat on the Gulf of Aqaba (Geldiay, pers. comm., September 1987), but this must be treated as unconfirmed (no details are available and it is not clear whether a turt.le tagged in the Mediterranean actually passed through the Suez Canal into the Red Sea, or whether a tag alone somehow found its way to Eilat).

\subsubsection{Threats}

Present turlle populations, of Caretta and Chelonia, are severely threatened by tourist development and suffer heavy natural egg predation; they are also adversely affected by incidental catch, and presumably by pollution (although there is little direct evidence).

\section{Exploitation}

Gruvel (1931) reported an extensive international trade in turlles, which he identified as Caretta. derived from the Gulf of lskenderun and adjacent waters, and destined for the turtle soup industry based in England.

Green Turties in Turkish waters have been very greatly depleted by past exploitation. According to sella (1982), similar numbers of turties were harvested of south cast Turkey, mainly during the 1960s, as were caught off what is now the coast of northern lsrael between the last world wars; this corresponds to a mininum of 30000 turtles, or around 2000 annually.

The intensive turtle harvest appears to have conmenced during the 1950s, and by the mid-1960s a fishing company had established a slaughtcrhouse at lskendecun to process turtles bought from fishermen operaling around Mersin. 
The entice production was destined for kurope. Mendelssohn (1983) attributed this commercial initiative, producing turtle soup, to "an enterprising 1scacli". In the main fishine season, between April and June, 200 or more turtles were brought to Iskenderun daily (Sella, 1982). The weight of these turtles was usually $120-150 \mathrm{~kg}$, suggesting that Chelonia mydas was the species caught.

In the dozen years between 1952 and 1965 , reportedly up to 1.5000 turtles were taken from the Mersin region alone. The turtle population had declined toward the mid-1960s when the main fishing activily moved easlward to the coast between the Seyhan and Ceyhan Rivers south of Adana. Here, 100 or more turtles (all Chelonia) were being caught daily in May 1965, by which time more than 10000 turtles had been taken in the area. Turtle fishing also extended to Yumurlalik, further to the east, where information collected in 1972 suggested that the annual catch at that time was around 1200 turtles (Sella, 1982).

According to Baran (1987), turtles were collected in large numbers at Iskenderun in the the 1950 s "as soon as they reached the shore, usually without being given a chance to lay their eggs"; he further reports that this turtle population, which at first appeared inexhaustible, had entirely disappeared within a period of 6-7 years (it is not clear whether Baran is referring to one local nesting population, or to Grecn Turtle nesting in general in south-east Turkey). Baran and Kasparek (1989a) note that locals at Kazanli remember turnine turtles on the nesting beach, to be collected by the fishing company. There appears to be little or no documentary evidence that turtles were also fished at sea, although sella (1982) implies that this was the case.

It is difficult to assess accurately the impact of this fishery on the Turkish Chelonia population. Present information is not complete, but the numbers nesting in 1988 appear to be far lower than suggested by data gathered by Geldiay in 1979-1982, and but a tiny remnant of the numbers present threc decados ago. It seems likely, as stated by sella (1982) and Mendelssohn (1983), that intensive harvesting for international trade purposes has resulted in the near extirpation of the Turkish Chelonia population.

\section{Coastal development}

Coastal development, mainly associated with international tourism, is the most acute and most widespread threat at present facing turtle populations in Turkey. The tourist industry, involving new facilities such as hotel accommodation, pensions, restaurants, roads, and new civil use of the airport at Dalaman, has increased rapidly and largely without control during the past few years. The rate of change in coastal habitats has been especially rapid in the mid-1980s, and tourist accommodation appears to have more than doubled between 1987 and 1988 in certain localities, such as Dalyan and Patara.

Further details are noted elsewhere in this country account, including section 3.18 .2 .

The coast between Mersin and Yumurlalik, the main Chelonia nesting area in the Mediterranean, has experienced a very rapid spread of toucist development in recent years; similarly, between the Göksu Delta near silifke, and Mersin, all beaches accessible from the land side have been developed, with hotels, pensions and camping sites (van den Berk, in 1itt., 23 August 1987). There is a large industrial zone east of Mersin, and a pipeline carrying waste from the industrial area at Tasucu (near silifke) enters the sea close to the good 
beach wesl of the Göksu Delta (van den Berk, in litt.). The extensive coastal plain south of Adana (Cukurova Della) is intensively cropped, mainly with cotton, and the offshore waters will presumably be receiving a heavy load of excess fertilizer and pesticide residues; the effect of such pollution on the turtle population is unknown. Recent information (Langeveld and Sarigül, 1989) suebests that the main Green Turtle nest area is affected by heavy metal pollution. The topography of this corner of the Mediterranean, combined with heavy ship teaffic, appears to facilitate extensive deposition of seaborne litter, especially plastic waste (as with many beaches on Cyprus).

\section{Incidental catch}

Fishermen at Yunurlalik interviewed by Van den Berk et al. (1988) reported regular incidental catch of turtles, both in nets and, most frequently, on long-line hooks. Sparse evidence suggests that adult chelonia are infrequently caught, small adult Caretta might be, but most catches are of large imnatures or sub-adults. Estimates of the number caught by a small group varied from 3-4 turtles a day to 30-40 a year.

\subsubsection{Conservation measures}

\section{Protected areas}

Followine protracted efforts made by the DHKD (Society for the Protection of Wildife) and others, the very important Caretta nesting beach at Dalyan was declared a Specially Protected Area (SPA) by the Turkish Government in late 1988. Multi-lingual signs at each end of the beach inform visitors of the importance of the beach, and state that access is not allowed in the hours of darkness and use of beach umbrellas is prohibited. In July 1988 no infrastcucture was apparent and no attempts to regulate access or restrict use of umbrellas were evident; the situation improved in 1989 with the implementation by DHKD and AGA of a managemenl and public education programme. Fethiye was also designated a SPA in late 1988. Threc additional sea turtle nesting areas on the Turkish coast, at the Göksu Delta, Patara and Ekincik, were designated as Specially Protected Areas by the official Gazelte of the Turkish Government, No. 20449, on 2 March 1990 (Whitmore et al., in press, 1990). These will now have the same protection as Dalyan and Fethiye, the two nesting areas designated SPAs in 1988.

The SPA designation now applies to five of the 17 areas identified as important sea turtle breeding areas by the DHKD-WWF-EEC survey of the Turkish coast (Baran and Kasparek, 1989a). The new protection status of SPA under Turkish law has yet to be fully aligned with the SPAs of the Barcelona Convention of which Turkey is now a signatory. The first Turkish SPA was created at Dalyan in 1988 before Turkey had ratified the Barcelona Convention. The official definition of the Turkish SPA designation requires that: (1) the natural resources within the area must be protected from negative impacts of human activity, (2) all development and management plans for the area must be revised, (3) the area will be managed in accord with international agreements and Turkish environmental law, (4) the Directorate or SPA will be fully responsible for all environmental issues within the designated area. The new SPA designations include a legal requirement that. all construction within the area must be halted and all physical planning revised as from 2 March 1990 (Whitmore et al., in press, 1990).

The task of ameliorating these problems will now be the responsibility of the newly formed Directorate of SPA in Ankara. The Ministry of Forestry is 
currently proposing to extend the area of its existing strict Nature Reserve (SNR) at Akyatan to include the turtle nesting and feeding area. The other undesignated 11 nesting areas are still under threat from development and often from large scale sand mining. However, in the official Gazetle of the State Planning Department of the Turkish Government (Reg. No. 0327, 1989) a committment was made to a long-term progranme to protect all of the 17 areas (Whitmore et al., in press, 1990).

Marine turtles might be expected to occur at sea adjacent to Dilek Peninsula National Park and Olympos Seashore National Park, but no nesting is known and no specific conservation measures are taken.

\section{General remarks}

The standing Committee of the Convention on the Conservation of European Wildife and Natural Habitats (Bern Convention), acting on the advice of a group of experts set up to advise on marine turtle issues, approved during their meeting in Decenber 1987 a Reconmendation (No. 8) concerning the protection of marine turtles at Dalyan and other important sites in Turkey. This document recommended to the Turkish Government a number of general and specific measures that must be taken to maintain the important marine turtle populations within their care. By late 1988, two of the recommendations made by the standing Committee had been partially implemented; Dalyan had been declared a protected area, and the authorities had undertaken to reassess existing plans for further tourist development at important sea turtle sites. A comnittment to reassess plans for tourist development along the

Mediterranean coast has been made; a WWF supported follow-up to the 1988 beach survey will operate during 1990 , providing technical advice on turtle beach management to various authorities.

Turkey has ratified the Bern Convention, and with regard to marine turtle populations under her care, has begun to make significant progress toward fulfilment of the obligations thereby assumed.

\section{Legislation}

The capture of all sea turtles is strictly prohibited (Fisheries Regulations; orficial Gazette, 28 February 1986). See above for specially Protected Area regulations.

\subsubsection{Miscellaneous}

Geldiay et al. (1982) reported that female Caretta nesting at Dalyan in 1978-79, and males caught at sea, ranged between $55 \mathrm{~cm}$ and $74.6 \mathrm{~cm}$ in straight line carapace length; average weight $57.5 \mathrm{~kg}$, range $40-15 \mathrm{~kg}$. Baran and Kasparek (1989b) record the mean curved carapace length of turtles measured while nesting during the 1988 beach survey: Chelonia, $90.1 \mathrm{~cm}$; Caretta, $15.6 \mathrm{~cm}$.

\subsection{UK: GIBRALTAR}

No nesting is known. Lanteri (1982) reported observations made by a sea captain (M. Alain Connan) in the region of the straits of Gibraltar: he recalled seeing aggregations of Loggerheads several years ago, which he considered were associated with reproduction (although he knew of no nesting beaches in the vicinity). Reporledly, sea turtles were much more common some thirty years ago (Connan, in Lanteri, 1982). (See sections on Aleeria and Egypl, above, for further examples of mass movement by marine turtles). 


\subsection{YUGOSLAVIA}

No nesting is known, and little is known of turtles in Yugoslavian waters. One Caretta, tagged and released after recovery from fishermen of $[$ south-east Italy, has been recoeded of northern Yugoslavia (Argano and Cocco, 1988). Two Caretta tagged whilc nesting in Grecce have been recovered along ti.e Yugoslavian coast (Margaritoulis, 1988). 


\subsection{The origin of Mediterranean nesting populations}

It is now well established that the Mediterrancan basin was isolated from the Atlantic Ocean during the Messinian stage of the late Miocene, between six and five million years before present (Hsü, 1972; Maldonado, 1985). This event appears to have been associated with global plate tectonic movements which constricted the straits connecting the Atlantic and the Meditercanean, and with a world fall in sea level. Evaporative water loss from the Mediterrancan greatly exceeds input from precipitation, but is offset by influx of Atlantic water over a sill at the straits of Gibraltar; obstruction of carlier straits, combined with a fall in sea level, prevented such influx and led lo desiccation of the Miocene Mediterranean. There is some controversy over the exact nature of Messinian environments in the basin (Maldonado, 1985; Pérès. 1985), but sedimentary evidence, namely the prevalence of sall evaporites and marls of brackish water origin, indicates that arid and hypersaline conditions prevailed, and that marine turtles would almost certainly have been extirpated from the region. They would have been able to nove back into the basin when normal marine conditions resumed at the Miocene/pliocene transition around five million years before present. If this interpretation is correct, present marine turtle populations nesting in the Mediterranean would be of Atlantic origin, and must be less than five million years in age. If a single colonisation event occurred for each present nesting species, study of genetic relationships could suggest the probable parent At lantic nesting colony (and the Messinian desiccation episode might contribute to establishine a timescale for molecular evolution in marine turtles).

\subsection{Nesting population size and trends: a comparison}

The present status of marine turtle populations in the Mediterranean has been shaped by centuries of minor local exploitation, followed by decades of more intense local exploitation combined with widespread disruption of marine and coastal habitats, and the massive impact of incidental catch; most are probably mere reminats of formerly more flourishing populations. The two key demographic factors in their survival are the number of hatchlings that reach the sea, and the number of these that attain maturity; data on these parameters are completely absent for all Mediterranean populations. The absolute size of nesting populations can be illusory; it is possible for mature females still to emerge to nest for soveral seasons, even though cohorts approaching maturily are diminishing progressively because of a collapse in recruitment, and the population may already be doomed to extirpation.

Current information on nesting sites is incomplete (see Tables 23-25 for summary). Laganas Bay (Zakynthos, Greece) is the only important site where useful data for a sequence of nesting seasons are readily available; similar information for the Lara beaches (Cyprus) has been collected but remains unpublished. Sparse information is available for central and eastern sectors of North Africa, but most of this coast renains unknown as regards turtle nesting; it is possible that significant nesting takes place.

In these circumstances, any assessment of the relative importance of known nesting sites must remain provisional. However, on present information, Laganas Bay in southern Zakynthos (Greece), with probably between 300 and 700 females per season in recent years, supports the largest single caretta 
nesting aggregation in the Mediterranean, several times larger than that based at Dalyan-tztuzu (Turkey), which until recently was considered the second largest. Survey work in summer 1988 has shown that Dalyan is more accurately regarded as one of 10 important Caretta sites in Turkey (Baran and Kasparek, 1989a). Only Turkey and Cyprus are known to hold significant numbers of nesting Chelonia, and numbers are very low in Cyprus.

The available information on population trends, reviewed in the individual country accounts above, indicales that without exception every country nesting population for which information is available is either significantly threatened, most often or most evidently by coastal development and international tourism, and/or is known to have declined during the present. century.

Most known declines occurred during the years after the World War Il. krance (Corsica), lsracl, Italy and Malta are now virtually without nesting turtles; Caretta formerly nested in all four countries, and Chelonia in $1 s r a e l$.

However, there is no hard numerical evidence that nesting populations in these four countries were ever large; with the possible exception of Israel, they might equally have been small and relatively unimportant. Although vestigial nesting still occurs in sicily, and one or two other parts of south italy and lsrael, there would seem to be little prospect of any increase in numbers in present conditions.

All known large nesting populations, particularly at Laganas Bay in southern Zakynthos (Greece), and along the southern coast of Turkey, are more or less severely threatened, particularly by tourist development. A very few populations, for example, the Chelonia nesting at Lara in west Cyprus and near Dipkarpaz in the north east, or the Caretta nesting around Kiparissia Bay in the peloponnesus, appear to be relatively undisturbed on their nestine beach (although both are sure to be affected by other factors such as incidental catch). It is essential that major nesting beaches, adjacent marine areas occupied by turtles during the nesting scason (mating arcas, inter-nesting habilat), and foraging grounds occupied outside the breeding season, are effectively protected.

There is particular concern for the Green Turtle population in the eastern Mediterranean, now nesting mainly on beaches in south-east Turkey. This population, still by far the largest known in the Mediterranean, has greatly declined since the immediate post world War II period, when large numbers reportedly nested and large numbers wore harvested. Data collected during 1979-1982 suggest that perhaps up to 1000 females may have nested at that time, but 1988 data indicate that only some threc hundred females nested, in which case recent decline has been rapid (however, the 1979-1982 data may not be reliable, and between season fluctuation in nestine effort may explain some of the apparent difference). The magnitude of apparent decline between the 1950 s and the present means that this population must be treated as critically endangered.

Overall, the conservation status of marine turtle populations nesting in the Mediterranean region is poor, and their long-term survival prospects are not favourable without the rapid implementation of rigorous protection and management measures. Although Mediterranean nesting populations are virtually insignificant in global terms (there are many nesting beaches elsewhere that each hold many times the number of Caretta and Chelonia nesting in the entire Mediterranean), they form a tremendously imporlant part of the European natural and cultural heritage, and efforts to secure their survival should be a matter of high priority. 
Table 22. Summary of size and trend of known past and present Loggerhead Caretta caretta nesting populations in the Mediterranean.

$\begin{array}{lllll}\text { Country } & \begin{array}{l}\text { Relative } \\ \text { population } \\ \text { size }\end{array} & \begin{array}{l}\text { Nests } \\ \text { ser season }\end{array} & \begin{array}{l}\text { females } \\ \text { per season }\end{array} & \text { trendation } \\ & & & \end{array}$

Algeria

Cyprus

south

north

E'gypt

France

Corsica

Greece

Zakynthos

All sites

Israel

Italy

Libya

Kouf N.P.

other sites

Malta

Morocco

Syria

Tunisia

Turkey

Dalyan

All sites apparently no regular nesting

small $75, \quad$ decline, threatened
small threatened

uncertain, possibly significant

extinct; formerly small population only?

$\begin{array}{lll}\text { large } & 857-2460 & 300-800 * \\ \text { large } & 1400-2500 & <1000 ?\end{array}$

virtually extinct; former size uncertain
10- $20^{1}$
$0.10 *$
decline

virtually extinct; fornerly small population only?
$1-2^{2}$
$0-10 *$
decline, threatened

small $60-65^{3} \quad>25^{3}$ ?

uncertain, possibly significant

threatened?

extinct; formerly small population only?

apparently no regular nesting

no information

very small?

?

decline?

moderate

c. 300 max.

$100 *$

large $550-1000^{4}$

threalened

threatened

Noles to Table 22: 1 estimate of 10-20 nests is for Caretta and chelonia combincd; 2 estimate for Lampedusa, the only known regular nest site; 3 data for Kouf National park only, no further data available; 4 lower estimate is based on imprecise data from 1988 survey, upper estimate is a rough approximation based on Geldiay's 1979-1982 work; both are subjecl to revision and the latter may be questionable.

Relative size estimates apply only in the Mediterrancan context; no Mediterranean populations are "large" by world standards. Lstimates of annual nesting numbers, with the exception of those marked with an asterisk (*), are informed guesses made on the basis of incomplete data. On present information it is impossible to take account of natural seasonal fluctuations in nesting numbers. Sec country accounts for details and sources. 
Table 23. Summary of size and trend of known past and present Green Turtle Chelonia mydas nesting populations in the Mediterranean.

$\begin{array}{llll}\text { Countiy } & \begin{array}{l}\text { Relative } \\ \text { population per season } \\ \text { size }\end{array} & \begin{array}{l}\text { Females } \\ \text { per season }\end{array} & \begin{array}{l}\text { Population } \\ \text { trends }\end{array} \\ \begin{array}{l}\text { Cyprus } \\ \text { Akamas area } \\ \text { north }\end{array} & \begin{array}{l}\text { very small } \\ \text { small }\end{array} & 25 & \text { decline, threatened } \\ \text { threatened }\end{array}$

Égypt possible nesting, no information

Istoael

$$
\begin{array}{lll}
\text { virtually } & 0-10^{*} & \text { severe decline } 1 \\
\text { extinct } & &
\end{array}
$$

Syria possible nesting, no information

\begin{tabular}{|c|c|c|}
\hline large & $\begin{array}{l}300-350^{2} \\
\left(<1000 ?^{3}\right)\end{array}$ & $\begin{array}{l}\text { severe decline, } \\
\text { threatened }\end{array}$ \\
\hline
\end{tabular}

Turkey

Notes: 1 It has been inferred that large numbers formerly nested, but evidence is sparse; 2 based on data from 1988 survey, ${ }^{3}$ a rough approximation based on Geldiay's 1979-1982 work; both these estimates are subject to revision and the latter may be questionable.

Relative size estimates apply only in the Mediterranean context; no Mediterranean populations are "large" by world standards. Estimates of annual nesting, with the exception of that marked with an asterisk (*), are informed guesses made on the basis of incomplete data. On present information it is impossible to take account of natural seasonal fluctuations in nesting numbers. See country accounts for details and sources.

Table 24. Estimates of total number of females nesting each year in the Mediterranean.

$\begin{array}{ll}\text { Caretta } & 2000 \\ \text { Chelonia } & 300-400 \\ & (<1000 ?)\end{array}$

Note: These are very approximate order-of-magnilude estimates, for comparative purposes only. They are based solely on known nest sites, on very incomplete data, and take no account of expected natural betwcen. scason fluctuations in nesting numbers. See country accounts for details and sources. 
Available evidence supecsts that sea turtles generally are highly philopatric: each season in which they nest (typically at two or three year intervals), females tend to return to the same strelch of coast that they firsl nested upon. They also show high site fixity: they tend to return to the sarne individual beach area. Within one season, all clutches tend to be laid un that same stretch of beach.. This means that once a nest beach is rendered unsuitable for turtle nesting, recruitment to the population formerly nesting on that beach will be reduced or terminated. Turtles at sea may be affected by calch and pollution, but this generally will be spread over various age classes and both sexes, and would thus be expected to have a less severe immediate impact on recruitment. In these cicumslances, nesting populations are unable denographically to reinforce one another and there is a greater need to conserve each individual population.

There is a good deal of evidence to support this model in the case of Chelonia mydas, but it is generally accepted, and there is some evidence for this, that Caretta shows less sile fixity when returning to nest, both between and within scasons, than Chelonia mydas (Bjorndal and Meylan, 1983). For example, a small but significant proportion of Caretta that were tagged while nesting on Melbourne Bcach (Florida) has been observed nesting again on different beaches (both within the same scason and in diffecent scasons). The largest recorded nest shifl was a distance of $550 \mathrm{~km}$, but a majority were around $100 \mathrm{~km}$. Less information is available for Mediterranean marine turtles. Females tagged previously at Zakynthos and at Dalyan have been recorded nesting there in later years, and elsewhere on only one occasion (when a female tagged on Zakynthos was observed on Cephalonia); however, it is important to recognise the possibility that the Caretta population nesting in southern Turkey, for example, may be to some extent shared between adjacent beaches rather than being based rigidly at separate sites.

Although nesting turtles, evidently Caretta more than Chelonia, may have some capacity to move nest $\mathrm{site}$ in response to disturbance, this appears effectively to be restricted to new sites in close proximity to the former beach. There is some evidence to suggest that this has happened in recent. years at zakynthos, where beaches previously used by nesting turtles are now used only by tourists, and nesting is concentrated on the most isolated and undisturbed beach. Although nest density may increase at one site as it decreases at the most disturbed site nearby, there are fewer and fower such undisturbed sites to move to. Long distance shifts in nest site are probably restricted to isolated pionecring individuals, and there can be little or no chance of any new nesting population developing within the Mediterranean in this manner.

Large scale tourist development is the most widespread, most direct, and most acute threat to marine Lurtlo nest sites in the Mediterranean. Examples of the effects of development are given in many of the country accounts in this report (e.g., 3.4. Cyprus, 3.7. Greece, 3.18. Turkey); the remainder of this section outlines in general terms the adverse effects of beach development.

Many factors arising from human use and modicication of beach habitats, frequently associated with building developments, have been shown to affect adult female turtles and hatchlings during their time on and near the nesting beach, or are strongly suspected to do so. Witham $(1982,1985)$ has reviewed briefly some of these factors, which include artificial lighting, constcuction 
of jetties, breakwaters and erosion-control structures, sand extraction, vehicular and foot traffic, the accumulation of litter, and eeneral

disturbance due to human presence. Few parts of the coast of countries acound the northern marein of the Mediterranean, and the larger islands, remain unaffected by tourist, residential, industeial or agricultural development.

\subsubsection{Foot t.cafric}

Because the nesting female turtle firmly packs the sand on top of her newly laid nest, it is unlikely that human pedestrian traffic would cause significant physical damage during egg incubation (Witham, 1984). However, during hatching and emergence, a single footfall on the nest area could casily collapse the now loosened sand and crush the hatchlings (Witham, 1984).

\subsubsection{Vehicular/animal traffic}

Although not quantified, most motor vehicles would appear to be capable of causing nest damage at any stage of incubation, either by direct compaction or by excavation of whecl ruts. In addition to potential nest damage, such ruts may trap hatchlings on their way to the sea (Withan, 1984). Large domeslic animals are capable of causing nest damage because of their high weight in relation to low hoof surface area. The use of beach umbrellas can cause damage by direct penctiation of nests and, potentially, by shading nosts resulting in aberrant temperature regimes (the nest temperature is important because sex is determined according to prevalent temperature during a critical phase in early development).

\subsubsection{Boat traffic}

It is generally the case in sea turtles that mature males and females assemble for mating purposes at the start of the breeding season in waters just of the nest beach. Whilst foraging turtles are vulnerable at any time to physical injury by boats, notably propellor-powered speedboats and cruisers, their aggregation during the mating period renders them particularly liable to injury.

\subsubsection{Artificial lighting: effect on hatchlings}

Whilst it is possible that interspecific differences in detail exist, artificial light has been demonstrated to be capable of disorienting newly-emerged hatchlings in all sea turtle species investigated, including Caretta and C. mydas (Mortimer, 1982; Raymond, 1984).

The results of numerous investigations (reviewed by Raymond, 1984) indicate that once sea turtle hatchlings have emerged from tha nest (typically at night) their orientation toward the sea depends largely on a visual response to relative light intensities, primarily on the horizon. On undisturbed nestine beaches, movement toward the brightest horizon will generally be equivalent to movenent toward the sea; where artificial lightine affects the beach, hatchlings are frequently disorienled and spend long periods of time wandering the beach or moving landward toward the light source. These hatchlings are then more exposed to predation pressure (e.g. by beach crabs) and are liable to die from desiccation during the following day. These phenomena have been widely and consistently reported, at many nesting beaches around the world, where the beach is affected by artificial light (Raymond, 1984). Although few quanlitative data are available, it is possible that a significant proportion of the annual hatchling production can be lost in this 
fashion. In a recent study on a major florida nest beach, disorientation of hatchlings was found to decrease following resteictions placed on the use of beachfront lights (Ehrhart and Witherington, 1987).

\subsubsection{Artifical lighting: effect on nesting females}

It appears that the sea-finding ability of females, haying nested, depends on the same process as in emergent hatchlings. As with hatchlings, individual turtles can be induced to follow a light source, such as a torch, and similarly, where the landward side of the beach is subject to artificial lighting (either directly, or a general glow from distant grouped town lights), females are often found to have moved inland away from the sea rather than towards it, and are liable to become trapped and die from heat and exhaustion.

Disorientation of nesting females does not appear to be as widespread a phenomenon as the disorientation of halchlings. To a large extent, this is likely to be because nesting females, at least of some species and at some sites, tend not to emerge on beaches subject to artificial lighting (Mortimer, 1982). On Melbourne Beach, Florida, preferred C. mydas nesting sites were negatively correlated with the presence of beachfronl lighting, but interference with nesting was eliminated when the offending lights were dinmed (Ehrhart and witherington, 1987).

Whilst moving lights will deter females of all marine turtles from nesting, there are indications that stationary artificial light in some cases has 1 ittle demonstrable effect on nesting of Loggerhead Caretta caretta (Mortiner, 1982). For example Mann (1977, cited by witham, 1982) commented that many Caretta females nesting in Florida continued to do so on highly developed beaches, with bright background lighting, tall buildings, and human activity, even though some of the more natural beaches available nearby were only lighlly nested. This contrasts with the overall situation in south-east USA (see below). Witham (1982) suggests that in some instances it is 1 ikely to be human activity, which would involve noise and moving lights, rather than lighting alone, that is responsible for reduced nesting activily.

Overall, it appears that on otherwise equivalent beaches, nesting will become concentrated on sectors least affected by phenomena associated with development. This is certainly the case on 7akynthos, where most nesting now occurs on sekania, the most isolated beach, and little occurs at Laganas, previously heavily used (Margaritoulis, 1982; Sutherland, 1984). Decline in turtlo nesting on Hutchinson Island (Florida) is attributed to increased urbanisation, involving increased artificial light levels and human activity, among other factors (Worth and Smith, 1976). Similarly, in South Carolina, Dean and Talbert (1975) recorded lowest Caretta nesting activily on beaches subject to development, with no controls on lighting, and reported that nesting was increasing on undisturbed beaches. Shabica (1982) cites several cases in south-east USA where turtle nesting has increased on beaches within protected areas, as females have apparentiy shifted their nesting activity in response to development pressure on beaches previously used. 


\subsection{Interchange between the Mediterranean and Atlantic}

Only two documented examples of entry into the Mediterranean from the atlantic have been located: (1) a Lepidochelys kempi - a species that breeds only in the Gulf of Mexico, and has been widely recorded at sea in the north west and north-east Atlantic - has been recorded in Maltese waters (Broneersma and Carr, 1983); (2) a head started Caretta caretta released of $\mathrm{f}$ Padre Island, rexas, was recaptured four years later off south-east Italy.

However, circumstantial evidence, and casual observations of turtles at sea near the straits of Gibraltar, suggest that turtles may enter the Mediterranean reeularly, and possibly in substantial numbers. For example, the Leatherback Dermochelys coriacea has been widely and not infeequently recorded in the Meditercanean, and small groups have been seen in the vicinity of the straits of Gibraltar: no confirmed nesting sites are known within the basin and it may thus be assumed that most or all Leatherbacks in the Mediterranean are inmigrants, probably from Atlantic nesting populations.

Discussing the long distance movements of juvenile turtles, Carr (1987) believed it reasonable to discount the suggestion that the juvenile sea turtles seen in the east Atlantic, particularly the islands, are derived from the Mediterranean. The known nesting colonies in the Medilerranean seem tuo small to supply such numbers, and westward movement would presumably be hindered by the strong surface current that moves eastward from the Atlantic to the Mediterranean over the Gibraltar sill. The rate of flow here has been estimated at almost a million cubic metres per second, and the contrary westward flow takes place at a depth of 80-100 m (kistrada et al., 1985). Carr sugrested that "instead of contributing turtles to the Atlantic population, the Mediterranean more probably receives strays from the transatiantic migrations of American turtles"; he further suggested that some of the $20-40 \mathrm{~cm}$ size class Caretta found around the Azores might drift out of tho main Azores-Canary Current and into the branch that flows eastward through the Straits of Gibraltar. The mainly immature Caretta that occur around the Balearics are consistently a little larger than those present around the Azores (data of Mayol and Castello Mas, plotted by Carr, 1987).

The progressively larger size distributions of turtles from five sample populations: (1) advanced hatchlings and juveniles from waters off south oast USA, (2) the Azores, (3) the Balearics, (4) sub-adults from south-cast USA, and (5) mature nesting turtles from filorida beaches, may correspond in part to successive points on a North Atlantic Caretta developmental and migratory pathway, driven and stabilised by large scale ocean currents (Carr, 1986. 1987).

It is uncertain whether the Balearic Caretta, and turtles of Atlantic origin elsewhere in the Medilerranean basin, are permanently diverted from this sugerated pathway, or are able to leave the basin and return eventually to the west Atlanlic breeding grounds. According to Brongersma (1982:414), marine turtles are known to move through the straits of Gibraltar in both directions, but whilst there is some direct evidence (cited above) that At lanlic turles do enter the Mediterranean, there appears to be no similar evidence that lurtles move in the opposite direction, from the Medileceancan to the Atlantic. 
It is possible that the Gibraltar straits may act as a filter that results in a net gain to the turlle population of the Mediterranean.

The extent to which exchange does occur is a vital piece of information: the massive incidental catch problem in the Mediterranean would be less severe for the small nesting populations within the basin if the pressure was borne by American populations in addition. Argano (1979) concluded that the turtles being affected by incidental catch in the western Mediterranean are mainly derived from populations nesting in the eastern Mediterranean, but partly rrum Atlantic populations. The relative contribution of these two source areas remains to be assessed. This would be possible if peesent studies of genetic (mtDNA) relationship between Caretta samples from nest siles in Nurth America and Greece (Meylan, pers. conm.) were extended to include samples from imature turtles caught at sea around the Balearic $1 \mathrm{slands.}$

It might even be speculated that some turtles of Atlantic oriein may attain maturity within the Mediterranean and subsequently breed there. This would certainly not be expected if, as frequentily proposed, mature turtles consistently return to their natal beach for breeding, but il would be possible if newly maturing females find their first nesting beach by joining cxisting nesting aggregations. This hypothesis could be tested if means could be found reliably to tag sub adult Atlantic Caretta, perhaps those encountered at sea around the east Atlantic islands.

The weslern Mediterranean aggregations of Caretta may be correlated with the presence of a permanenl "front" (a convergence of currents where downwelling results in the accumulation of food items and other flotsam) that extends across the Balearics from Almeria (Spain) to Oran (Algeria) (Carr, 1987).

\subsection{Turtle movements within the Mediterranean}

Whilst long distance migration of nesting females between reeding grounds and nesting beaches is a well established phenomenon in many marine turtle populations, particularly of Chelonia mydas, the distribution and movenents of males and of different age groups are scarcely known at all. information on the dispersal and migratory movements of Mediterranean marine turtles is very sparse and generally inconclusive.

Most data relate to the Caretta population that nests on Zakynthos (Grecce), which has beon the subject. of one of the very few tagging programmes in the Mediterrancan, and which has produced the largest sample of tagged turtles in the basin. Caretta nesting in Greece have been shown by recaptures of tageed females (Margaritoulis, 1988) to disperse over a very wide area of the central Mediterranean, extending west to Sardinia, east to western Turkey, north to the Adriatic and Aegean, and south to Tunisia and Libya.

Logeerheads captured at sea of $[$ south cast italy, then tapged and released, have been recaptured in the same general area as the Zakynthos population recaptures (although records to date have not extended as far west or east as Sardinia and Turkey, respectively) (Argano and Cocco, 1988). Although some proportion of the sample tageed in Italian waters may have originated on Greck nesting beaches, which are relatively close, with only two exceptions the origin of all the turtles in the Italian sample is unknown. The exceptions are one turtle tageed at Zakynthos later recaptured in south east italy, and, most notably, the Caretta that was head-started in Texas and recaptured four years later off south-east Italy (Manzella et al., 1988). 
Laurent ot al. (in press, 1989) report the capture in the Gulf of Gabes (Tunisia) of a chelonia nudas beacine a tag applied in Cyprus. This appears to be the only documented long distance movement of a chelonia within the basin. There is indirect evidence for seasonal migration of turtles. including Chelonia, along the tevant coast of the eastern Mediterranean (sec section 3.8 .5$.$) .$

Accordine to Geldiay (1984), turtle populations (both Cacetta and Chelonia) nesting on the lurkish coast are resident, and do not leave Turkish waters. Whilst inmatures, sub-adults and adults of $C$. mydas are present in the Gulf of Mersin and Gulf of lskenderun through much of the year, and presumably orieinate from Turkish nest beaches, Caretta appears lo be less frequently recorded and, according to Baran and Kasparek (1989b), most individuals disperse to distant waters.

To date, no turtle Lagged on a Mediterranean nesting beach has boen recorded anong the large number of turtles captured accidentally by fishermen around the Balearic lslands. A large proportion of these turtles are sub-adult and so could not have been tagged on a nest beach, but (as discussed further above), there is a distinct possibility that a significant number of the Balearic Caretta are of Atlantic origin.

As noted by Laurent (in press), most Caretta secn at sea in the Mediterranean are singles, or in very small groups. Aggregations of turtles (cited in the country accounts above), including Caretta, have been reported much too infrequently to allow clear inferences on group movement to be drawn. The one posible exception concerns Caretta in the western Mediterranean and the Straits of Gibraltar, where movement between the Atlantic and Medilerranean is suggested (see above).

The pattern of movements indicated by available evidence is not simple and, unlike cerlain other sea turtle populations around the world, it is not the case that one nesting population migrates regularly only between the nesting beach and a discrete coraging area. An enormous zone of the central Mediterranean appears to conslilute the non-nesting range of the Zakynthos Caretta population, doubtless for Caretta from other Mediterranean nest. beaches, and probably even for some immature and sub-adult turtles from Atlantic nesting beaches. On the other hand, there is some evidence that some components of the nesting Chelonia population in Turkey are resident in Turkish waters. The distribution of different age groups, different sexes, and different nesting populations are all almost entirely unknown.

Within-population movements recently demonstrated by the results of a long-term study of Logeerheads in the west Atlantic (Henwood, 1987) may be more generally applicable, and may be a feature or Medilerranean Loggerheads. Henwood produced good evidence that the mature females which nest in the vicinity of Cape Canaveral (Florida) are short-term visitors that migrate into the area at two or three year intervals, and reside elsewhere in non-nesting years. Mature males do not migrate with the females, but appear to remain in the vicinity of the nest beaches throughout the year. Sub-adult turtles nove opportunistically along the Atlantire coast, moving northward in sunmer and south in winter, where a resident sub adult population overwinters in the Canaveral area (large numbers have been dredged up from the sea bottom, encased in mud).

\subsection{Wintering and foraging areas}

A siznificant number of Caretta in an apparent state of torpor have been taken in fishing nets over arcas with a mud substrate in the central and north 
Adrialic, and the suggestion has been made that this is an important over-wintering or "hibernation" site. It is important to gather nore information on the phenomenon of winter dormancy in Medilerranean sea turt.les because dormant turtles are especially vulnerable to incidental catch in trawl nests.

Among Loggerheads in North American waters, the observed responses to decreasing water temperatures vary within a population or species; some individuals migrate, some hibernate (Ogren and McVea, 1982). In the Mediterranean, it may be the case that some Caretta in the centeal and north Adriatic, for example, are forced by decreasing water lemperature to remain there, while others are able to muve southward toward reeding grounds along the coast of North Africa.

A large number of Caretta, including some $40 \%$ of the reporled recaptures of turtles tagged on Greek nest beaches, occur regularly in the Gulf of Gabès, Tunisia. Most recaptures of the turtles tagged in Greece have occurred during the winter months. Although the high number of tag returns must to some extent be a reflection of the intensity of the turtle fishery in Tunisian waters, it seems certain that the Gulf of Gabès is a major foraging and wintering area for Mediterranean Caretta (see section 3.17.3. for further details).

It appears that some marine areas occupied by turtles during the winlor will also be sites of active foraging (e.g. the Gulf of Gabès), whereas other areas (such as the central-north Adriatic) may be sites where turtles overwinter in a state of torpor. The extent of activity during the winter months is probably directly correlated with sea temperatures and the availability of food items. Loggerheads at sea in the norLh-west Mediterranean (Corsica) leave the area rather abruptly at the end of summer, possibly for warmer waters to the south and east. This may be the prevailing trend Cor Mediterranean Loggerheads.

Green Turtles of various age classes, and Caretta less frequently, are present. in winter in the Gulf of Tarsus (Mersin) and Gulf of Iskenderun (see discussion in section 3.18.5. above, for further details). This region was highlighted by Gruvel (1931) as a major centre of turtle abundance, and this appears to be confirmed by more recent observations (see Turkey account. 3.19.5.). There are suggestions that, historically, regular movements were made northward along the Levant coast loward nesting grounds in Turkey. Good numbers of Chelonia reportedly occurred in previous years alone nore westerly sectors of the Mediterrancan coast of Turkey, where beds of sea grass, on which the speries feeds, are present.

Overa11, little detailed information is available on the distribution of turties in Mediterranean waters. Virtually all records are made incidental to other human activity, generally by fishermen. Observations are thus limiled to present fishing grounds, and to waters of a particular depth and within a certain distance from land. Loggerheads appear to occur in good numbers around the Balearics, southern 1 taly. Malta and Tunisia, and perhaps in lesser numbers or more seasonally around corsica and sardinia. To some extent this peobably reflects the distribution of fishing activity as much as turtle distribution, but perhaps turtles and fishermen pursue their rood resources in similar waters for similar reasons. With the notable exception of the Gulf of Gabès off southern Tunisia, and the Gulf of Tarsus and Gulf of lskenderun off south-east Turkey, it is difficult on present information to make any bul the most generalised statement about prefercod foraging grounds. 


\subsection{Turtles in the Eastern Mediterranean}

Gruvel (1931) regarded the norlh-east corner of the Mediterranean, betwcon the cilician coast. of Turkey and the coast of syria, including the Guif of lskenderun, as a centre of sea turtle abundance. The Logeerhead was reportedly found in the Gulf of Iskenderun and the Gulf of Tarsus (south of Mersin) in particular, but also, less conmonly, along the Levant coast. One sweep of a trawl in the Gulf of lskenderun would yield as many as 60 caretta which would be exported to kingland, via Cyprus and Alexandria (Gruvel, 1931).

It is noteworthy that, according to earlier authorities such as Lortot (1883, 1887) and Gruvel (1931), the Loggerhead Caretta caretta ( = Thalassochelys caouana or $T$. caretta) was by $r$ a the most abundant sea turtle in the eastern Mediterranean, and was the species most utilised in the international turtle trade of the 1920s; Chelonia and Dermochelys were relatively rare. On the other hand, Hornell (1935) and sella (1982) reported that Chelonia mydas was virtually the sole target species of fisheries operating off northern lsrael in the 1920 s and 1930s, and in the Gulf of Tarsus-Gulf of Iskenderun region of Turkey during the $1950 \mathrm{~s}$ and 1960s. Hornell worked in what is now northern lstael, while Gruvel worked along the coast of Syria and what is now Lebanon, and it is conceivable that chelonia was then prevalent in the former area, and Caretta in the latter. The possibility of misidenlification cannot be entirely ruled out. Hornell was certainly familiar with Chelonia from his risheries experience elsewhere. The lengths cited by Lortet $(1.5 .2 \mathrm{~m})$ and Gruvel (1.1-1.2 m) for their turtles seem excessive, but would be more similar to Chelonia than to Caretta; the average curved carapace length of Caretta nesting now in the Mediterranean is close to $0.8 \mathrm{~m}$ (it is possible that the earlier measurements included the carapace plus head). If the various authors were correct in their species identifications, it must be concluded that there has been a radical reversal in the relative abundance of each species.

\subsection{Incidental Catch}

A very large number of turtles, mainly caretta, are caught in rishing gear in the Mediterranean, usually, but not exclusively, incidental to other fishine activities. The number of turtles caught is not equal to the number of turtles killed as a result of incidental catch; long-lines are typically hauled in at frequent intervals, and hooked turtles are not necossarily drowned (turtles are often released, and turties have been caught with old hooks in their mouth, indicating that individual turtles certainly can get hooked more than once). Turtles caught in nets, which (particulacly if set for spiny lobsler) tend to remain in place for much loneer periods, are more orlen drowned. Available data do not permil a firm estimate of aclual turlle mortality to be made.

Roberto Argano (1979) conducted a preliminary enquiry among Cishermen in a total of 50 ports along the coast of Spain (mainland), Algeria, Tunisia and Italy (sec Table 25). It was concluded that a minimum of 3000 turles are killed annually in the Wostern Medilerrancan, mostly incidental to other fishing activities, particular'y when longlining for swordrish and, for example, trawling in the sicilian Channel. Argano (1979) stated that only a few of the turtles caught are kiljed, which must imply that the total number of turtles caugh is greatly in excess of 5000. Turtles used for stureing, or for carapace preparalion (both for tourist souvenirs or curios), are typically killed imnedialely; those used ror food (south ltaly, Spain, Tunisia) are orten kept swinming in the harbour (as seen at Capraia and the ponza Is.) or on board ( $S f a x$ ) until required. Argano considered that sale of turtle meat is only occasional in most areas, and that the economic significance of turtlo meat was negligible. 
Table 25. Provisional estimates of the number of turtles killed by fishing operations in the Western Mediterranean, based on interviews conducted in 1978 by $R$. Argano (Argano, 1979). Most turtles are assumed to be Caretta, and most are killed incidental to other fishing activity.

$\begin{aligned} & \text { Number of turtles killed annually } \\ & 10-100 \\ & 100-500\end{aligned} \frac{500-1000}{100} \quad>1000$

Algeria: total $<100$

Italy: total $350 \rightarrow 3000$

$\begin{array}{lll}\text { Gallipoli } & \text { Eolian Is. } & \text { Mazara } \\ \text { Palermo } & \text { Trapani \& } & \text { (Sicily) } \\ \text { P. Emedocle } & \text { Marsala } & \\ \text { Licata } & \text { Sciacca } & \\ \text { Lampedusa } & & \end{array}$

Spain: total c. $650-3150$

$\begin{array}{ll}\text { Alicante } & \text { Castellon } \\ \text { Almeria } & \text { Altea } \\ \text { Adra } & \text { Cartagena } \\ \text { Motril } & \text { Aguilas } \\ \text { Malaga } & \text { Estepona } \\ \text { Tarifa } & \text { Algeciras }\end{array}$

Tunisia: total c. $1000->3000$

Sousse.

Biserte

Sfax Tunis

More recent surveys by different investigators have allowed firmer estimates of the total turtle catch to be made, although it is not always clear to what extent the total catch is equivalent to total mortality. Most notably, two studies around the Balearic Islands have sugfested that between 16000 and 20000 Caretta are caught annually by long-line fishermen; many of these are released but some may subsequently die. Some turtles appear to be caught more than once. Also, the total harvest in Tunisian waters now scems much larger than Argano suggested; turtles are sold in coastal markets and are used extensively for food (N.B. the harvest was reportedly largely eliminated during the 1989-1990 season).

By combining the various estimates available for different areas within the Mediterranean (summarised in Table 26), it can be estimated that up to 50000 turtle captures might occur annually. Most are Caretta, including immatures, sub-adults and adults. Most are caught by accident; an unknown but large proportion are thought to survive capture. Judging by preliminary estimates available from Malta (Gramentz, in litt., 1988), which suggest that $15-50 \%$ of turtles caught on long-lines may survive, it might be speculated that the total mortality is likely to be about 12000 turtles per annum (calculated as the total Tunisian catch, all of which is harvested, plus $15 \%$ of the remainder of the total Mediterrancan. catch).

It is thus theoretically possible that incidental catch is removine from the total regional population (of immatures, sub-adults and adults) a number far 
Table 26. Summary of current annual turtle catch in the Mediterranean (sec countey accounts for data sources). Key: in second column,

$A=$ accidental catch, $T=$ targel species; in third column, LL = long-line, $N=$ net, in fourth column, $C_{.} c_{0}=$ Caretta, C.m. = Chelonia.

Area
Accidental or Target species
Fishing species method

LL, $N$

c.c.

500

\begin{tabular}{|c|c|c|c|c|}
\hline Algeria & A & LL, N & c.c. & 500 \\
\hline Cursica & A & $N(L L)$ & C.c. & significant numbers \\
\hline Cyprus & A & N & C.c., C.m. & low ? \\
\hline Egypt & $\mathrm{T}$ & $?$ & $?$ & probably high \\
\hline Greece & A & LL, $\mathbf{N}$ & c.c. & significant numbers \\
\hline Isracl & A & $\mathbf{N}$ & ? & very low \\
\hline $\begin{array}{l}\text { Italy } \\
\text { mainland }\end{array}$ & A & LL & c.c. & $\begin{array}{l}250-1000^{1} \\
16000^{2}\end{array}$ \\
\hline $\begin{array}{l}\text { Lampedusa } \\
\text { Sardinia } \\
\text { sicily }\end{array}$ & $\begin{array}{lll}A & & \\
A, & T & ? \\
A, & T\end{array}$ & $\begin{array}{l}\text { LL } \\
? \\
\text { LL, N }\end{array}$ & $\frac{\frac{C . c .}{\text { C.c. }}}{\text { C.c. }}$ & $\begin{array}{c}150-300^{3} \\
? \\
>600^{4} \\
>5000^{5} \\
>1000^{6}\end{array}$ \\
\hline Ma1ta & $A, T$ & $\begin{array}{l}\text { LL, N } \\
\text { (etc.) }\end{array}$ & C.c. & $\begin{array}{l}1000-3000 \\
500-600^{7}\end{array}$ \\
\hline Morocco & A & LL & C.c. & $>3000^{8}$ \\
\hline Spain & & & & \\
\hline mainland & A & LL, $\mathbf{N}$ & C.c. & $>1000$ \\
\hline Balearic Is. & A & LL & C.c. & 16000 \\
\hline Tunisia & A & $\mathbf{N}$ & C.c. & $4000-5500^{9}$ \\
\hline Turkey & A & LL, N & c.c., c.m. & $?$ \\
\hline
\end{tabular}

A, T ?

A, T
Number of captures per year
$16000^{2}$

$150-300^{3}$

?

$>600^{4}$

$>5000^{5}$

$>1000^{6}$

$1000-3000$

$>3000^{8}$ approximate total annual captures: estimated total mortality 10 :)

Notes: 1 Gulf of Taranto only; 2 Ionian coast of Calabria only, total catch not total mortality; 3 mortality estimate; 4 Isole Eolie (Lipari) only; 5 total catch in Sicilian waters; 6 mortality estimate for all sicilian waters: 7 mortality estimate; 8 total catch, not total mortality; 9 turtles taken when caught (N.B. turtle harvest was reporledly largely eliminated during winter 1989. 1990 - sec country account); 10 calculated as total Tunisian harvest, plus $15 \%$ of remaining estimated total catch. 
greater than the estimated annual nesting contingent and has probably been doing so for many years. These elementary calculations, if the catch and nesting data are reasonably complete and reliable, indicate that either: (1) the Meditercanean nesting population of Caretta will suffer a rapid collapse in numbers once the survivors of the present nesting contingent reach the end of their reproductive activity, or (2) the population of sub-adult and adult Caretta in the Mediterranean is continually being replenished by turtles entering the basin (probably mainly through the straits of Gibraltar and derived mainly from North American nesting beaches).

\subsection{Turtle exploitation}

The history of turtle exploitation in the Mediterranean is poorly known. Literature accounts and direct evidence for large scale commercial harvest of turtles for food date mainly from the present century, when many thousands of turtles were harvested in the eastern Mediterranean (see Table 27). Available information suggests that turtles, certainly along the Levant coast, were harvested mainly at sea, although exploitation of the Turkish nesting Chelonia population has included collection of turtles from the nesting beaches (the latter form of exploitation has a more rapid effect on nesting numbers).

There is some uncertainty over the species involved in the turtle trade in the early twentieth century. As noted in section 5.4., above, early authorities such as Lortet (1883, 1887) and Gruvel (1931) reporled that the Loggerhead Caretta caretta (= Thalassochelys caouana or $\mathrm{T}$. caretta) was by far the most abundant sea turtle in the eastern Mediterranean. Gruvel (1931) stated that Caretta was the species most utilised in the east Mediterranean turtle trade of the 1920s, and Flower (1933) remarked upon the widespread use in the Mediterranean of Caretta as the basis of "turtle soup". According to Gruvel (1931), one sweep of a trawl in the Gulf of 1 skenderun would yield some 60 Caretta which would be exported to England, via Cyprus and Alexandria.

In contrast, Hornell (1935) and sella (1982) reported that Chelonia mydas was virtually the sole target species of fisheries operating off what is now northern Israel in the 1920s and 1930s, and in the Gulf of Iskenderun-Gulf of Tarsus region of Turkey during the 1950 s and 1960s. Hornell worked in Palestine, while Gruvel worked along the coast of syria and what is now Lebanon, and it is conceivable that Chelonia was then prevalent in the former area, and Caretta in the latter. However, the possibility of misidentification cannot be ruled out.

Gruvel (1931) reporled that there was a marine holding pen for turtles at Fort Kait Bey, near Alexandria (ligypt), with a depth of around one metre, and a fence of iron bars allowing water to flow through but preventing the turtles' escape. The turtles were brought from Cyprus, Iskenderun, Beirut, and other ports, and were kept until a transport ship was leaving for London, where there existed a large market for turtles. Hornell (1935) reported that turtles fished in Palestinian waters were exported to Egypt in the 1920s, most. presumably to be re-exported to London; the turlle rishery reported by sella (1982), based on information from an aged fisherman operating out of Acre (Israel) was presumably serving this same market. Turkey appears to have been the major post-World War II source of Mediterranean C. mydas in trade; the turtles were processed at Iskenderun and the products exported to Europe.

Large scale commercial harvest and trade in turtles has declined in the Medilerranean during the past two decades, due probably to a combination of factors, includine: the spread of peotective legislation, the implementation 
of restrictions in trade in wildife (for example, arising from the convention on International Trade in Fndangored species of Wild Fauna and Flora), the decline in consumption of luxury food items such as turtle soup, and a decline in available turtle stocks.

On current infornation, which is not complete, harvesting of turtles is largely restricted to Tunisia (where around 5000 Caretta are taken annually for food); to Malta, sicily and adjacent islands, and Sardinia (where turtles are much less widely consumed and many fewer turtles are harvested); and to Egypt (where the size of the turtle catch is unknown). The Caretta taken in Tunisia are reportedly caught accidentally while trawling for fishes. There is no confirmed intentional harvest of Chelonia (although the species may well be caught in Egypt), and the peesent relatively small populations could certainly not withstand any large-scale exploitation.

Although exploitation is not a widespread threat to turtles in the Mediterranean, the reported harvest of Caretta in Tunisian waters is a cause for very serious concern. A number of turtles tagged in thaly and Grecce have been recaptured in Tunisia, and given that tag returns always constitute a very small proportion of the total tagged, it is reasonable to assume that. this fishery is causing heavy mortality anong central Medilerranean Caretta populations. When combined with other adverse facturs affecting these populations, particularly the severe disturbance to nest beaches on Zakynthos, such artificial mortality is unlikely to be supportable in the long term.

It is necessary to reduce turtle harvest to a level compatible with the long-term survival of turtle populations; given the present poor conservation status of Medilerranean turtles, a near zero harvest is desirable. However, as Lescure (pers. comm.) has stressed, the turtle fishery in Tunisia is curcently of great socio-cconomic importance; turtle meat is cheaper than rish and is an affordable and accessible source of nutrients for coastal communities.

Table 27. Summary of historical commercial turtle harvest in the Mediterranean at known major sites. Data from Sella (1982). Catch figures are minimum estimates. For example, the Israel data refer to one fishing organisation only; others are known to have been operating in the period covered, but no information is available. Turtles are known to have been harvested in other countrics, but no details are available.

\begin{tabular}{|c|c|c|c|c|}
\hline Area & Species & Period & $\begin{array}{l}\text { Numbers } \\
\text { per year }\end{array}$ & $\begin{array}{l}\text { Total } \\
\text { catch }\end{array}$ \\
\hline lsracl & $\frac{\text { C. mydas }}{\text { (Caretta?) }}$ & $\begin{array}{l}\text { 1920s } \\
\text { early } 1930 \mathrm{~s}\end{array}$ & c. 2000 & $>30000$ \\
\hline Turkey & C. mydas & $\begin{array}{l}\text { early 1950s } \\
-1960 \mathrm{~s}\end{array}$ & c. 2000 & $>30 \quad 000$ \\
\hline
\end{tabular}

\subsection{Pollution}

The extent to which water-borne pollutants are affecting marine turtics at sea, and the pollutants concerned, are poorly known, and most investigations are of very recenl dale. Twenty out of 99 Caretta examined in Maltese waters 
were found to be contaminated, 11 of these with crude oil affecting the mouth cavity and gut, and a few with plastic or metal objects (Gramentz, 1988). $0 i 1$ pollution, although poorly quantified as yet, is likely to be a near universal problem in the Medilerranean basin.

Some of the litter dumped from ships certainly ends up on beaches used by turtles, notably on Cyprus and eastern Turkey, but its efrect on nesting females and emerging hatchlings is not clear. plastic waste at sea is likely to pose an additional problem; Caretta and Dermochelys have boen recurded to ingest plastic litter (which may deift in water in a similar manner to the pelagic coelenterates which figure largely in the diet of both species) (Van Nierop and Den Harlog, 1984). This has been implicated in the death of sume specimens.

Heavy metals and agrochemical residues are suspected to be affecting walers inhabiled by turtles in southern Italy and south-east Turkey (notably, the main Green Turtle nesting area in the Medilerrancan). These areas in particular, and the phenomenon in eneral, require further investigation; pollution, while less obviously damaging than incidental catch or beach modification, is potentialiy no less important as a threat to turtle populalions. 


\subsection{General remarks}

This section covers four species, only one of which, the Leatherback Dermochelys coriacea, is recorded reqularly (albeit infrequently) in the Meditereanean. It is possible that a few Dermochelys clutches might be laid on Mediterianean beaches from time to time but, on the assumption that no regular nesting occurs, the significant nunber of Leatherbacks recorded in the basin must represent immigrants from Atlantic nesting colonies.

Two further species, the Hawksbill Eretmochelys imbricata and Kemp's Ridley Lepidochelys kempi, are known to occur in the Medilerranean, but are presumed to be accidental rare inmigrants only. Documented records of these species are represented by three, and one, museum specimens respectively. A fourth species, the olive Ridley Lepidochelys olivacea, might perhaps occur very rarely, bul no documented records of specimens originating from the Mediterranean exist.

\subsection{Leatherbeck Dermochelys corlacee}

A recent review (Lescure et al.., in press) concludes that, while Dermochelys has been known since at least the late eighteenth century as a member of the marine fauna of the Mediterranean, nesting has always been extremely rare.

A small number of female Leatherbacks have been captured in the Mediterranean and dissected; well developed ovules have been seen in those taken in spring, and reduced ovaries in those taken in autumn. As lescure et al. report, this has led to speculation that nesting might occur within the basin. Although emergence crawls, or apparent nesting, have been recorded in Israel, Italy and Malta, no adequately documented inslance of Dermochelys nesting in the Mediterrancan is known.

Delaugere (1988) cites a reference in an 1853 publication to Leatherback nesting on the Barbary Coast of Morocco, but notes that this cannot now be evaluated. According to Sella (1982), while Dermochelys is rather rare in Israel, evidence exists of possible nestings; huwever, the only data provided refer to tracks found in June 1963 on a beach at palmachim, south of Tel-Aviv. The tracks were attributed to this species by virtue of their width $(1.10 \mathrm{~m})$, but this is inconclusive, and no nests were found. Bruno (1978) reported apparent nesting by Dermochelys, following discovery of two young individuals on a beach at Macconi (Gela Province) on the south coast of sicily in september 1961, and of eges in the same area in June 1967; other workers have expressed some reservations about the sparse and conflicting evidence presented, and are not convinced that nesting occurred (Argano, 1979; Lescure et al., in press). More recently, Gramentz (in litt., 26 July 1988) has reported a Leatherback emergence on Lampedusa (1taly) which did not result in successful nesting.

The best evidence that successful nesting may have occurred in the Mediterranean is provided by the occasional capture of small and very small specimens. Delaugerre (1988) considers that a very young animal (carapace length $73 \mathrm{~mm}$ ) preserved since 1835 in the Muséum National d'Histoire Naturelle in Paris (MNHNP 632), and said to originate from the Mediterranean, constitutes the sole evidence that Dermochelys has nested in the basin; this cannot be regarded as conclusive, given the frequent locality errors 
associated with museum specimens of such age. A second specimen, now in the Florence Muscum (MZU6 12142), was taken off Messina in southern sicily in April 1896, and is around 66 rum in carapace length. Both these specimens are around $10 \mathrm{~cm}$ larger than hatchlings (from the French Guiana population), and may well be under one year in age. At least two additional young Dermochelys have reportedly been taken off sicily (Bruno, 1978), but further details, or specimens, are not available.

In summary, no female Dermochelys has ever been observed on a nesting emergence, or actually nestine, on any beach in the Mediterranean; no adequate documentation of any supposed emergence or nest has ever been produced.

Although it seems guite possible, even probable, that one or two nests a year may be laid on Mediterranean shores, it is unlikely that any regularly used nesting site exists, and there is no evidence to suggest that Dermochelys ever nested in the Mediterranean in the past in more signiricant numbers.

The Leatherback has quite frequently been reported at sea in the Mediterranean, mainly in the centre and west, although records (summarised by Delaugerre, 1988) exist for almost all countries fringing the Medilerranean, with the apparent exception of Albania and Morocco. Generally, this is a largely pelagic species which inhabits open waters.

Most records are of single animals, but small groups have been observed in the vicinity of the straits of Gibraltar, where 24 individuals (in groups of 2-11) have been reported in less than four years (Delatigerre, 1988). Fernandez and Moreno (1984) report stranding of 11 dead Dermochelys on beaches in Ceuta (a Spanish enclave on the Moroccan coast, on the south side of the straits) in November-December 1980, and one each in July 1982 and August 1983. The Gibraltar straits area has the highest density of Leatherback records within the basin, probably due largely to the fact that individuals or groups moving through the relatively narrow straits are of necessity less widely spread through open waters and so more readily encountered. However, as with all turtles seen at sea, the distribution of reports is as much a record of the distribution of observers as of turtles, and similar aggregations might occur elsewhere in the Mediterranean. According to Delaugerre (1988), these turtles enter the Mediterranean in summer and return to the Atlantic in winter, and doubtless originate from the large nesting colony in French Guiana. No passage through the straits has yet been demonstrated by tageing or other means.

\subsection{Hawksbill Eretmochelys imbricata}

Whilst this species is often said to occur in the Medilerranean, nesting has nover been reported and documented records of the species at sea are almost. non-existent (most literature references to the specics simply repeat earlier references which are not well-substantiated). Threc museum specimens of Eretmochelys, at least one of which is known with reasonable confidence to have been taken in the Medilerranean, appear to constitute the only taneible proof of the species' existence in the basin. 'A young female specimen (recently re discovered in the Musée d'Histoire Naturelle de Marseille) was captuced off Marseilles in 1909 (fretey, 1987; Delaugerre, 1988). Gramentz (in litt.. 26 July 1988) reports that Eretnochelys has also been taken off southern sicily and in Malta, now represented, respectively, by specimens in Palermo and in the Natural History Museum, Mdina, Malta. Gruvel (1931) suggests that any Eretmochelys in the eastern Medilerranean have entered from the Red Sea or Indian Ocean. 
The Hawksbill Fretmochelys imbricata can only be regarded as an accidental and occasional species in the Medilerranean, and such specimens as might exist within the basin presumably enter through the straits of Gibraltar or the suez Canal.

\subsection{Kemp's Ridley Lepidochelys kempi}

This species, like the Hawksbill, can only be regarded as an accidental and occasional species in the Mediterranean. In view of the facts that the single known nesting arca of this highly endangered species lies on the coast of the Gulf of Mexico, and that appreciable numbers have been known to move north and east in North Atlantic currents, it seems certain that whatever individuals might enter the Mediterranean nust do so through the Gibraltar straits. The single documented record of Kemp's Ridley in the Mediterranean concerns a turtle, now in the Natural History Museum at Mdina in Malta, that was originally caught about one mile from the mouth of the Grand Harbour at Valetta in October 1929 (Brongersma and Carr, 1983).

\subsection{Olive Ridley Lepidochelys olivacen}

The only foundation for the suggestion that this species has occurred in the Moditerranean is a turtle reportedly observed by Mertens (1959) in the Aquarium on Rhodes (Grecce) and identiried by him as L. olivacea. As stressed by Brongersma and Carr (1983), it is possible that the turtle had been imported from a source outside the Mediterranean, and there is no documented record of this species in the basin. 


\section{INTERNATIONAL AGREEMENTS}

The Table and discussion below summarises the most important inturnational conventions and protocols which include conservation measures for marine turtles in the Mediterrancan.

It is important to note that such agrecments can al best be only as effective as (a) the national legislation designed to carry out the obligations which a country assumes when ratifying the aqrecnent in question, and (b) the rigour with which such legislation is implemented. National legislation has not always been formulated by the lime of ratification, and its implementation frequently leaves much room for improvement.

Nesting beaches in states: Party to the Bern Convention have been widely modified to the detriment of turtle populations; turtles are harvested in significant numbers in certain counleies where harvest is nominally prohibited by national legislation, and in contravention of clTEs (sce below), which prohibits import from the sea of specimens of species listed in Appendix I; there is no evidence for international efforts to manage species during their migratory phase. It is thus clear that existing international agreements for turtle conservation are being broken by several countries, and certainly are not being adequately utilised to improve the conservation status of marine: turtles in the Mediterranean.

Table 28. Major International Agreements affecting marine turtles in the Mediterranean, and Party states thereto. Key: * = Parly State (in a few instances, a state has signed an agreoment but not yet raticied; these are excluded). Data sources: $a=$ de Klemm (1989), $b=$ WCMC, $c=$ IUCN/UNEP (1988).

$\begin{array}{llllll}\begin{array}{l}\text { AFRICAN } \\ \text { CONVENTION }\end{array} & \text { CITES } & \text { BERN } & \text { BONN } & \text { BARCELONA } & \text { SHA PROTOCOL } \\ 1968 & 19 / 3 & 1979 & 1979 & 1976 & 1982 \\ \text { (a) } & \text { (b) } & \text { (a) } & \text { (a) } & \text { (c) } & \text { (c) }\end{array}$

\begin{tabular}{|c|c|c|c|c|c|c|}
\hline Albania & - & - & - & - & - & - \\
\hline Algeria & * & * & - & - & * & * \\
\hline Cyprus & - & * & * & - & * & * \\
\hline Egypt & * & * & - & * & * & * \\
\hline France & - & * & * & - & * & * \\
\hline Greece & - & - & * & - & * & * \\
\hline Israel & - & * & - & * & * & * \\
\hline Italy & - & * & * & * & $*$ & * \\
\hline Lebanon & - & - & - & - & * & - \\
\hline Libya & & - & - & - & * & - \\
\hline Malta & - & * & - & - & * & $*$ \\
\hline Monaco & - & * & - & - & * & - \\
\hline Morocco & * & * & - & - & * & - \\
\hline Spain & - & * & * & * & * & * \\
\hline Syria & - & - & - & - & * & - \\
\hline Tunisia & $*$ & * & - & - & * & * \\
\hline Turkey & - & - & * & * & * & * \\
\hline Yugoslavia & - & - & - & - & * & * \\
\hline EEC & - & * & * & * & * & * \\
\hline
\end{tabular}


1. The African Convention on the Conservation of Nature and Natural Resources.

All marine turtles are listed in Class A of the Annex to the African Convention, and are thus deemed to be totally protected. Domestic and international trade in specimens of protected species is prohibited except under a pernit.

\section{The Convention on International Trade in Endangered Species of wild Fauna and Flora (CITES).}

All marine turtles are listed in Appendix I of CITES. This includes species threatened with extinction which are or may be affected by trade.

International trade is subject to particularly strict regulation in order not to endanger further their survival, and must only be authorised in exceptional circumstances. Import of specimens from the sea is also prohibited withoul prior permit, the issue of which is subject to particularly strict regulation. In addition, all EEC Member states which are not individually a party to CITES nust apply EF: Regulation $3626 / 82$ which implements clTts within the Comnunity.

\section{The Convention on the Conservation of European Wildlife and Natural Habitats (Bern Convention).}

All marine tuclies in the Mediterranean are listed in Appendix 11 . Article Six requires that each Contracting Party take appropriate and necessary legislative and administrative measures to ensure the special protection of such species. The following are prohibited: deliberate capture, keeping and killing; deliberate damage to or destruction of breeding or resting sites: deliberate destruction or taking of eggs; also disturbance, possession and trade, where contrary to the aims of the Convention. Article 10 requires Parties to cuordinate offorls for protection of migratory species listed in Appendix II (and III) whose range extends into their territory.

\section{The Convention on the Conservation of Migratory Species of Wild Animals (Bonn Convention).}

All marine turtles in the Mediterranean are included, as migratory species in danger of extinction, in Appendix 1. Parties are obliged to provide such species with strict protection. All marine turtles in the Mediterranean are also included in Appendix II. Parties must endeavour to conclude Agreements for the conservation of migratory species whose range enters their territorial limits.

5. The Convention for the Protection of the Mediterranean Sea against Pollution (Barcelona Convention).

The Barcelona Convention obliges contracting Parties to take all appropriate measures to reduce and prevent pollution, and to protect the marine environment. Adopted 18 February 1976; entry into force, 12 February 1978.

\section{Protocol concerning Specially Protected Areas of the Mediterranean.}

The last of three protocols developed within the rramework of the Barcelona Convention. The objective is to protect threatened Meditercanean species, and areas important for their survival. Adopted 2 April 1982, Geneva. The Mediterranean Monk Seal Monachus monachus and the marine turtles are amonest the highest priorities for action during the period 1985-1995 (Genoa declaration, 9.13 september 1985). An Action Plan for the Conservation of the Mediterranean Marine Turtles was prepared in late 1989 (Anon. E, 1989). 


\section{ACKNOWLEDGEMENTS}

Many persons have very kindly spared time and efforl lo assist with the preparation of this report, by providing reprints, unpublished reports or other unpublished informalion, or by responding to questionnaires for by peoviding similar data to the IUCN Conservation Monitoring Centre in the past). Any value to be found in the present report is based on their cooperation, and the author is most sincerely grateful to all who have assisted, including the following: M. Amina, R. Argano, H. Baccar, $S$. Balzan, A.E. Baldacchino, V. van den Berk, L.D. Brongersma, L.F. Cassar, A. Chalabi, A.E. Chircop, M. Cocco, K. Corbetl, M. Delaugerre, A. Demetropoulos, J. Fretey, R. Geldiay, D. Gramentz, M. Hadjichristophorou, R. Jesu, M. Kasparek, H. H. Kouyoumjian, F́. Koyuncuoglu, Z. Kuller, É. Lanf L. Laurent, J. Lescure, D. Margaritoulis, J. Mayol, H. Mendelssohn, C. Mutlu, M.G. di Palma, S. Pisanty, R. Sagarminaga, J. Sultana, A. Taha, L. Venizelos, C. Whitmore.

Written comments on the first version of this report were received fium v. van den Berk, K. Corbett, M. Hadjichristophorou, C. de Klemm, D. Margaritoulis, J. Maigret, J. Robbins, B. Rolle and J. Vournas. Oral comments from several additional sources were received at the second mecting of the Group of Experts on Marine Turtles held at the Council of Europe in October 1989. Relevant comnents on fact and interpretation have been incorporated so far as possible, and the author is indebted to all concerned.

New information has been included in this final version relating primarily to North Africa, Grecce and Turkey. Particular thanks are due to Luc Laurent, for providing copies of reports on his fieldwork in Morocco, Algeria and Tunisia; to Dimitri Margaritoulis and $T$. Arapis for providine reports on work in Greece carried out by the sea Turtle protection Society; and to Miriam Langeveld, for copies of her report (with G. Sariguil) on rieldwork in south-east Turkey. Much new information concerning Turkey has been derived fron the report by 1 . Baran and $M$. Kasparek in which results of the 1988 WWF- FiKC-DHKD beach survey are presented.

Many thanks are extended to veronica Grecnwood for her meticulous editing, and production of camera-ready cupy. 
Anon. a. (1987). "On the spot appraisal" of Caretta caretta conservation at Laganas Bay. Zakynthos, Greece. 25-27 June 1987. Document T-pVS (87) 19 , presented at 1st neeting of Group of Experts on Caretta caretta and Chelonia mydas (Bern Convention), 1--2 September, Strasbourg.

Arion. b. (Corbett, K.). (1987). "On the spol appeaisal" of Caretta caretta conservation at Laganas Bay. Zakynthos, Grecce. 25-27 June 1987. Document T-PVS (87) 18, presented at 1st meeting of Group of Experts on Caretta caretta and Chelonia mydas (Bern Convention), 1-2 September, Strasbourg.

Anon. c. (Corbett, K., Koester, V. [Chairman of the Standing Conmitteo of the Bern Convention] and Ribaut, J.P. [Head of the Environment Conservation and Management Division, Council of Europe] (1989). On the spot appraisal of Caretta caretta turtle conservation at Zakynthos (Greece). DocumenL T-PVS (89) 37.

Anon. d. (Woods, R., kdd.). (1989). 1988, 1989, summary of Annual Reporls. Marine Turtle Project Update. No. 1. Pp. 1-4 (Nowsletler).

Anon. e. (1989). Report of the sixth ordinary Mecting of the Contracting Parties to the Convention for the Protection of the Medilerranean Sea against pollution and its related Protocols. Athens, 3-6 October 1989. UNE'P(OCA)/MED IG. 1/5/ 1 November 1989.

Argano, R. (1979). Preliminary Report on Western Mediterranean Sea Turtles. Unpublished annual report on WWF Project No. 1474.

Argano, R. and Baldari, F. (1983). Status of Western Medilectanean sea Turtles. Rapp. Comm. int. Mer Médit., 28(5): 233-235. (not seen, cited by Lescure in litt.).

Ashkenazi, S. and Sofner, A. (1988). Conservation of the endangered sea turt les Chelonia nydas and Caretta caretta in Israel. Rapports et procès-Verbaux des Réunions. Condensés des travaux présentés lors du XXXI Congrès-Assemblée Plénière Athènes (Gréce) Volume $31(2): 286, V-1116$. C.1.E.S.M., Monaco.

Baran, 1. (1987). Amphibians and Reptiles. In: Anon., Biological Diversity in Turkey. Environmental Problems Foundation of Turkey, Ankara. Pp. 163-175.

Baran, 1. and Kasparek, M. (1988). Study on the nesting sites and population status of the Loggerhead Turtle and the Grecn Turtle in Turkey. Unpublished interim report.

Baran, I. and Kasparek, M. (1989a). Marine Turtles - Turkey. Status survey. 1988 and reconimendations for conservation and management. World wide Fund for Nature.

Baran, I. and Kasparek, M. (1989b). On the whereabouls of immature sea turlies (Caretta caretta and Chelonia nydas) in tho eastern Medilerrancan. Zoology of the Middle East $3: 31-36$.

Bjorndal, K. (Ed.) (1982). Biology and Conservation of Sea Turties, Smithsonian Institution. 583 pp.

Beongersma, L.D. (1982). Marine turlles of the liastern At lantic Ocean. In: Bjorndal, K. (Ed.), Biology and Conservation of Sea Turtles.

Smithsonian Institution. Pp. 407-416.

Brongersma, L.D. and Carr, A.F. (1983). Lepidochelys kempi (Garman) from Malta. Proceedings Koninklijke Nederlandso Akademie van Wetenschappen. Series C, $86(4): 445-454$.

Bruno, S. (1973). Problemi di conservarione nel campo dellerpetologica. Atti 3rd Simp. naz. Conserv. Nat. Bari 2: 117.226.

Bruno, S. (1978). Le tartarughe nei mari italiani e nel Mediterranco. Natura e nontagna, Bologna 25(3): 5-11. 
Caminas, J.A. (1988). Incidental captures of Caretta carette 'L.) with surface lone-lines in the Western Medilerranean. Rapports = proces Verbaux des Réunions. Condensés des travaux yrésentés lors du XxX: Congrès-Assemblée Plénière Athènes (Grèce) Volunc $31(2): 2:$, V-1114. C.I.E.S.M., Monaco.

Capocaccia, L. (1966). Variabilita della popola\%ione meditesanea di Caretta caretta (L.) (Tesludines). Annali del Museo Civic ti Storia Naturale di Genova 76: 1-72.

Carr, A. (1986). Rips, FADS, and little loggerheads. Biosc : ce $36(2): 92-100$.

Carr, A. (1987). New Perspectives on the pelagic stage of SE Turtle Development. Conservation Biology 1(2): 103-121.

Dean, J.M. and Talbert, O.R. $(19 / 5)$. The Loggerhoad turtles : Kiawah Island. Environmental Inventory of Kiawah Island, pp.T-1 := T-19. Colombia, Soulh Carolina, Enviromental Research Centre (c:- $\triangleq$ d by shabica, not seon).

Delaugerre, M. (1988 [1987]). Statut des tortues mariner de a corse (et de la Méditerranée). Vie Milieu 37(3/4): 243-264.

De Metrio, G. and Megalofonou, P. (1988). Mortality of mari:- turtles (Caretta earetta L. and Dermochelys coriacea L.) consequen: : o accidental capture in the Gulf or Taranto. Rapports et Procès-Verbaus tes Réunions. Condensés des travaux présentés lors du XXXI Congrès-Assen te plénière Athènes (Grèce) volume 31(2): 285, V-T115. C.I.E.S.M., Mo: 10.

De Metrio, G., Petrosino, G., Matarrese, A., Tursi, A. and M: anaro, C. (1983). Importance of the fishery activities with drifl $1:-2$ s on the populations of Caretta caretta. (L.) and Dermochelys coriace (L.) (Reptilia, Testudines), in the Gulf of Taranto. Oebalia N.S., 9: 43-:?

Demetropoulos, A. and Hadjichristoghorou, A. (1986). In lit:, 28 June.

Demetropoulos, A. and Hadjichristophorou, A. (1987). Turtles and Turt.le. Conservation in Cyprus (handout for visitors to Lara Turtls 3tation). Department of Hisheries, Nicosia.

Doraniyagala, P.E.P. (1951). Mass movement in some marine $t_{-}-1$ - 1 s and cuttle fish. Spolia Zeylan., Bull. Nat. Mus. Ceylon 26: $1,: 7$.

Despott, G. (1915). The reptiles of the Maltese 1slands. Tt Zoologist 19 (No. 891): 821-827.

Doumergue, M. (1899). Essai sur la faune erpétologique de l'iranie. Bull. soc. géogr. Archéol. Oran. 19-21, 404 pp, 27pl. (not żen, cited by Laurent, 1989a).

Dumont, M. (1973). Le point sur les Tortues marines. Bêtes Ė NaLure 108: 34-36 (not seen, cited by Delaugerre).

Dumont, M. (1974). Les Chéloniens de France. Le courrier de a nature 33: $224-227$.

Khrhart, L.M. and Witherington, B.E. (1987). Human and natu: causes of marine turtle nest and hatchling mortality and their re ionship to hatchling production on an inportant Florida nesting beach. Florida Gane and Fresh Water Fish Commission, Nongame Wildife Programe Technical Report No. 1 .

Estrada, M., Vives, F. and Alcaraz, M. (1985). Life and the zooductivity of the open sea. In: Margalef, M. (Ed.), Western Mediterr Fnvironments Series, Pergamon Press Ltd. Chapter 6, pp. 16 191.

Fernandez, P.G. and Moreno, S.C. (1984). Fmbarrancamiento mesivo de ejemplares de Tortuga Laud (Dermochelys coriacea L.) en las zostas de Ceuta (Espana, Norte de Africa).. Acta Vertebrata, Donana 11(2): $: 2.320$.

F'lower, S.S. (1933). Notes on the recent reptiles and amphit:ans of Egypt, with a list of the species recorded from that Kingdc-. Proceedings of the Zoological Society of London 1933: 735-851. 
Fournet, J. (1853). Recherches sur la distribution et sur les modifications des charactères de quelques animaux aquatiques du bassin du Rhône. Ann. soc. Agric. Lyon 2(5): 1-120. (not seen, cited by Laurent, 1989a).

Fretey, J. (1987). Les Tortues. Fascicule 44 in Beaufort, $F^{\text {. de (Ed.) }}$ I.ivre Roure des Espèces Menacées en Erance, tome 2, Espèces Marines et I.itlorales Menacées. Secretariat de la Faune et de la Flore, Musćum National d'Histoire Naturelle, Paris.

Frominold, ḱ. (1962). Herpetologische studien in Albanien. Aquarien Terrarien 10(?): $365-370$.

Geldiay, R. (1984). Türkiye'nin ege ve akdeniz kiyilarinda yasayan deniz kaplumbagalarinin (Caretta c. caretta L. ve Chelonia m. mydas L.) populasyonlari ve korunmasi ile ilqili arasticmalar. Doga Bilim Dergisi, Ser. $A_{2}$, Cilt 8 , Sayi 1: $66-15$.

Geldiay, K., Koray, T. and Balik, S. (1982). Status of sea turtle populations (Caretta c. caretta and Chelonia m. mydas) in the northern Medilerranean Sea, Turkey. In: Bjorndal, K. (Ed.), Biology and Conservation of Sea Turties. Smithsonian Institution. Pp. 425-434.

Gramentz, D. (1986a). Loggerhead Turtles at Lampedusa, Italy. Marine Turtle Newsletter $36: 3$.

Gramentz, D. (1986b). Cases of contamination of sea turtles with hydrocarbons. U.N. ROCC INFO No. 17: 1-3. Regional 0il Combating Centre, Manoel lsland, Malta.

Gramentz, D. (1988). Involvement of Loggerhead Turtle with the plastic, metal, and hydrocarbon pollution in the Central Mediterranean. Marine Pollution Bulletin 19(1): 11-13.

Groombridge, B. (1982). The IUCN Amphibia-Reptilia Red Data Book. Part 1, Testudines, Crocodyl ia, Rhynchocephalia. IUCN, Gland, Switzerland and Cambridge, UK.

Groombridge, B. and Luxmoore, R. (1989). The Green Turtle and Hawksbill (Reptilia: Cheloniidae): world status, exploitation and trade. Secretariat of the Convention on International Trade in Endangered species of Wild Fauna and Flora, Lausanne. Pp. i-vi, 1-601.

Groombridge, B. and Whitmore, C. (1989). Marine turtle survey in Northern Cyprus. Marine Turtle Newsletter 47: 5-8.

Gruvol, A. (1931). Les Etats de syrie. (Richesses marines et fluviales. Exploitation actuelle - Avenir). Bibliothèque de la Faune des Colonies Françaises III. Paris, Société d'Editions Géographiques, Maritimes et Coloniales.

Henwood, T.A. (1987). Movements and seasonal changes in Loggerhead Turtle Caretta caretta agregations in the vicinity of Cape Canaveral, Florida (1978-84). Biological Conservation 40: 191-202.

Hornel1, J. (1935). Report on the Fisheries of palestine. Published on behalf of the Government of Palestine by the Crown Agents for the Colonies, Millbank, London.

Hsï, K.J. (1972). When the Medilerranean dried up. Scientific American, Decenber 1972.

IUCN (1988). 1988 IUCN Red List of Threatened Animals. IUCN, Gland, Switzerland and Cambridge, UK.

IUCN/UNE' (1988). The Mediterranean Monk Seal (Reijnders, P.J.H. et al... Eds). IUCN, Gland, Switzerland.

Klemm, C. de (1989). Comments on the report to the Council of Europe on Marine Turtles in the Mediterranean (Legal aspects). Paper T-PVS (89) 20 circulated at 2nd meeting of Group of Experts on Marine Turtles, Strasbourg. 2-3 October 1989.

Kuller, z. (1986). In litt., 23 November. 
Langeveld, M.J. and Sariguil, G. (1989). Sea turtles nesting on beaches of south-cast Turkoy. A preliminary report with emphasis on the protection of the nesting beaches. Society for the Advancenent of Oceanography (SBNo), Amsterdam.

Lanteri, $\Lambda$. (1982). Noto sur un important rassemblement de Caretta caretta (Reptilia, Testudines) au large de la Côte Oranaise. Bull. Soc. Herp. Fr., 23: 63-65.

laurent, L. (1989a). Les tortues marines en Algérie et au Maroc (Méditerranée). Rapport de mission. Centre d'Activités Réeionales pour les Aires Spécialement Protégées. Grecnpeace Méditerranée. 48 pp.

Laurent, L. (1989b). Report on the status of the Mediterrancan Marine Turtle. Presented at ExperL Mecting on the Conservation of Mediterranean Marine Turtles, Nicosia, 4-6 July 1989. RAC/SPA-UNEP/MEDU WG. $1 / 3$.

Laurent, L. (in press). Observations pélagiques de la Caouanne, Caretta caretta (Chelonii, Cheloniidae) en Méditerranécoccidentale. Bulletin de la Société Herpétologique de France.

Laurenl, L., Nouira, S., Jeudy de Grissac, A. and Bradai, M.N. (in press). Les Tortues Marines de Tunisie; premières donnces. Bulletin de la Société Herpétologique de France.

Lescure, J., Delaugerre, M. and Laurent L. (in press). La nidification de la Tortue Lulh, Dermochelys cariacea (Vandelli, 1761) en Méditercanéc. Mésogée.

Lortet, L. (1883). Etudes Zoologiques sur la Faune du Lac de Tibériade Suivies d'un Apercu sur la Faune des Lacs d'Antioche et de Homs. I. Poissons et Reptiles du Lac de Tibériade et de Quelques Autres Parties de la Syrie. Archives du Muséum d:Histoire Naturelle de Lyon, III.

Lortet, L. (1887). Observations sur les Tortues Terrestres et Paludines du Bassin de la Méditerranée. Archives du Muséum d'Histoire Naturelle de Lyon, IV.

Loveridge, A. and Williams, E.E. (1957). Revision of the African tortoises and turtles of the suborder cryptodira. Bulletin of the Museum of Comparative Zoology, Harvard 115(6): $163-557$.

Maldonado, A. (1985). Evolution of the Mediterranean basins and a detailed reconstruction of the Cenozoic paleoceanography. In: Margalef, M. (Ed.). Western Mediterranean. Key Énvironments Series, 'ergamon Pross Ltd. Chapter 2, pp. 17-59.

Mann, T.M. (1977). Impact of developed coastline on nesting and hatchling sea turtles in southeastern Florida. Master's Thesis, Flurida Atlantic University.

Manzella, S.A., Fontaine, C.T. and Schroeder, B.A. (1988). LogEerhead sea turtle travels from Padre Island, Texas to the mouth of the Adriatic Sea. Marine Turtlo Newsletter 42: 7.

Margaritoulis, D. (1980). Nesting of the sca turtles Caretta caretta on 7akynthos Island. Nature: Bulletin of the Hellenic Society for the protection of Nature, Alhens, No. 22: 41-43.

Margaritoulis, D. (2982). Observations on Loggerhead sea Turlle Caretta caretta activity during three nesting scasons (1977-1979) in Zakynthos, Greece. Biological Conservation 24: 193-204.

Margaritoulis, D. (1986). Captures and strandings of the Leatherback sea Turtle, Dermochelys coriacea, in Grecce (1982. 1984). Journal of Herpetology $20(3): 471-474$.

Margariloulis, D. (1987a). Nesting activity and factors affecting breeding of the Logerhead Sea Turt le Caretta caretta (L.) in Greece. Minisiry or the Enviconment, Physical Planning and Public Works, Athens. Hinal Report on contract No. ENV 790-GR.

Margaritoulis, D. (1987b). Monitoring of Loggerhead Sea Turtle nesting in the Bay of Kiparissia, Greoce. Sea Turtle Proteclion Society, Athens. Pp. 1-12, plus figures. 
Margaritoulis, D. (1988a). Post-nesting movements of Loggerhead Sea Turtles taqged in Grecce. Rapports et Procès-Verbaux des Réunions. Condensés des travaux urésentés lors du XXXI Congrès-Assembléc Plénière Athènes (Grècc) volume 31 (2): 284, V-1II3. C.L.E.S.M., Monaco.

Margaritoulis, D. (1988b). Nesting of the Loggerhead sea Turtlc Caretta caretta on the shores of Kiparissia bay, Greece, in 1987. Mésogée 48: 59-65.

Margaritoulis, D., Arapis, T., Kornaraki, E. and Mytilineou, C. (1986). Three specimens of the Green Sea Turtle Chelonia mydas (L.) recorded in Greece. Biologia Ga1lo-hellenica 12: 237-243.

Marinos, P. (1981). On the distribution of sea turtles in Greek waters. Marine Turtle Newsletter 19: 13-14.

Marinos, P. (1982). Final Report. WWE/IUCN Project No. 1822. Grecce, Sea Turtle Conservation, 1sland of Zakynthos.

Mayol, J. and Castello Mas, M. (1983). Contribucion al conocimiento de la Tortuga Boba en las Baleares. Ministerio de Agricultura, pesca y Alimentacion. ICONA, l'alma de Mallorca.

Mertens, R. (1959). Zur kenntnis der lacerten auf der Insel Rhodos. Senckenbergiana biologica $40(1 / 2): 15-24$.

Mortiner, J.A. (1982). Factors influencing beach selection by nesting sea turtles. In: Bjorndal, K. (Ed.), Biology and Conservation of Sea Turtles. Smithsonian Instilute. Pp. 45-51.

Mrosovsky, N. (1983). Conserving Sea Turtles. The British Herpetological Society, London. $176 \mathrm{pp}$.

Ogren, L. and McVea, C. (1982). Apparent hibernation by sea turtles in North American waters. In: Bjorndal, K. (Ed.), Biology and Conservation of Sea Turtles. Smithsonian Institute. Pp. 127-132.

Palma, M.G. di (1978). Notizie sulle tartarughe marine in sicilia (Reptilia, Testudines). Il Naturalista siciliano (4th ser.) 2(1-2): 1.6.

Panou, A. and Moschonas, S. (1990). Incidental catches of Loggerhead turtles Caretta caretta in swordrish long lines in the Ionian Sea, Grecce.

Pérès, J.M. (1985). History of the Mediterranean biota and the colonization of the depths. In: Margalef, M. (Ed.), Westorn Mediterranean. Key Finvironments Series, Pergamon Press Ltd. Chapter 7, pp. 198-232.

Pritchard, P., et al .; Bjorndal, K. and Balazs, G.H. (Eds) (1983). Manual of sea turtle research and conservation techniques. Second edition. Centre for Environmental Education, Washington, D.C.

Ramsey, A.I.G. (1970). A search for the Green Turtles of the South Turkish coast, 1970 (with comment on cyprus). Unpublished report subnitted to the Fauna and Filora Preservation Society.

Raymond, P.W. (1984). Sea turtle hatchling disorientation and artificial beachfront lighting. Centre for Environmental Education, Washinglon D.C.

Sarigiil, G. (1989). Reporl to Council of Europe Experts Mecting on marine turtles, 2-3 october 1989 , Strasbourg. 6 pp.

Schleich, H.-H. (1984). Studies on the herpetology of Kouf National park and adjacent areas of Cyrenaika. Final Report, Projecl 9041. IUCN, Gland, Switzerland.

Shabica, S.V. (1982). Planning for protection of sea turtle habitat. In: Bjorndal, K. (Ed.), Biology and Conservation of Sea Turtles, Smilhsunian institution. Pp. 513-518.

Sutherland, J.M. (1984). Report on the biology and conscrvation of the Loeferhead Turtle Caretta caretta, from the Greck Is land 7akynthos. Unpublished report.

Sutherland, J.M. (undaled). Marine Turtle research project. Ionian Islands, Grecce. 1987 season. Unpublished report.

Thibault, J.-C., Delaugerre, M. and Noblet, J.-F. (1984). Livre Rouge. des Vertébrés Menacés de la Corse. Parc Naturel Régional de la Corse. Ajaccio. 
Van den Berk, V.M., Langeveld, M.J. and Sarigül, G. (1988), Cbservations of Cheloniidae and Trionychidae along the Cukurova coast, soutresn Turkey, Spring 1986 and 1987. In: Van der Have et al.. (kds), South Turkey Project. A survey of waders and waterfowl in the Cukurova ds thas, spring 1987. DHKD and WIWO, WIWO Report No. 22. Chapter 13, pp. $1 \leqslant 1-111$.

Van Nierop, M.M. and Den Hartog. J.C. (1984). A sludy on the edt contents of five juvenile Loegerhead turlles, Caretta caretta (Linnacus) 'Reptilia, Chelonildae), from the south castern part of the North At lar: ic Ocean, with emphasis on coclenterate identification. Zoologische Meded ngen $59(4)$ : 35- 54.

Venizelos, L. (1986). Guest editorial: Greek Loggerheads face dangers. Marine Turtle Newsletter 39, p. 1.

Venizelos, L. (1987). Unpublished report prepared for 1 st mes:ing of Group of Experts on Caretla caretta and Chelonia mydas (Bern Convent:ca). 1-2 september, strasbourg.

Venizolos, L. (1988). Report released at Press Conference at ie office of the Hellenic Society for the protection of Nature, Athens, 12 July 1988.

Venizelos, L. (1989). Unpublished report. Zakynthos, 28 Augus 1989.

Voesenck, L.A.C.J. and van Rooy, P.T.J.C. (1984). Herpetolog: 1 Research on Eastern Sardinia: Proposal for a Biogenetic Reserve. Unput shed report to the Council of Europe. Rescarch Institute for Nature Manage-ent, Arnhem; Dept. Of Animal Ecology, Catholic University, Nijmegen; Socictas Éuropaea Herpetologica.

Whitmore, C., Sarigül, G, and Yazgan, N. (in press, 1990). Nei legislation to protect sea turtle nesting areas in Turkay at Patara, the Gčsu Delta and Ekinchik. Marine Turtle Newsletter.

Wilham, R. (1982). Discuption of Sea Turtle habitat with emphesis on human influence. In: Bjorndal, K. (Ed.), Biology and Conservation je sea Turtles, Smithsonian Institution. Pp. 519-522.

Witham, R. (1985). Managing Florida (U.S.A.) Sea Turlle popuzstions. Proceedings of the Symposium on Endangered Marine Animals ac. Marine Parks. Cochin, India. 12-16 January.

Worth, D.F. and Smith, J.B. (1976). Marine turtle nesting on Futchinson Island, Florida, in 1973. Florida Marine Research Publicat: : 18: 1-17. 
Sales agents for publications of the Council of Europe

Agents de vente des publications du Conseil de l'Europe

AUSTRALIA/AUSTRALIE

Hunter Publications

58A. Gipps Street

AUS-3066 COLLINGWOOD. Victoria

AUSTRIA AUTRICHE

Gerold und Co.

Graben 31

A-1011 VIENNA 1

BELGIUM BELGIQUE

La Librairie européenne S.A.

244. rue de la Loi

B-1040 BRLSSELS

\section{CANADA}

Renouf Publishing Company Limited 1294 Algoma Road

CDN-OTTAWA ONT K1B 3 W8

\section{CYPRUS CHYPRE}

MAM

The House of the Cyprus Book

P.O. Box 1722

CY-NICOSIA

\section{DENMARK DANEMARK}

Munksgaard

Book and Subscription Service

P.O. Box 2148

DK-1016 COPENHAGE $: K$

\section{FEDERAL REPUBLIC}

OF GERMANY /

RÉPUBLIQUE FÉDÉRALE

D'ALLEMAGNE

Verlag Dr. Hans Heger

Herderstraße 56

Postfach 201363

D-5300 BONN

\section{FINLAND FINLANDE}

Akateeminen Kirjakauppa

Keskuskatu 1

P.O. Box 128

SF-00101 HELSINKI

\section{GREECE / GRÈCE}

Librairie Kauffmann

28 , rue Stadiou

GR-ATHENS 132

\section{ICELAND ISLANDE}

Bókabúd Máls og menningar

Laugavegi 18

IS-REYKJAVIK 101

\author{
IRELAND / IRLANDE \\ Government Stationery Office \\ Publications Section \\ Bishop Street \\ IRL-DUBL IN 8
}

ITALY / ITALIE

Libreria Commissionaria Sansoni

Via Benedetto Fortini, 120/10

Casella Postale 552

I-50125 FLORENCE

LLXEMBOURG

Librairie Bourbon

(Imprimerie Saint-Paul)

11. rue Bourbon

L-1249 LUXEMBOURG

MALAYSIA/MALAISIE

Library Building

Lniversity of Malaya

P.O. Box 1127

Jalan Pantai Baru

59700 KUALA LUMPUR

$\triangle E T H E R L A N D S / P A Y S-B A S$

InOr-publikaties

Noorderwal 38

Postbus 14

NL-7240 BA LOCHEM

NEW ZEALAND

NOUVELLE-ZÉLANDE

Government Printing Office

Mulgrave Street

(Private Bag)

NZ-WELLINGTON

NORWAY / NORVĖGE

Akademika, A/S Universitetsbokhandel

P.O. Box 84

Blindern

N.0314 OSLO

\section{PAKISTAN}

Tayyab M.S. Commercial Services

P.O. Box 16006

A-2/3. Usman Ghani Road

Manzoor Colony

PAK-KARACHI-44

PORTUGAL

Livraria Portugal

Rua do Carmo. 70

P-1200 LISBON
SPAIN / ESPAGNE

Mundi-Prensa Libros S.A.

Castelló 37

E-28001 MADRID

Libreria de la Generalitat

Rambla dels Estudis, 118

E-08002 BARCELONA

SRI LANKA

Centre for Curriculum Advancement 78 Eachamottai Road CL-JAFFNA

SWEDEN/SUÈDE

Aktiebolaget C.E. Fritzes

Regeringsgatan 12

Box 16356

S-10327 STOCKHOLM

SWITZERLAND / SUISSE

Buchhandlung Heinimann \& Co.

Kirchgasse 17

CH-800I ZURICH

Librairie Payot

6 , rue Grenus

CH-1211 GENEVA 11

TAIWAN - HONG KONG

SINGAPORE / SINGAPOUR

Mappamundi Taiwan

7 FI. 258, Nanking E. Rd.

Sec. 3 Taipei

TAIWAN R.O.C.

TURKEY / TURQUIE

Librairie Haset Kitapevi A.S.

469 , Istiklâl Caddesi

Beyoglu

TR-ISTANBUL

UNITED KINGDOM/

ROYAUME-UNI

HMSO

Agency Section

51 Nine Elms Lane

GB-LONDON SW8 5DR

UNITED STATES and CANADA /

ÉTATS-UNIS et CANADA

Manhattan Publishing Company

1 Croton Point Avenue, P.O. Box 650

CROTON, N.Y. 10520

\section{STRASBOURG}

Mésange S.A.

Groupe Berger-Levrault

23, place Broglie

F-67081 STRASBOURG Cedex 


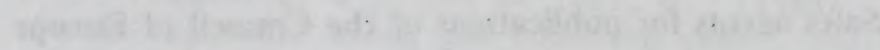

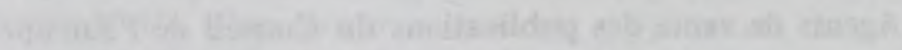

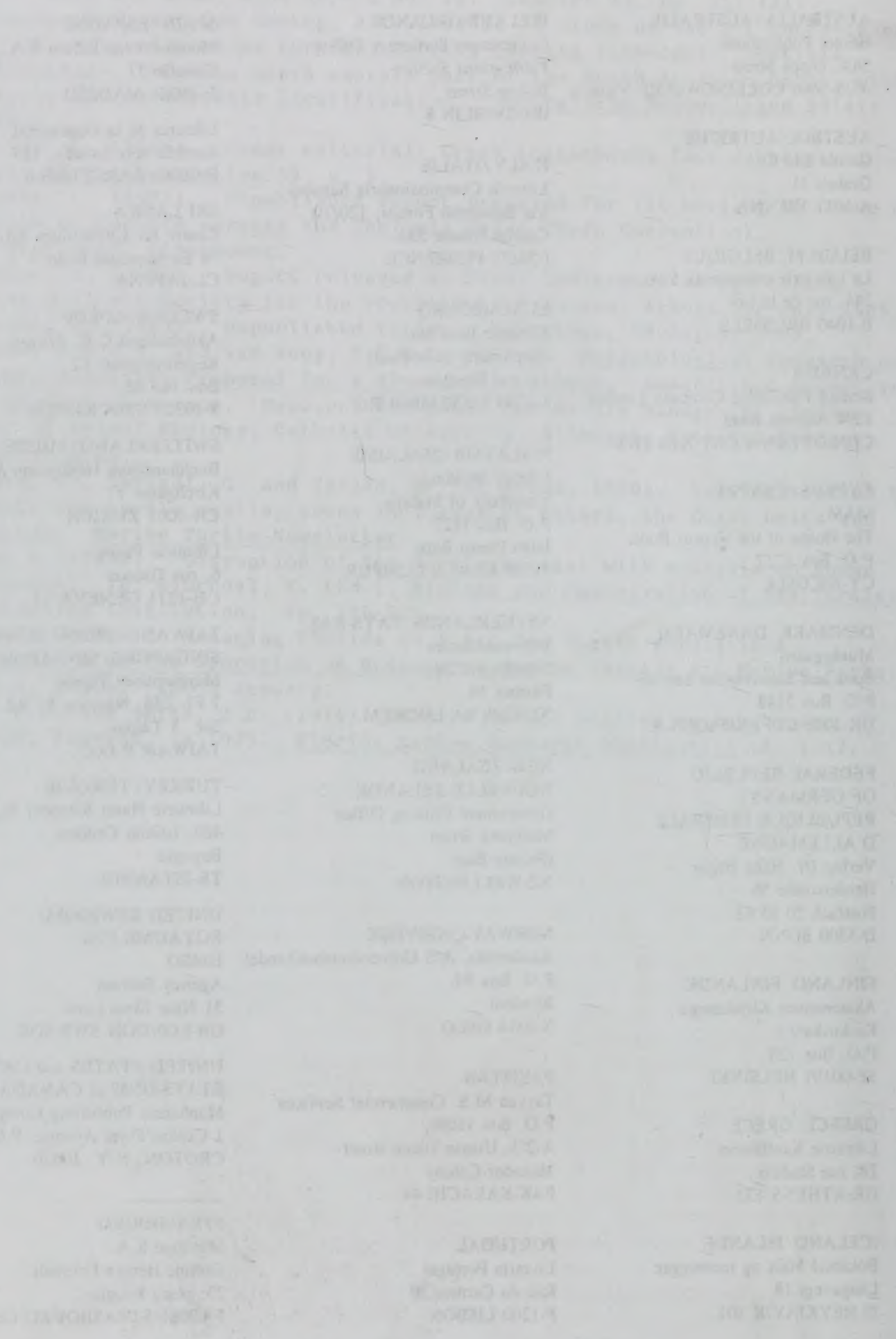


